\title{
The 1979 Archaeological Survey of Portions of the Choke Canyon Reservoir in Live Oak and McMullen Counties, Texas
}

Erwin Roemer Jr.

Center for Archaeological Research

Follow this and additional works at: https://scholarworks.sfasu.edu/ita

Part of the American Material Culture Commons, Archaeological Anthropology Commons, Environmental Studies Commons, Other American Studies Commons, Other Arts and Humanities Commons, Other History of Art, Architecture, and Archaeology Commons, and the United States History Commons

Tell us how this article helped you.

This Article is brought to you for free and open access by the Center for Regional Heritage Research at SFA ScholarWorks. It has been accepted for inclusion in Index of Texas Archaeology: Open Access Gray Literature from the Lone Star State by an authorized editor of SFA ScholarWorks. For more information, please contact cdsscholarworks@sfasu.edu. 


\section{The 1979 Archaeological Survey of Portions of the Choke Canyon Reservoir in Live Oak and McMullen Counties, Texas}

\section{Creative Commons License}

\section{(c) (1) \&}

This work is licensed under a Creative Commons Attribution-NonCommercial 4.0 International License 


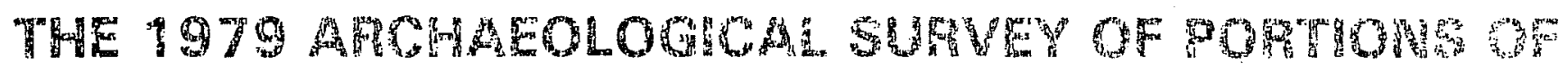
THE CHOKE CANYON AESEPVOR IN LVE OAK AWH MCMULLEN COUNTHE. TRXAS

\section{By}

Erwin Roemer, ar.

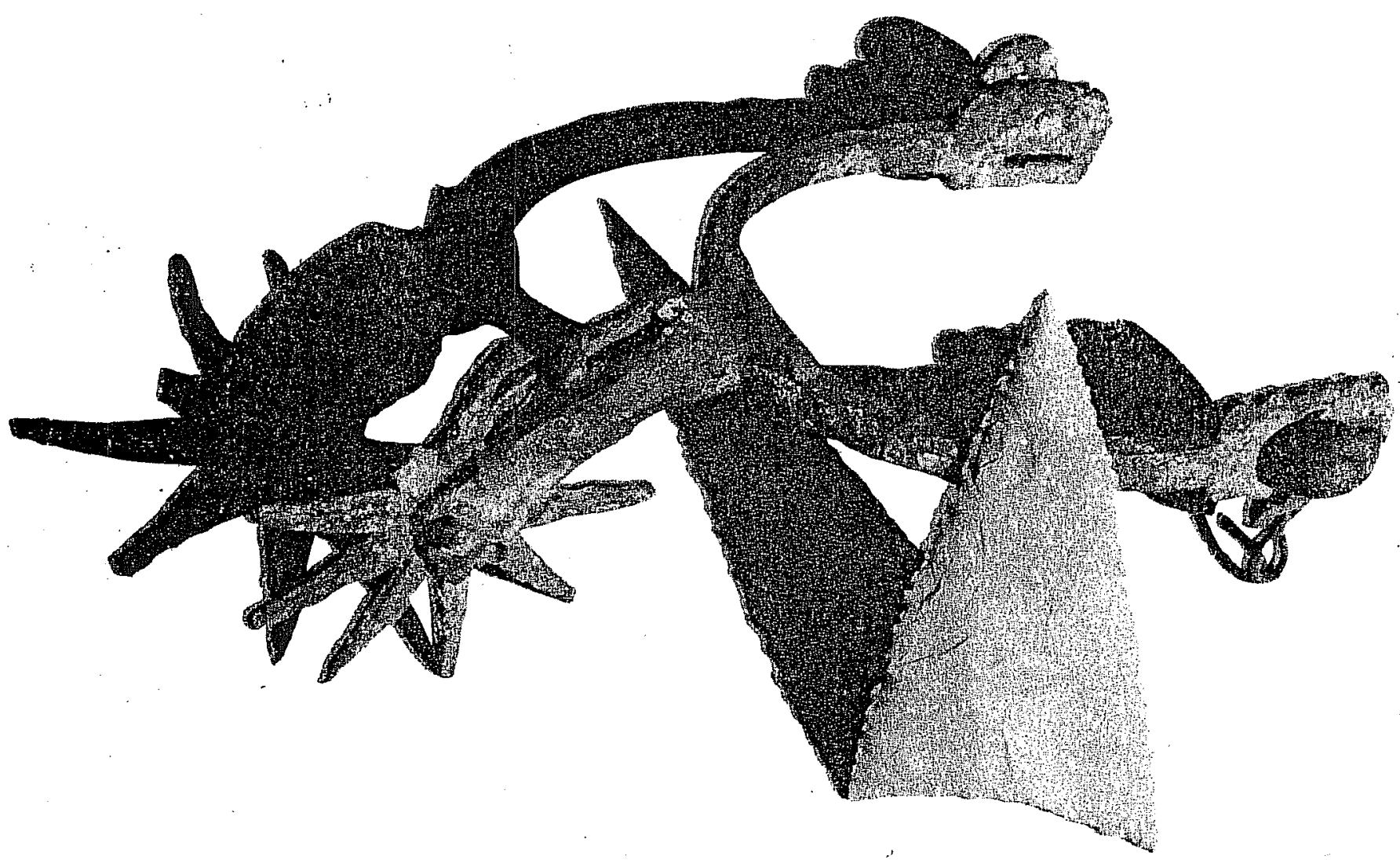

Center for Archaeological Research

The University of Texas at San Antonio

Choke Canyon Series: Volume 4 

THE 1979 ARCHAEOLOGICAL SURVEY OF PORTIONS OF

THE CHOKE CANYON RESERVOIR IN LIVE OAK AND

MCMULLEN COUNTIES, TEXAS

Erwin Roemer, ur.

Center for Archaeological Research

The University of Texas at San Antonio

Choke Canyon Series: Volume 4

1981 



\section{Center for Archaeological Research \\ The University of Texas at San Antonio}

78285

Thomas R. Hester, Director

Volumes in the Phase I Choke Canyon Series.

Volume 1 Historic Indian Groups of the Choke Canyon Reservoir and Surrounding Area, Southern Texas. By T. N. Campbe11 and T. J. Campbe11.

Volume 2 Part I - Historical Resources of the Choke Canyon Reservoir Area in McMullen and Live Oak Counties, Texas. By Dianna Everett.

Part II - Historical Archaeological Resources of the Choke Canyon Reservoir Area in McMullen and Live Oak Counties, Texas. By Philip A. Bandy.

Volume 3 An Archaeological Survey of a Portion of the Choke Canyon - Reservoir Area in McMullen and Live Oak Counties, Texas. By Alston V. Thoms, John L. Montgomery, and Alice W. Portnoy.

Volume 4 The 1979 Archaeological Survey of Portions of the Choke Canyon Reservoir in Live Oak and McMullen Counties, Texas. By Erwin Roemer, Jr.

Volume 5 Archaeological Investigations at Choke Canyon Reservoir, South Texas: The Phase I Findings. By Grant D. Hal1, Carol Graves, and Stephen L. BTack.

Volume $6 \quad$ Archaeological Testing and Collecting at Choke Canyon Reservoir, Nueces River Project, Texas. By Carol S. Weed and Harry J. Shafer.

Volume 7 Excavations at 41 LK 67, A Prehistoric Site in the Choke Canyon Reservoir, South Texas. By Grant D. Hal1.

Volume 8 Excavations at Sites 41 LK $31 / 32$ and 41 LK 202 in the Choke Canyon Reservoir, South Texas. By Robert F. Scott IV and Daniel E. Fox.

Volume 9 Phase I Archaeological Investigations at Choke Canyon Reservoir, South Texas: A Summary and Synthesis. By T. R. Hester and Grant D. Ha11.

NOTE: Titles of the above volumes are only tentative and may change at time of publication. 



\section{ABSTRACT}

The Center for Archaeological Research, The University of Texas at San Antonio, conducted an intensive surface survey aimed at location and evaluation of cultural resources in portions of the Choke Canyon Reservoir in Live Oak and McMullen Counties, Texas. The survey was conducted between May and September 1979. The area examined consists of approximately 8400 acres ( 3400 hectares) located in areas not previously available for survey. A total of 94 archaeological sites, 86 low density scatters, and 20 isolated finds was recorded. This total includes 16 historic sites or. site components and 14 sites containing Late Prehistoric materials. The remaining prehistoric sites are either Archaic or of an unidentified cultural period. A total of 32 sites is recommended for further field evaluations. Site recording and preliminary evaluation took precedence, and minimal artifact collections were made. The previous work in the area by the Texas Historical Commission and Texas Tech University strongly influenced survey methodology and evaluation. Concluding interpretations present a discussion of the current state of settlement system investigations and an affirmation of the basic cultural models presented by earlier workers. 

TABLE OF CONTENTS

Page

ABSTRACT ..............................

LIST OF FIGURES ................................. iv

LIST OF TABLES. . . . . . . . . . . . . . . . . . iv

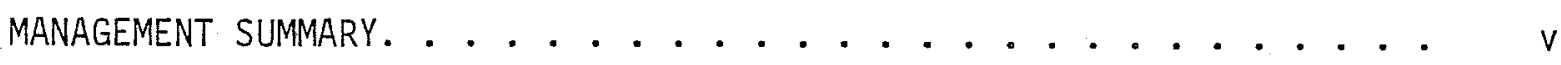

INTRODUCTION. . . . . . . . . . . . . . . . . . . . . 1

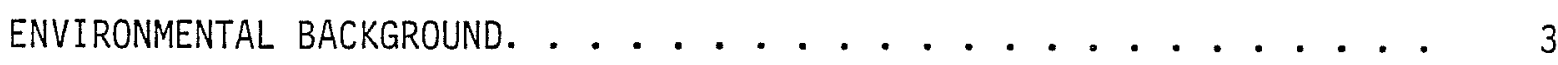

ARCHAEOLOGICAL BACKGROUND ....................... 6

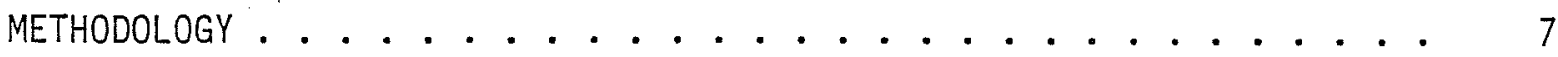

STUDY AREAS ........................................ 11

ADDITIONAL STUDY AREAS .............................. 24

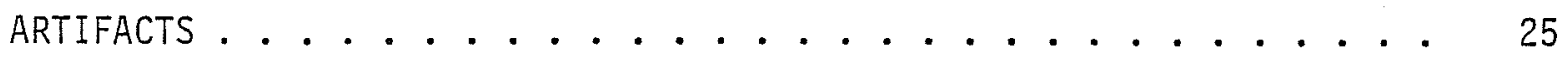

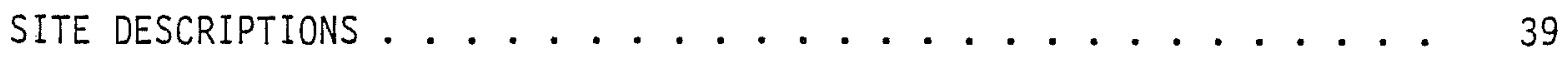

Site Descriptions: Prehistoric. . . . . . . . . 39

Site Descriptions: Historic . . . . . . . . . 73

LOW DENSITY SCATTERS. . . . . . . . . . . . . . . . . . 80

REVISITED SITES ................................ 85

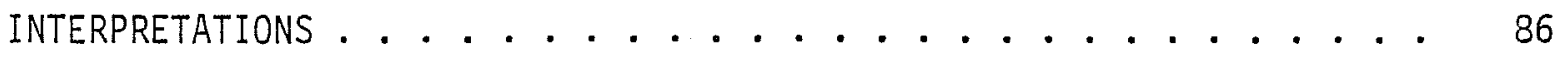

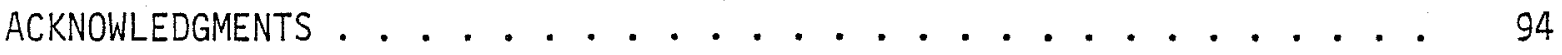

REFERENCES CITED. . . . . . . . . . . . . . . . 95

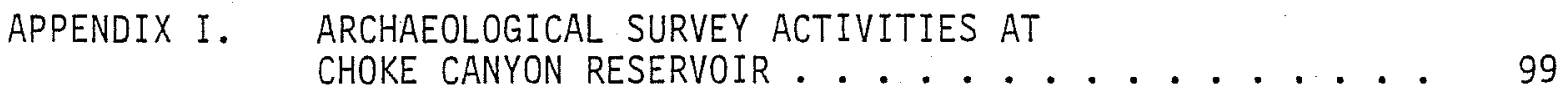

APPENDIX II. FIELD FORMS. . . . . . . . . . . . . 101

APPENDIX III. SCOPE OF WORK. .............. 106 


\section{LIST OF FIGURES}

Figure

Page

1. Choke Canyon Archaeological District, Areas Surveyed by CAR-UTSA 1979 ..................... . . . . 2

2. Sites Recorded in Study Areas. 1 and $2 \ldots 12$

3. Sites Recorded in Study Area 3............... . 14

4. Sites Recorded in Study Area 4 . . . . . . . . . . . . 16

5. Sites Recorded in Study Area 5 and Playa Area . . . . . . . . 18

6. Sites Recorded in Study Areas 6, 7, and Jambers' Property.................. 20

7. Sites Recorded in Study Area 8 . . . . . . . . . . 22

8. Study Areas 4 and 5 ................... . . . 41

9. Study Area 2 . . . . . . . . . . . . . . . . . . 43

10. Study Areas 1 and 3....................... 45

11. Study Area 8 . . . . . . . . . . . . . . 56

12. Study Area 7 . . . . . . . . . . . . . . . 64

13. Examples of Field-Sketched Artifacts . . . . . . . . 65

14. Study Areas 6 and 7 . . . . . . . . . . . . . 70

15. Sketch of Yarbrough Cemetery Gravestones . . . . . . . . 87

$$
\text { LIST OF TABLES }
$$

Table

Page

1. Materials Observed at Prehistoric Sites . . . . . . . 26

2. Tentative Cultural-Chronological Affiliations Based on

Diagnostic Artifacts. . . . . . . . . . . . . 30

3. Low Density Scatter Descriptions . . . . . . . . . . . 80

4. Isolated Finds .................. . . . 84 


\section{MANAGEMENT SUMMARY}

In 1979, the Center for Archaeological Research (CAR), The University of Texas at San Antonio (UTSA), under contract (No. 5B-V0527), with the United States Department of the Interior, Bureau of Reclamation (BOR) carried out a survey of 10,500 acres in the Choke Canyon Reservoir area. The survey was undertaken to complete archaeological documentation and preliminary evaluation of previously unexamined areas. The majority of the reservoir area had been investigated in two earlier surveys: a survey in 1974 and 1976 of 27,000 acres by the Texas Historical Commission, and a 1977 survey of 6000 acres by Texas Tech University, under subcontract with CAR-UTSA.

The scope of work followed guidelines provided by the BOR solicitation (January 1979) and the CAR-UTSA Draft Recommendations (November 1978). Techniques of intensive field examination were utilized, and evidence was recorded in a compatible manner. The reader should refer to the METHODOLOGY section of this publication for details such as site definition. A crew of four performed the field work in 8.5 work weeks between May and September 1979. This was actually a six-week period, followed by additional survey due to acreage re-estimates, provided by the contract modification. For budgetary information see Appendix I; comparison of time, money, and area surveyed is also provided.

The difficulty of gaining access to property constituted the major limitation on the CAR survey. Coordination with the BOR representatives in Three Rivers helped the situation, but certain locations have not been surveyed at this writing: properties NR-94, NR-98, and NR-115. Funding for future examination of these areas has been retained. The adjusted acreage surveyed is therefore ca. 9790 acres (3962 hectares). It may be noted that the figure used for the totaled area in both the ABSTRACT and the STUDY AREAS section is less than 9790 acres; this discrepancy reflects a difference in lab estimation techniques. Conservative use of an acreage estimator grid was employed on USGS (1:24000inch) maps in the CAR lab; a planimeter instrument was the source of the final BOR (Three Rivers) estimate. Another limitation on the survey was surface visibility, usually related to the dense vegetation of late spring and summer.

Data relating to a total of 94 archaeological sites, 86 low density scatters, and 20 isolated finds are compiled in this report. Of the sites, 32 have been recommended for further evaluation. The total site inventory involves 78 prehistoric sites and 16 sites with additional or solely historic traits. Prehistoric sites typically display burned rocks, stone tools and chipping debris, mussel shells, and land snails. Ground stone artifacts, potsherds, and animal bone remains occur less often. Most historic evidence consists of structural remnants, such as collapsed stone chimneys, and scatters of glass, pottery, and metal fragments. There are many sites displaying good potential for information in the quality of material and preservation.

A11 records, maps, and artifacts are stored at the Center for Archaeological Research, The University of Texas at San Antonio. Duplicate site forms and map locations are available at the Texas Archeological Research Laboratory, Austin. The BOR offices in Amarillo and Three Rivers have site information, with the latter possessing plotted 1:800-inch project maps. 
Al1 Choke Canyon Reservoir sites will receive some type of negative impact. Brush clearing will disturb many sites; silting, underwater currents, wave action, and potential chemical changes in the inundated soils will have an effect, while fluctuation in the reservoir level will decrease stability. Increased human activities within the project area will also result in more relic collecting in recreation areas and adjacent land not covered by this survey. 


\section{INTRODUCTION}

These investigations were formulated in response to the United States Bureau of Reclamation Solicitation No. 5B-V0527, calling for an archaeological survey of specific areas in the Choke Canyon Reservoir. Intensive surface examination, designed to locate, record, and evaluate all cultural resources, was carried out within approximately 10,500 acres (4249 hectares) in Live Oak and McMullen Counties (Fig. 1). This is an estimated 10 percent of the reservoir area that had not been included in earlier surveys due to access problems. A subsequent modification of the solicitation allowed additional areas to be covered:

The reservoir area is ca. $27.2 \mathrm{~km}$ east-west along the Frio River channel, from near Three Rivers to Tilden, Texas. North-south width varies according to the distance between valley walls. The 233 foot elevation (msl) is considered the maximum flood pool level floodline and usually constituted the survey limits. The region lies within the Rio Grande Plain of southern Texas.

Cultural evidence is known from Paleo-Indian times to the present. Most sites in Choke Canyon are representative of the Archaic and Late Prehistoric periods, with the majority of historic evidence dating after the 1850s.

Detailed scope of work and budget information may be found in Appendix I. Approximately 8400 acres* (3400 hectares) were intensively surveyed in 159 person days (for a comparison to previous surveys, see Appendix I). Field work was from May 7 to June 14 and August 20 to September 5 , 1979. The crew numbered four persons for six weeks, and three persons for the remainder of the time. Erwin Roemer was field director, with crew members Curtis Dusek, Paul Lukowski, Robert Stiba, and Don. White. Grant D. Hal1, field supervisor, joined the survey activity on at least seven occasions.

A total of 94 sites was recorded: 78 prehistoric and 16 historic or multicomponent sites. Prehistoric sites consist primarily of burned rock scatters, stone tools and debitage, mussels, and land snails. Site depth is generally under one meter, and often shallow or eroded. Many sites have evidence of Late Archaic or Late Prehistoric occupations. Prehistoric site locations and low density scatters are well distributed throughout the reservoir, and often relate to drainages. Historic sites frequently display stone structural traces with associated pottery, glass, and metal debris. These were often in the Yarbrough Bend area of the Frio River, and date from the 1850 s and later.

Examination and recording techniques follow specifications as set forth in Solicitation No. 5B-V0527. Intensive survey and site definitions were designed to be compatible with the Texas Tech University survey (Thoms, Montgomery, and Portnoy 1981).

*Conservative figure based on CAR grid estimation; unavailable land discussed in MANAGEMENT SUMMARY is not included. 


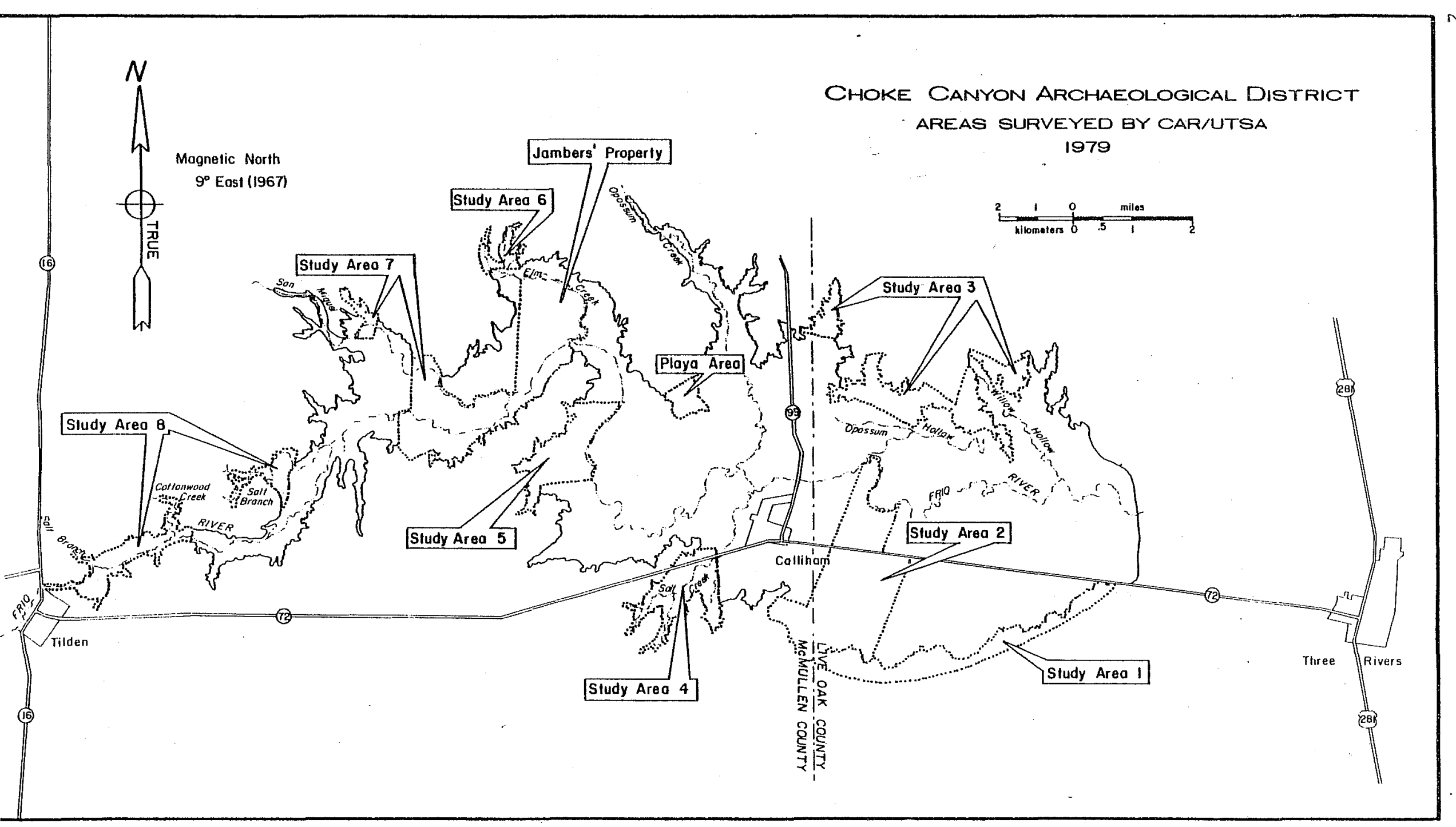

Figure 1. Choke Canyon Archaeological District, Areas Surveyed by CAR-UTSA 1979. 
A11 archaeological resources in the Choke Canyon Reservoir area may be detrimentally affected by brush clearing, construction, inundation, and increased relic collecting.

The Center for Archaeological Research, The University of Texas at San Antonio, is the repository for this survey's documents, maps, and artifacts, as well as those of related Choke Canyon studies.

For the purposes of this report, background discussions are necessarily brief. The reader is referred to previous summaries by Lynn, Fox, and O'Malley (1977) and Thoms, Montgomery, and Portnoy (1981).

\section{ENVIRONMENTAL BACKGROUND}

Substantial environmental information for the archaeological resources of Choke Canyon was compiled in reports of Lynn, Fox, and O'Malley (1977) and Thoms, Montgomery, and Portnoy (1981). Much of the following summarizes this research and related primary references.

The general setting is usually termed the Rio Grande Plain, the area of Texas south of San Antonio. Relatively gentle topography exists from the southeastern margin of the Edwards Plateau (near San Antonio) to the coast, dropping about 1000 feet in the course of $150 \mathrm{miles}$. The Nueces, Frio, and Atascosa Rivers comprise the major regional drainages to the coast. Greater topographic relief is seen in the southwestern area along the Rio Grande.

The Choke Canyon Reservoir is located on the Tower Frio River just above its confluence with the Atascosa River. The lake will extend upstream (west about 17 miles) to Tilden, Texas. This area encompasses the northwestern portion of Live Oak County and northeastern McMullen County. Area elevation varies from about 350 feet maximum (msl) near Tilden, to less than 150 feet on the floodplain near Three Rivers. The reservoir's maximum flood level is predicted to be the 233-foot contour elevation; average water level is predicted at the 220 -foot elevation.

The study area is underlain by Tertiary sedimentary strata, gently dipping southeastward. There are three formations--the Fayette, the Frio, and the Catahoula--outcropping respectively in the western, central, and eastern portions of the reservoir.

The Eocene Fayette formation is the oldest, a part of the Jackson strata group of Texas, and it consists mainly of unconsolidated and consolidated sand and clays. Volcanic and marine activity influenced these deposits. Further division into two units termed Whitsett (upper) and Lipan (1ower) is known. An aspect that may have archaeological importance, in terms of resource utilization, is that the Whitsett member exhibits resistant sandstone beds located in the western reservoir area, as in the vicinity of Skillet Mountain.

The second formation, the 0ligocene Frio, is mainly clay, often with 
gypsum. It shows between the Fayette and Catahoula in a relatively smal1 area.

The Miocene Catahoula formation consists of tuff, with mixtures of sand and clay. Sandstone beds and various soils are exhibited. A cuesta or low escarpment, known as the Bordas-0akville-kisatchie, curves northeast to southwest with the Catahoula, causing the drainage constriction or "choke" near Three Rivers.

More recent Quaternary deposits are seen as the alluvial clay, sand, and gravel of the Frio River system. Modern soil types are numerous, and information has been obtained from the USDA office in Tilden by CARUTSA.

Much surviving evidence of the cultural past consists of 1 ithic tools and by-products made of raw material resources found in the local geologic formations. Sandstone was used by prehistoric people for abrading, food processing, tool making, and in hearth construction. Catahoula tuff also occurs in prehistoric hearths. Sandstone was a major constituent used in construction of 19th century historic homesteads. Late Tertiary deposits termed Uvalde gravels are important prehistoric raw materials in the Choke Canyon area. A good discussion is found in Creel et al. (1979:4-5). Abundant small cobbles of chert, silicified wood, and quartz supplied most of the tool-making and hearth stone material.

Geological material and fluvial processes of the Frio River system have created the basic physiographic designations used in this study. These are the floodplain, Pleistocene terrace, valley wal1, and upland areas. The floodplain takes in most of the survey area. This includes the active Frio River channel, affiliated drainages, and higher seasonal floodplains. Alluvial soil here is mainly clay with some sand and silt. Pleistocene terrace remnants exist in certain locations, denoted by more gravel and redder clay. The 233-foot contour generally is at the valley walls. Gradient varies from the Uvalde gravel-laden siopes of Live Oak County to the abrupt sandstone bluffs along portions of Yarbrough Bend. Upland areas, rolling plains above the river valley, were seldom surveyed, as they were out of the reservoir limits. However, portions were examined where State Highway 72 was rerouted along the upland strip separating the Nueces and Frio Rivers.

The Rio Grande Plain usually has hot summers and mild winters, with most rainfall occurring in the spring and fall. The Thornwaite (1948) classification considers the area megathermal and semiarid. Temperatures sometimes go below freezing in the winter and may reach $100^{\circ} \mathrm{F}$ in the summer. Typical1y daily mean temperatures are in the $50^{\circ} \mathrm{F}$ range for January and the $80^{\circ} \mathrm{F}$ range for July. Precipitation amounts fall well behind rates of evaporation. Figures available from the U.S. Department of Commerce Tilden Station (No. 20-41) show an annual rainfall average of 23.08 inches $(57.7 \mathrm{~cm}$ ), with annual evaporation at about 59 inches $(147.5 \mathrm{~cm})$. The Gulf system of humid, southeasterly winds usually dominates, having seasonal occlusions with northern Canadian fronts. Rainfall varies from year to year, with drought periods and hurricanes causing radical extremes in rainfall 
averages. The Frio River and its tributaries, such as San Miguel and Opossum Creeks, provide modern perennial water supplies. Many other tributaries and flood channels contain temporary water.

Only rudimentary information exists on the paleoenvironment of the area. It is generally believed that Late Pleistocene environments were more mesic compared to the present. This reconstruction is based largeiy on pollen studies such as Bryant and Larson (1968) and Bryant and Shafer (1977). Recent research in this field may result in more precise viewpoints (cf. Gunn and Mahula 1977).

Plants and animals of the region are included in the Tamaulipan Biotic Province of Blair (1950, 1952), which is savannah with desert grasses and mesquite. There are two major vegetational patterns. River bottoms or other substantial drainages display trees such as oak, hackberry, and elm, with vines, mosses, forbs, and grasses. Thorn brush and grassland exist up from these areas, including mesquite, whitebrush, native grasses, persimmon, agarita, soapbush, acacias, mimosas, cacti, and yucca. Botanists Johnston and Darr (1977:247-255) have conducted Timited vegetational surveys at Choke Canyon. Vegetation has apparently changed through the distant and recent past in southern Texas. A "parkland" Pleistocene has been proposed by Bryant (1966). In post-Pleistocene times, greater aridity suggests more grassland and fewer trees. Dramatic vegetational change is known to have occurred during the Historic period. Thoms, Montgomery, and Portnoy (1987) also provide a good discussion of the area. Brush has now replaced native grasses to such an extent that early historical observations no longer seem valid (Hester 1980b). During the Prehistoric period, fires appear to have aided brush control, and prairie grasses maintained substantial stands. Ang10-European fencing and overgrazing encouraged by droughts in the late 1800s, are prime reasons why brush is now so thick and dominant. Today, pastures reclaimed from the brush and planted with imported grasses recreate on a small scale what may have been the former appearance of prairie areas. Specific aspects of vegetation and physiography are explained in the SITE DESCRIPTIONS section.

Fauna of the Choke Canyon area are numerous. Common animal include the deer, peccary, bobcat, turkey, quail, dove, owl, coyote, squirrel, cottontail and jackrabbit, raccoon, opossum, fox, skunk, armadi110, rodent, turtle, snake, and fish. Recently extinct animals are the buffalo, antelope, wolf, jaguar, and bear. Alligators and mountain lions rarely occur. With minor exceptions (such as the armadil10, which came into the area in the mid-19th century), al1 wildlife was probably of some use to the prehistoric inhabitants of Choke Canyon. 


\section{ARCHAEOLOGICAL BACKGROUND}

A tentative chronological-cultural framework for southern Texas has been established. This brief review employs four main divisions (Hester 1980a, 1980b).

Paleo-Indian: (ca. 9200-6000 B.C.) Evidence in Live Oak and McMullen Counties is often in the form of isolated Clovis, Folsom, Plainview, Scottsblu6f, Golondrina, and Angostura type projectile points. These represent a technologically specialized hunting and gathering lifeway.

Archaic: (ca. 6000 B.C.-A.D. 1200) This period covers a long time span, with early, middle, and late segments that are largely distinguished by different point forms such as Bulverde, Frio, and Ensor. The Archaic is wel1 represented in the reservoir area, with numerous sites exhibiting hearths, chipped stone artifacts, mussel and snail utilization, etc., (see Hester 1980b for a summary of the South Texas Archaic).

Late Prehistoric: (ca. A.D. 1200-1600) This time period is represented by arrow points such as Scallorn and Perdiz, and aboriginal pottery. These traits are now well recognized in the area (Hester 1980b). The huntinggathering mode of existence probably had much in common throughout these three major periods of prehistory, but each period is distinguished by certain forms of material culture (Hester 1976a:83).

Historic: (A.D. 1600 to present) This period relates to European contact. The aborigines have been termed Coahuiltecans, now considered to be an overgeneralization (Campbel1 and Campbel1 1981). Spanish occupation is not documented in the study area, but several major trails passed nearby. Besides missionary activities, pressure from Apaches probably caused instability for the Coahuiltecans here. Occasional travelers, fringe ranching operations, and wild cattle and mustangs were possibly the only effects of "civilization" before 1823. After that time, a colonization policy was in effect and resulted in a settlement grant encompassing the survey area which was given to John McMul Ten and James McGloin on August 16, 1828. The first documented settlement in the reservoir was not until 1858, with the Yarbrough Bend community, located on the Frio River roughly between the Live Oak-McMullen County line and present day Tilden, Texas. This settlement was not formaliy organized, but grew Targely in relationship to Oakville (near Three Rivers, Live Oak County) and Rio Frio (also known as Dog Town, now Tilden). Yarbrough Bend never had many people (for example, three or four families in 1876). Early settlers apparently engaged in limited agriculture, hunting game, and catching and domesticating feral cattle and horses. Following various surges and losses in the cattle, horse, and sheep operations, the more recent pattern of fenced cattle ranching began after the 1880s. Yarbrough Bend settlers, many of whom held untitled land, moved away, and the area, considerably changed by overgrazing and erosion, was abandoned. Petroleum resources became important in the area soon after 1900, especially near the town of Calliham. At the present time, the cattle industry continues, and recently mining of low-grade uranium has been initiated. 
Related Archaeological Studies

Members of the Coastal Bend Archeological Society (CBAS) and Walter Wakefield of the Texas Archeological Salvage Project performed the first significant site-recording activities in the Choke Canyon area. The CBAS recorded over 50 sites, al though some site records were modified by later investigations. Wakefield (1968) located 18 sites. The initial major survey was performed by crews from the Texas Historical Commission (THC) with field work conducted in 1974 and again in 1976 (Lynn, Fox, and O'Ma17ey 1977). This THC survey involved approximately 20,000 acres (8094 hectares); 161 prehistoric and 11 historic sites were recorded. A second major survey was conducted in 1977 by Texas Tech University's Cultural Resources Institute (CRI), under subcontract to the Center for Archaeological Research, The University of Texas at San Antonio (Thoms; Montgomery, and Portnoy 1981). The CRI work resulted in the recording of 113 sites, including nine sites with historic evidence. The cumulative total of known sites in the Choke Canyon Reservoir was ca. 300 prior to CAR's 1979 survey.

Other work carried out near the study area includes that of creel et al. (1979), Shafer and Baxter (1975), and Black (1978). Recent work by the Texas Department of Highways and Public Transportation at 41 LK 28 in the Oakville area will provide important new information. Ethnohistoric research for the Choke Canyon area has been done by Campbe11 and Campbe11 (1981).

\section{METHODOLOGY}

The planning of field work of this survey pertained to the benefits that could result for southern Texas archaeology and the Choke Canyon Reservoir, as set forth in Bureau of Reclamation requirements (Solicitation No. 5B-V0527) and the CAR proposa1. Obvious requirements were: (1) to examine specified areas thoroughly; (2) to record as much useful evidence as possible, in a fashion compatible with earlier surveys; and (3) to initiate further evaluation of new data addressing basic questions concerning the cultural resources (i.e., specific site recommendations).

The Texas Tech University (CRI) work by Thoms and Montgomery provided the site definition format and field techniques on which the CAR survey was largely based. The concept of intensive surface survey was followed. It is rarely possible to totally examine any area and, therefore, a reasonable effort to approach the problem is by use of the transect method. A crew of surveyors walks zigzag patterns along parallel bearings. Alignment with available fences, vegetation lines, roads, etc., and spacing between crew members usually no more than 75 meters, must be maintained. A series of adjoining sweeps is often needed to cover an area; extremely smal1 and odd-shaped areas may be randomly walked. Effectiveness can depend on terrain, visibility, walking speed, and crew organization, with good maps and crew communication also being important.

Several reasons existed for choosing the CRI survey guidelines over those of the THC survey; these included budget, area to be covered, and definition of techniques. Much of this is evident in Appendix I. The CAR project had funding comparable to that of both previous studies, but relative to area, only the 
CRI work was nearly equa 1: the Texas Historical Commission had over 50 percent more land to examine. CRI and THC also included some minimal site testing. Although both earlier studies were based on the intensive survey concept, the THC report did not have a greatly detailed methodology section. THC intensive coverage was probably less thorough due to the much larger area. The Texas Tech University CRI survey better matched the area to be examined by CAR. Detailed descriptions of strategy and field techniques were provided. A written site definition was very helpful and diminished confusion over what field evidence demanded in terms of recording. The CRI approach did take more time for a given area than an informal survey would, and the problem of site identification was not totally resolved.

The Texas Tech definition of a site as used for the Choke Canyon area is: any $25 \mathrm{~m}^{2}$ area exhibiting "10 or more cultural items, including tools, lithic debitage . . " (Thoms, Montgomery, and Portnoy 1981). Knowing the genera 1 nature of evidence in the reservoir to be widely scattered, but not always of site density, the identification of low density scatters and isolated finds was recorded. Based on information from Collins (1975) and Schiffer, Sullivan, and Klinger (1978), Texas Tech recorded low density artifact scatters "as an obvious near-site-level concentration of cultural materials." These were mapped and described in field notes. An isolated artifact was seen as "a single potentially diagnostic cultural item... . Site limits were not always shown only where a site material density was located, but took also into consideration some cohesion of topographical setting and obviously related evidence.

For the CAR survey, historic sites were not recorded unless an age of about 50 years or more seemed apparent. This was considered compatible with earlier work.

Field equipment was kept to a minimum. Each person carried or had available in the vehicle the following: a day pack, compass, pedometer, writing material (clipboard, paper, pen/pencil), canteen, insect repellant, hat, long-sleeve shirt, plastic snake leggings, rubber boots, aluminum walking pole, flagging tape, and rain poncho. Additional equipment distributed among crew members included: site recording forms, USGS and Bureau maps, a rule, a 35-mm camera with wide angle and a $35-\mathrm{mm}$ lens and Plus $X$ black and white film, about six permanent aluminum datum stakes and scriber, a light hammer, snakebite kit, paper bags and marker, and a hand tape measure.

The first step of field implementation was determined by clearance and location for Bureau specified plots, usually consisting of one or a group of properties. First viewing would be by map and vehicle, for an assessment of the kind of terrain and sites that might be expected, and the best method to cover the area. Fencelines, utility lines, vegetation boundaries, drainages, upland slopes (often near 233-foot contour), and roads most often guided transects. Smaller divisions of fenced or sendero-blazed land allowed wel1controlled walking. A given area might have transect directions in any combination following these guides, but intensive coverage remained equal. The crew members with the aid of compass bearings, relied on three main factors for survey stability: a starting point, at least one 7 ine to follow (or "dress to") for the transect, and a stopping point. An example of a 
starting point would be lining up along a fenceline from a right-angle connection to another fenceline, to which one traveled parallel. The 233-foot contour floodline served as a boundary for most transects, although a few sites were recorded at and above it. Initial spacing was approximately $50 \mathrm{~m}$ between surveyors but did vary at times from less than $50 \mathrm{~m}$ to ca. $75 \mathrm{~m}$. The person on the outside (unguided) end of the transect "sweep" placed fiagging tape for guides on the return walk, and usually followed his own flags on the return sweep. Crew members interchanged guiding positions throughout the survey. For efficiency, transects attempted to provide a return trip to the vehicle, and if necessary the vehicle was moved. This provided extra visual alignment and also kept a vehicle nearby for extra supplies or emergencies. Transect lines were followed in an informal zigzag pattern that varied considerably (see following discussion of procedural changes). The slowest walker usually regulated the group. Vocal contact was continuous.

The field recording improved in coordination as the survey progressed, with no essential changes. Observed cultural evidence was immediately called out, at which time the crew followed one of the three procedures: stopping to discuss and record the evidence; slowing down while evaluating it; or completing the transect before discussing it and possibly returning to record it. Isolated finds and low density scatters were recorded on the Bureau work maps

(1:800-inch) and briefly listed in a log book Roemer kept of dates, sequence numbers, and comments. Isolated finds were usual7y reported during a transect without stopping. Low density scatters often spread across the width of a sweep and were discussed on location or after the transect (naturaliy some of these "became" sites, and vice versa). When a site was detected, the group usually walked out its area and retrieved artifacts for sketching, leaving flags for replacement of the specimens. Discussion followed as Lukowski filled out site computer forms, and Roemer completed UTSA written forms. (Examples of the site computer and written forms are provided in Appendix II.) Stiba photographed the site and artifacts and also sketched artifacts, while white continued site inspection, inscribed and placed the datum, and plotted or checked maps.

Using the estimate of 8400 acres (3400 hectares) covered in 159 person/days, a survey rate averaging 53 acres (21 hectares) per person/day is the result. This is close to the CRI rate estimates of 49 acres (20 hectares). per person/day. On typical survey days the crew members would each walk 8-12 miles. Fortyfive minutes was the average time required for recording one site, but there was considerable variation. Keeping the three or four person crew together to record a site was found to be most productive, since it was difficult for transects to remain aligned if several people went on ahead.

Collection policy stipulated that collection be restricted to endangered artifacts, resulting in a minimal number of specimens (see ARTIFACTS section). Usually those artifacts which were collected were either located where erosion or poor visibility made it highly unlikely that they might ever be found again, or were located where they were likely to be picked up by relic collectors (whose numbers are expected to increase when the rigidly patrolled private property becomes public). In most other situations, artifacts were left in place for later, more precise recording. Stone tools in collapsing gully wall situations were sometimes collected; potsherds which are difficult to locate, 
much less relocate, due to their color and small size, were also collected. Al1 collected artifacts were plotted in relation to the site datum, which was noted on the artifact bag and/or the field site form. Isolated finds were also plotted and documented in a similar fashion.

A11 crew members took general notes, which often required several hours of work in the evening. Roemer also showed daily transects by tracing from USGS maps. Some changes from the original specifications evolved. Surveyor intervals with $100 \mathrm{~m}$ spacing and highly controlled "zigzagging" were desired. Defining (i.e., controlling) this manner of coverage is perplexing. Certain compass bearings for a mutual time and distance would be required, implying synchronization of the "zigs" with the "zags"; otherwise group drift and individual spacing suffer. The vegetation at Choke Canyon adds to the difficulty. The CRI report does not elaborate beyond stating that 2.5 to 3 times the straight transect's distance was covered, utilizing a $65 \mathrm{~m}$ zigzag spacing which would equal a $32.5 \mathrm{~m}$ straight transect spacing. The CAR experience probably approached this coverage, but precise measurements cannot be given. partially because pedometers tended to overcount (see below). It was resolved to walk straighter and closer transects. Spacing tightened to the $40-70 \mathrm{~m}$ range, and good coverage resulted. From another perspective, brush cover necessitated angular transects.

Site boundaries were not flagged. For relocation, the aluminum datum stake, sometimes with a flag near it, was considered sufficient. Excessive flagging hinders site protection and, although the flags are biodegradable, is unpopular with local ranchers.

Vocal contact was effective and insured close spacing. Pedometers aided surveying, but they are knocked off easily when worn in the brush and tend to overcount when a crew member maneuvers through thick brush. They can provide rough measurements for site diameters and total transect distances.

Other problems encountered are familiar to archaeologists working in southern Texas. Vegetation greatly hindered visibility and mobility. This varied, but usually was a significant factor, because the survey occurred in late spring and summer after a period of above normal rainfall. Eroded areas often displayed evidence best, but in a fashion that provided the most disturbance. Defining cultural material was much better with the predetermined standards. However, it can be said that some low density scatters are probably sites, and some recorded sites resemble low density scatters to a remarkable degree. Part of the explanation here is intensity of inspection and physical surface exposure. The former is controllable and was reasonably consistent.

CAR computer site forms were also filled out for all sites. The data have been stored, but are not manipulated in this report. 
STUDY AREAS

For purposes of examination, the Choke Canyon Reservoir area has been divided into eight general areas of survey activity, which are partially related to the order in which they were investigated in the field. The numerical designations are arranged from east to west across the Frio basin.

In this section, details are provided on where the site survey took place, what the environment was like (and will be), and the general nature of cultural evidence. Area estimates are considered conservative and were obtained by grid estimation techniques.

Area 1

Located on the western edge of Live Oak County, Area 1 is south of the Frio River along the valley wall, running about $6.4 \mathrm{~km}$ in length (Figs. 2; 10,a). Area 1 follows the northern side of rerouted State Highway 72 (which begins $3.2 \mathrm{~km}$ west of Three Rivers). The limit downslope (north) from the highway is the 233-foot contour, a width usually about $500 \mathrm{~m}$ or less. The total acreage of this strip is ca. 777 acres ( 314 hectares).

Topographically, Area 1 displays a valley wall situation. The Frio River is 2.08-2.72 km away, with most of this area consisting of minor drainages, sloughs, and gently rolling floodplain. The lower valley wall slope begins at about the 200-foot elevation, reaching the upland ridge tops (separating the Nueces River drainage from the Frio River basin) at elevations approaching 280 feet. A typical gradient is 80 feet $(24.4 \mathrm{~m})$ - in a distance of 3000 feet $(914.4 \mathrm{~m})$. The Catahoula geologic formation provides a combination of tuffaceous outcrops, clay, and thin silty soils. Overlying Uvalde gravels are abundant, often exposed in sheet washes or gullies.

Vegetation consists of moderate to thick brush with grasses intermixed. Typical plants include mesquite, acacia, soapbush, sage, prickly pear, agarita, mountain laurel, yucca, spiny hackberry, and whitebrush. Where minor drainages originate on the slopes and topsoil is thick, the densest vegetation usually exists. Barer ground with moderate brush is found on the upland areas. Severe erosion has created a few locations with extensive gullies and sparse vegetation.

This valley wall area shows extensive prehistoric utilization. Previous survey activity recorded 18 sites from the lower valley wall (ca. 200-foot elevation) up to the highway. These are CRI sites from surveys mainly below the $230-$ foot elevation (41 LK 173, 41 LK 174, 41 LK 176, 41 LK 177, 41 LK 178, 41 LK 179, 41 LK 180, 41 LK 181, 41 LK 187, 41 LK 190, 41 LK 197, 41 LK 192, 41 LK 193, $41 \mathrm{LK} \mathrm{194)}$ and sites located within highway construction by the Bureau (41 LK 203, 41 LK 204, 41 LK 205, and 41 LK 206). Five sites were recorded by the UTSA crew: 41 MC 228, 41 LK 239, 41 LK 240, 41 LK 241, 41 LK 242. General site characteristics in Area 1 suggest a combination of 7 ithic procurement, tool making and utilization, and some fire-building activities. Site depths usually appear shallow. A light scatter of lithic tool procurement and reduction evidence exists almost wherever the natural gravel is seen, and concentrated evidence is not readily obvious. 
Figure 2. Sites Recorded in Study Areas 1 and 2

PAGE 24 REDACTED 
A narrow strip of land will separate the reservoir's edge and State Highway 72 . Extensive relic collecting and disturbances such as wave erosion and fluctuating water levels will occur.

\section{Area 2}

The largest contiguous area surveyed, Area 2 (Figs. 2; 9,a,b) formed a long rectangle south from the Frio River to the western-most valley portion of Area 1, roughly $2.08 \mathrm{~km}$ east-west and $3.68 \mathrm{~km}$ north-south and split by old Highway 72. It is primarily on the western edge. of Live Oak County; total acreage is ca. 1881 acres (761 hectares).

Topographically, Area 2 includes the major floodplain and lower valley wall. Two small drainage systems flow in a northeasterly direction across it. Elevations run from less than 150 feet $(45.7 \mathrm{~m})$ on the river channel to ca. 230 feet $(70.1 \mathrm{~m})$ near the valley wall at rerouted Highway 72 . The Frio formation and more recent alluvial deposits of silty soil with sparse gravels compose most of Area 2. Pleistocene terrace remnants near the Frio River exhibit more gravels and clay.

Half of Area 2 is in cultivation or coastal Bermuda grass. The lower valley wall retains some thick brush, such as mesquite, soapbush, spiny hackberry, acacia, prickly pear, whitebrush, yucca, sage, and native grasses. Another area of ca. 400 acres (162 hectares) located south of old Highway 72 has thick growth such as whitebrush, mesquite (some are large), prickly pear and other cacti; soapbush, persimmon, retama, and grasses.

A relatively low number of sites (eight) was discovered in Area 2 during this survey. Previously recorded sites were near the river channel and from the CRI survey eastward. Two sites were located near the Frio River, 41 LK 235 and 41 LK 236, and others were along the upper reaches of the minor drainages, 41 LK 231, 41 LK 232, 41 LK 233, 41 LK 234, 41 LK 237, and 41 LK 238. These sites exhibited burned chert, flakes, finished lithic tools, mussel, some ground sandstone, and a trace of pottery. Lithic sources were not observed at the sites, but outcrops on the Pleistocene terraces and valley wall are nearby. Two historic sites also exist not far below the valley wall where a county road meets rerouted Highway 72 . These are 41 MC 229 and 41 MC 230 and appear to be post-1900 farming homesteads.

Area 2 will be mechanically cleared and inundated.

\section{Area 3}

This study area (Figs. 3; 10,b) was a discontinuous valley wall on the northern side of the Frio River, extending from the McMullen-Live Oak County border to about $5.76 \mathrm{~km}$ east. Opossum Hollow is also nearby to the south. Several areas were in upper drainage bottoms contained by the 233-foot floodline, and others were valley wall-upland protrusions above the 233-foot contour. The survey covered 1150 acres (465 hectares). 01d State Highway 99 exists nearby to the west.

Topographically, Area 3 consists of valley walls including transition to uplands and certain upper floodplains of feeder drainages to Opossum Hol low and 
Figure 3. Sites Recorded in Study Area 3.

PAGE 26 REDACTED 
Willow Hollow Creeks. Elevations range from 180 feet to 255 feet. The valley wa11 gradient was comparable to that of Area 1. The upper Whitsett unit of the Fayette formation is composed of clays and sandy clays, overlain by the Frio formation, extensive Uvalde gravels, and alluvial deposits. Petrified wood, including palmwood, is common.

Vegetation on the valley walls and upland transition consists of moderate to very heavy brush with sparse grasses. Acacia, mesquite, mimosa, guajil1o, soapbush, sage and cactus were observed. In the upland drainage bottoms whitebrush was found in addition to the other brush. Lower drainage areas nearer Opossum Hollow displayed some persimmon among continued brush. Only minor portions of Area 3 seem to have been recently cleared.

Eleven prehistoric sites were recorded in Area 3. Evidence consisted mainly of burned chert, 1ithic debitage, and finished tools. Hearths, pottery, mussel and land snails reflect occupation areas. These are near the opossum Hollow drainage system. Like the valley wall gravel of Area 1, 1ithic procurement and reduction evidence is extensive, but in low density. Sites newly recorded by UTSA are 41 LK 243, 41 LK 244, 41 LK 245, 41 LK 246, 41 LK 247, 41 LK 248, 41 LK 249, 41 LK 250, 41 LK 251, 41 LK 252, and 41 LK 253.

Brush clearing will take place in the drainage areas up to ca. 220-foot elevation, with predicted inundation to 233 feet. Wave erosion and fluctuating water levels affect about half of Area 3 and may erode sites. An extensive recreation area will be developed in the eastern upland areas. This will involve some clearing for development and will probably lead to extensive mineral and relic collecting.

\section{Area 4}

This is a portion of the Salt Creek drainage in McMullen County, located southwest of Calliham and south of old Highway 72 (Figs. 4; 8,a). Three major branches running about $3 \mathrm{~km}$ south-southwest to north-northeast were surveyed, located between two north-south county roads $2.3 \mathrm{~km}$ apart. Inspection was delimited by the highway in the north, the county road in the east, and below the 233-foot flood contour elsewhere. Total area was ca. 770 acres (312 hectares).

Area 4 is a good example of bottomlands associated with a small tributary. The Frio River confluence is $3 \mathrm{~km}$ north-northeast of the central study area. Valley walls exist just south of the 233-foot contour limits, with ridge-top elevations over 250 feet. A typical slope from the 250-foot elevation down to the Salt Creek bottom at 200 feet is a 15.2 meter (500-foot) drop in 488 meters distance. Area 4 is in a transition zone between the Fayette formation's Whitsett beds (west) and the Frio formation (east). Clay characterizes the soils, with light scatters of smal1 gravel, including petrified wood. Large amounts of gypsum are seen in eroded areas. Standing water was observed (May 1979) in smal1 sloughlike portions of Salt Creek.

Six prehistoric sites and one historic site were recorded in Area 4: 41 MC 231, 41 MC 232, 41 MC 233, 41 MC 234, 41 MC 235, 41 MC 236, and 41 MC 237. The prehistoric evidence consisted of lithic debris and tool scatters, burned 
Figure 4. Sites Recorded in Study Area 4.

PAGE 28 REDACTED 
chert, small amounts of sandstone probably representing hearth activity, and traces of mussel and land snail. The use of petrified wood was noted among the lithic artifacts. Sites in Area 4 suggest activity apart from the procurement phase of lithic tool-making. However, major lithic resources are not far away (i.e., gravels to the south, sandstone northwest). Site depth generally does not appear substantial. The historic site (41 MC 237) is located just north of Highway 72 and appears to be a forge or kiln represented by a brick foundation. All of Area 4 will be cleared and inundated, with extensive recreation and road use nearby. Some sites will be subjected to wave erosion and fluctuating water levels.

\section{Area 5}

Area 5 (in McMullen County) is a rectangular area located along the western side of the Frio River where it flows south-southwest from Yarbrough Bend (Figs. $5 ; 8, \mathrm{a}$ ). At the eastern river border, it is $\mathrm{ca} .1 .2 \mathrm{~km}$ west to the 233-foot contour. Northern and southern limits are determined by east-west property lines, about $2.2 \mathrm{~km}$ apart. A north-south county road bisects Area 5. Total acreage is 734 acres (297 hectares).

Area 5 is made up largely of Frio River floodplain. A small primary drainage network flows from west to east and connects through a system of sloughmeanders running parallel to the river. Elevation runs from 180 feet on the river channel to the 233-foot flood contour. The Frio River is particularly wide and deep in this region, partially due to the confluence of San Miguel Creek upstream. Clays and sandy clays of the Fayette formation's Whitsett unit occupy Area 5, combined with recent alluvium. Little gravel exists until the valley wall areas over the 233-foot elevation are reached.

Most of Area 5 is in various degrees of brush or riparian vegetation, with about one-third in cleared pasture. Brush includes mesquite, retama, cactus, soapbush, whitebrush, guaji110, and spiny hackberry. Hardwoods such as oak and $\mathrm{e} 1 \mathrm{~m}$, along with mustang grapevines and thick grasses, are dominant on the lower floodplain. Some very thick whitebrush is located in the western drainage bottoms.

The nearest previously surveyed sites are 41 MC 53 to the north, and 41 MC 66 and $41 \mathrm{MC} 69$, to the south. The new sites are 41 MC 238, 41 MC 239, 41 MC 240, 41 MC 241, 41 MC 242, 41 MC 243, 41 MC 244, and 41 MC 245. Prehistoric sites in Area 5 distinctively run along the modern floodplain's terrace bank, which is roughly $250 \mathrm{~m}$ west and parallel to the Frio River channel. This follows the 200-foot contour closely, with sloughs often immediately below. Evidence is shown by scattered mussel fragments, finished stone tools and lithic debris, some ground sandstone, burned sandstone, and land snails. The one site differing from the others was 41 MC 239, a prehistoric site set on the val1ey wall gravel outcrops in the west, actually above the 233-foot limit. In addition to chert, much palmwood occurred near this site, both in natural form and as lithic debitage. The valley wall of Area 5 was possibly the lithic procurement area for the river terrace sites, which appear related to riverine exploitation. Perhaps because of poor visibility, the portions of Area 5 other than the 200-foot terrace had very 1ittle evidence of prehistoric occupation, including low density scatters. 
Figure 5. Sites Recorded in Study Area 5 and Playa Area.

PAGE 30 REDACTED 
Site 41 MC 240 is a historic site, a capped 011 well casing in a gully area. It is important primarily because it is the location of one of the very first $0 i 1$ wells in the area, as noted by the state historic marker in Calliham. Site 41 MC 245 also has a historic designation by the presence of a standing wood frame structure.

All of Area 5 will be inundated. Brush clearing will be restricted to the channel area, but may affect 41 MC 238 and 41 MC 241, 41 MC 242, 41 MC 243, 41 MC 244, and 41 MC 245. State Highway 99 will also be rerouted along the western upland side of Area 5. Wave erosion and fluctuating water levels will take place here.

\section{Area 6}

Area 6 is located in McMullen County in the upper drainages of Elm Creek (Figs. $6 ; 14, a)$. This is at a point of $3.52 \mathrm{~km}$ north of the Frio River-San Miguel Creek confluence. Access is either from the Teal crossing on San Miguel Creek (southwest) or through the Jambers Ranch (northeast). This small area was determined by an east-west property line in the south, with the 233-foot contour forming other boundaries in a series of southward-flowing drainages. Total acreage was 143 acres (58 hectares).

Within Area 6 is an upper drainage floodplain of a small Frio River tributary, probably comparable in volume to Salt Creek. Elevations are from 218 feet to 233 feet. A valley wall protrusion over 270 feet splits two of the major drainage courses. About $3.2 \mathrm{~km}$ southeast of the study area, E1m Creek joins the Frio River at the northern loop of Yarbrough Bend. The Lipan (Tower) unit of the Fayette formation occurs here with clay, sandstone, and some gravels, plus recent alluvium.

In terms of vegetation, Area 6 consists of a coastal Bermuda grass floodplain with varying amounts of larger vegetation in the drainage bottoms and on the valley slopes. Mesquite, whitebrush, persimmon, elm, oak, and native grasses exist along the creek bottoms. Higher elevations display mesquite, prickly pear, soapbush, acacia, and yucca. Several large stock tanks are in or near Area 6, such as 01d Rock Tank, now largely silted in. Some retama and eroded open areas of clay soil are scattered in the pasture area.

Five prehistoric sites were recorded in Area 6, 41 MC 276, 41 MC 277, $41 \mathrm{MC} 278,41 \mathrm{MC} 279$, and $41 \mathrm{MC} 280$. About $500 \mathrm{~m}$ east, $41 \mathrm{MC} 73$ is the nearest previously known site. Lithic debitage and tools, burned chert and sandstone, mussels and land snails were observed. Late Prehistoric traits, bone preservation, and ground sandstone were noted at certain sites. This amount of evidence was, to the survey crew, unexpected, given the study area's greater distance from the Frio River.

Area 6 will be inundated. Fluctuating water levels and wave erosion will occur. 
Figure 6. Sites Recorded in Study Areas 6, 7, and Jambers' Property

PAGE 32 REDACTED 
Area 7

Area 7 is in McMullen County near the San Miguel Creek confluence with the Frio River, including both sides of the Frio River, the eastern bluffs of the Yarbrough Bend loop and small portions north of San Miguel Creek several miles back from the river (Figs. $6 ; 12 ; 14$ ). The basic area has a width of about $1 \mathrm{~km}$ centered on the Frio River running west for several miles back from the mouth of San Miguel Creek. State Highway 99 is being rerouted just east of Area 7. Total surveyed acreage is 1401 acres (567 hectares).

The terrain includes the Frio River floodplain, the lower southern San Miguel Creek floodplain and the steep valley wall along the right bank of the Frio River (opposite San Miguel Creek). Elevations are below 190 feet on the river channel to the valley wall limits of 233 feet. Eastward, the ridge of Yarbrough Bend has heights of 290-foot elevation, with Area 5 beyond this. The Lipan unit of the Fayette formation created these resistant sandstone bluffs which have determined the looping course for the Frio River. The sandstone is in both unconsolidated form and resistant slabs. The majority of Area 7 has silty-loam alluvium from the Frio River over the Fayette clays. Gravel deposits noted during the survey.existed in the San Miguel Creek channel and on valley walls north of that stream. Several slough or ancient channel meanders exist near the San Miguel Creek and the Frio River. Several other minor drainages join the Frio River from the south.

Most of the floodplain of Area 7 has been cleared for cultivation. Heavy vegetation remains along the stream bottoms include oak, elm, hackberry, mustang grapevine, and thick grasses. Vegetation on the terrace fringes includes whitebrush, mesquite, persimmon, and soapbush. Valley wall areas have mesquite, blackbush, prickly pear, yucca, soapbush, acacia, agarita, whitebrush, Mormon's tea, and grasses.

Twenty-eight sites were recorded in this area, 10 of which had at least some historic materials. All of the sites were located near the San Miguel Creek or the Frio River. Common evidence was chert debitage and chipped tools, mussel, land snail, and burned chert (or often sandstone south of the river). other artifacts included pottery, ground sandstone, and worked mussel. Late Prehistoric traits were recorded at nearly half of the prehistoric sites. Most historic evidence was on the southern side of the Frio River and probably reflects part of the original Yarbrough Bend community of the 1850s and later. Typical historic material included razed sandstone structures, pottery, glass, and metal fragments. Along the steep bluffs over the river, many promontories had both historic and prehistoric artifacts. The Yarbrough Cemetery (Lynn, Fox, and 0'Malley 1977:181-183) was also revisited and recorded as a component of $41 \mathrm{MC} 18$.

The river bottom will be cleared from the east to a point just before the confluence of San Miguel Creek. A1l of Area 7 will be inundated. Wave erosion and fluctuating water levels will erode sites located nearer the valley wal1, while floodplain areas may receive heavy silt deposits. Major access areas on San Miguel Creek and the Yarbrough Bend will promote relic collecting, especially at the sites of 41 MC 272, 41 MC 281, 41 MC 282, 41 MC 283, and 41 MC 284. 
Figure 7. Sites Recorded in Study Area 8.

PAGE 34 REDACTED 
Area 8

Area 8 is located in McMullen County along the Frio River, extending from Ti7den $4.5 \mathrm{~km}$ to the east (Figs. $7 ; 11, a, b$ ). State Highway 72 runs eastwest on the south side of the Frio River and a county road exists in the north. A separate area on the Salt Branch west of the Frio River is also included, ca. $7.3 \mathrm{~km}$ east-northeast of Tilden and west of the adjacent county road. Survey limits were predominately set by the 233-foot elevation. Total area is 687 acres (278 hectares).

In the upper portion of the reservoir, the Frio River channel is tightly contained by the 233-foot contours. Lower portions of the valley wall are nearby on the southern side of the river. In the eastern portion of Area 8, the river channel cuts below the 218-foot elevation. The river also forms several major meanders which reconnect through slough systems. These sloughmeanders are supplemented by Cottonwood, Hackberry, Sloppy Hollow, and Salt Branch Creeks (a different Salt Branch from the one previously mentioned). The Fayette formation produces prominent sandstone hills near here, such as Skillet Mountain (372-foot elevation). Some gravel deposits are present on the southern side of the Frio River where the valley wall is steep. Most soil in Area 8 is recent al7uvium, often deep.

Vegetation in Area 8 involves various amounts of brush and grass and cultivation on slough-contained floodplain "islands." The river bottom typically shows hardwoods such as oak and elm, briar, mustang grape and poison ivy vines, and tree mosses. Brush fringes the river bottom and the tributaries: acacia, soapbush, yucca, prickly pear, mesquite, and whitebrush.

A total of 16 sites were recorded in Area 8: 41 MC 246, 41 MC 247, 41 MC 248, 41 MC 249, 41 MC 250, 41 MC 251, 41 MC 252, 41 MC 253, 41 MC 254, 41 MC 255, 41 MC 256, 41 MC 257, 41 MC 258, 41 MC 259, 41 MC 260, and 41 MC 261, including one historic site, 41 MC 256. One prehistoric site (41 MC 261) was located in the separate Salt Branch area (eastward). The prehistoric sites all reflect the presence of water, i.e., five near the Frio River, seven on slough-meanders, and three along tributaries. Common traits are chert debitage and tools, burned chert and sandstone, mussel and land snail. Pottery, ground stone and bone also occurred at 41 MC 260. Except for 41 MC 253 and 41 MC 254, prehistoric sites appeared as occupation sites away from lithic procurement locations. Possibly some areas in the Frio River channel contain siliceous gravels not observed by the survey. The historic site 41 MC 256 is a dump area located on prehistoric 41 MC 255.

Brush clearing will not occur in Area 8. Partial, occasional flooding will occur up to the 233-foot contour. Slough-meander channel may reach maximum capacity. Fluctuating water levels and alluvial deposits will affect sites. 
ADDITIONAL STUDY AREAS

Playa area

This was a small area located around a natural playa that is $1.8 \mathrm{~km}$ east of the Frio River's Yarbrough Bend (Fig. 5). Access is by driving in across Opossum Creek from old State Highway 99. The survey area was higher than the 233-foot elevation contour and limited on the high side by a fence. The area totaled 173 acres (70 hectares).

This relatively flat area is located between the Opossum and Frio floodplains, and several natural playas are seen here. Soil is sandy with slight amounts of gravel. The geologic formation below the alluvium is the Fayette (Jackson group).

Vegetation is moderate to thick mesquite, soapbush, whitebrush, and sparse grasses. A distinctive weed grows in the playa bottom, possibly the Drummond rattlebox.

No cultural' evidence was seen in this area. Because of the potential water resource, the playa situation might be expected to reflect prehistoric activity, but no hint of this was observed from surface examination. The edge of 41 MC 179 was also investigated, with no material noted.

This area is just above the flood line.

Jambers property

North of the Frio River, this was a large block of land west and south of Elm Creek (Fig. 6). It lies between Study Area 6 and eastern Study Area 7, mainly on the Jambers brothers' property the total area surveyed was 679 acres (275 hectares).

This area consists of the Frio River and Elm Creek floodplains. Except for the drainage banks, it is markedly flat, with alluvium-clay soils and little grave1. The Fayette formation prevails here beneath recent alluvium.

Vegetation such as mesquite, whitebrush, cactus, persimmon, acacia, and ta11 grass exists in a relatively thick, consistent cover. Some areas have secondary growth over previously cleared fields. Elm trees, leafy weeds, and thick grasses run along the course of Elm Creek.

Three prehistoric sites and several low density scatters were recorded, a11 near Elm Creek (41 MC 296, 41 MC 297, and 41 MC 298). Site evidence involves 7 ithic debitage and tools, burned chert, some sandstone, pottery, bone, mussel and land snail. Several sites have substantial depth. Site 41 MC 63 was revisited. Although a vast area of floodplain was surveyed on the Jambers property, no sites were found by earlier workers from the Texas Historical Commission (Lynn, Fox, and O'MaTley 1977).

A11 of this area will be inundated. 


\section{ARTIFACTS}

This section will provide a generalized description of the material evidence encountered by the CAR survey. As previously mentioned, a policy of minimal collection was observed. It may be, however, that more intensive "grab" sampling would have been beneficial in view of the extensive relic collecting in the Choke Canyon area, especially on lands now more traveled and more easily trespassed than when in private ownership. The artifacts that were collected by CAR had potential interpretative value and were not only those endangered by relic collectors, but also those that appeared likely to be displaced or lost to natural causes. Greater collections were made of historic material both to avoid relic hunters and to afford additional chronólogical and functional data for specialists at the laboratory.

General Observations

The bulk of the surface material observed during the CAR survey was prehistoric in date and was quite similar to the kinds of artifacts reported in detail in the earlier THC and CRI surveys. Collecting of artifacts was restricted to those items that could provide diagnostic information (especially temporal or functional) on the site. A general indication of the materials observed at prehistoric sites is shown in Table 1. The lithic forms noted in that table are those most often observed during this survey.

In making field observations of artifacts not collected, subjective descriptions, such as "scraper," "utilized flake," and "preform" were often used. An effort was also made to record the kind of raw material used in artifact manufacture (e.g., petrified wood). In recording the presence of "thin" or "thick" bifaces, an arbitrary measurement of $.5 \mathrm{~cm}$ was used in the field. The use of the term "gouge" in the field notes refers to a series of lithic forms common in the Choke Canyon area, including such previously defined categories as Guadalupe (Hester 1980a:6, 12), and Clear Fork (cf. Epstein 1969). Distinctive forms, assumed to be scrapers, were also recorded, such as the Nueces category of Hester, White, and White (1969:148).

Ground stone artifacts were usually fragments of modified sandstone, but Targe metates and manos were also recorded. In addition, some manos were made of fine-grained quartzite or chert (41 LK 244, 41 MC 294); one specimen had abrader-1ike grooves (41 LK 247). A stone bead was found at 41 MC 260.

Archaeological features were most often represented by burned rock concentrations. Materials included chert, sandstone, and tuff stone.

observations were also made on lithic debitage at sites. Field estimates are derived from the crew's impression of density. A "low" (L) designation of debitage density often reflects what was, by definition, a minimal site.

Faunal and molluscan materials were recorded. Mussel shell fragments were common; altered specimens of mussel were seen at 41 MC 234, 41 MC 276, and 41 MC 286. At the first two sites, the mussel she11s were perforated, and at the latter, the edges of a shel1 had been ground. Land snails were also common, especially Rabdotus. Bone was rarely preserved; only at 41 MC 276 was a deer phalange identified in apparent prehistoric context. 
fABLE 1. MATERIALS OBSERVED AT PREHISTORIC SITES.*

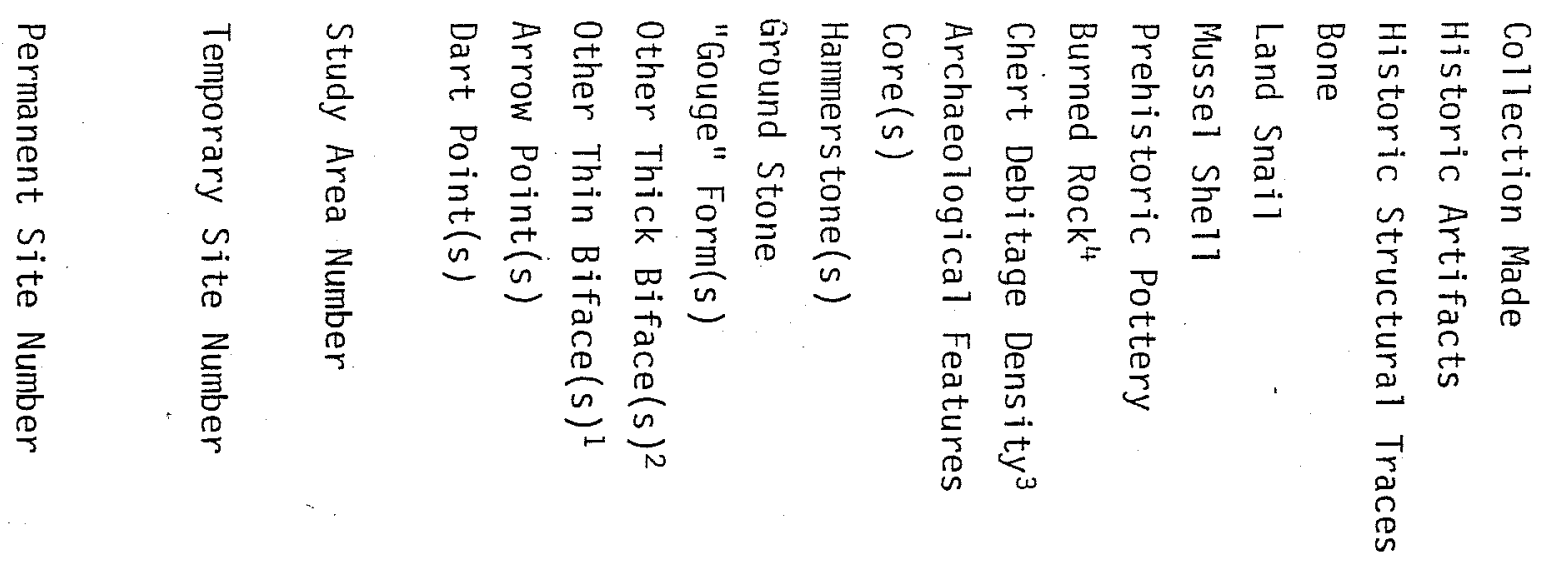

\begin{tabular}{|c|c|c|c|c|c|c|c|c|c|c|c|c|c|}
\hline 41 LK 237 & 1 & 2 & & & $x$ & & & & $L$ & $x$ & $x$ & $x$ & \\
\hline 41 LK 232 & 2 & 2 & & & $x$ & $x$ & $x$ & & $M$ & $x$ & $x$ & $x$ & \\
\hline 47 LK 233 & 3 & 2 & & $x$ & & & $x$ & & M & $x$ & & $x$ & \\
\hline 41 LK 234 & 4 & 2 & $x$ & $x$ & & $x$ & $x$ & & $H$ & $x$ & $x$ & $x$ & \\
\hline 41 LK 235 & 5 & 2 & & & & $x$ & & & $L$ & $x$ & $x$ & $x$ & \\
\hline 41 LK 236 & 6 & 2 & & & $x$ & $x$ & $x$ & $x$ & L & $x$ & $x$ & $x$ & $x$ \\
\hline 41 LK 237 & 7 & 2 & & $x$ & & & & & $L$ & $x$ & $x$ & $x$ & \\
\hline 41 LK 238 & 8 & 2 & & $x$ & & & & & $L$ & $x$ & & $x$ & \\
\hline 41 LK 239 & 11 & 1 & & & & & $x$ & & $L$ & & & & \\
\hline 41 LK 240 & 13 & 1 & & & $x$ & $x$ & & & $L$ & $x$ & & & \\
\hline 41 LK 241 & 14 & 1 & & $x$ & $x \quad x$ & & $x$ & $x$ & $M$ & $x$ & & & \\
\hline 41 LK 242 & 15 & 1 & $x$ & $x$ & & & & $x$ & M & $x$ & $x$ & $x$ & \\
\hline 41 LK 243 & 58 & 3 & & $x$ & $x \quad x$ & $x$ & & $x$ & $H$ & $x$ & $x$ & $x \quad x$ & $x$ \\
\hline 41 LK 244 & 59 & 3 & & $x$ & & $x$ & $x$ & $x$ & $L$ & $x$ & $x$ & $x$ & $x$ \\
\hline 41 LK 245 & 60 & 3 & $x$ & $x$ & $x$ & & $x$ & $x$ & $L$ & $x$ & & & $x$ \\
\hline 47 LK 246 & 61 & 3 & $x$ & $x$ & $x$ & & $x$ & $x$ & $M$ & $x$ & $x$ & $x$ & \\
\hline 41 LK 247 & 62 & 3 & $x$ & $x$ & & & $x$ & $x$ & $M$ & $x$ & $x$ & $x$ & $x$ \\
\hline 41 LK 248 & 63 & 3 & & $x$ & & $x$ & $x$ & & $L$ & $x$ & $x$ & $x$ & \\
\hline 41 LK 249 & 64 & 3 & & & $x$ & & & & $L$ & $x$ & & & \\
\hline 41 LK 250 & 65 & 3 & $x$ & $x$ & $x$ & $x$ & $x$ & $x$ & $M$ & $x$ & $x$ & $x \quad x$ & \\
\hline 41 LK 251 & 66 & 3 & $x$ & x & $x$ & & $x$ & & $L$ & & & & \\
\hline 41 LK 252 & 67 & 3 & $x$ & $x$ & $x$ & $x$ & $x$ & $x$ & L & $x$ & & & \\
\hline 41 LK 253 & 68 & 3 & & $x$ & $x$ & $x$ & & & $M$ & $x$ & & $x$ & \\
\hline
\end{tabular}

*Note: Historic Artifacts have been included. 
TABLE 1. (continued)
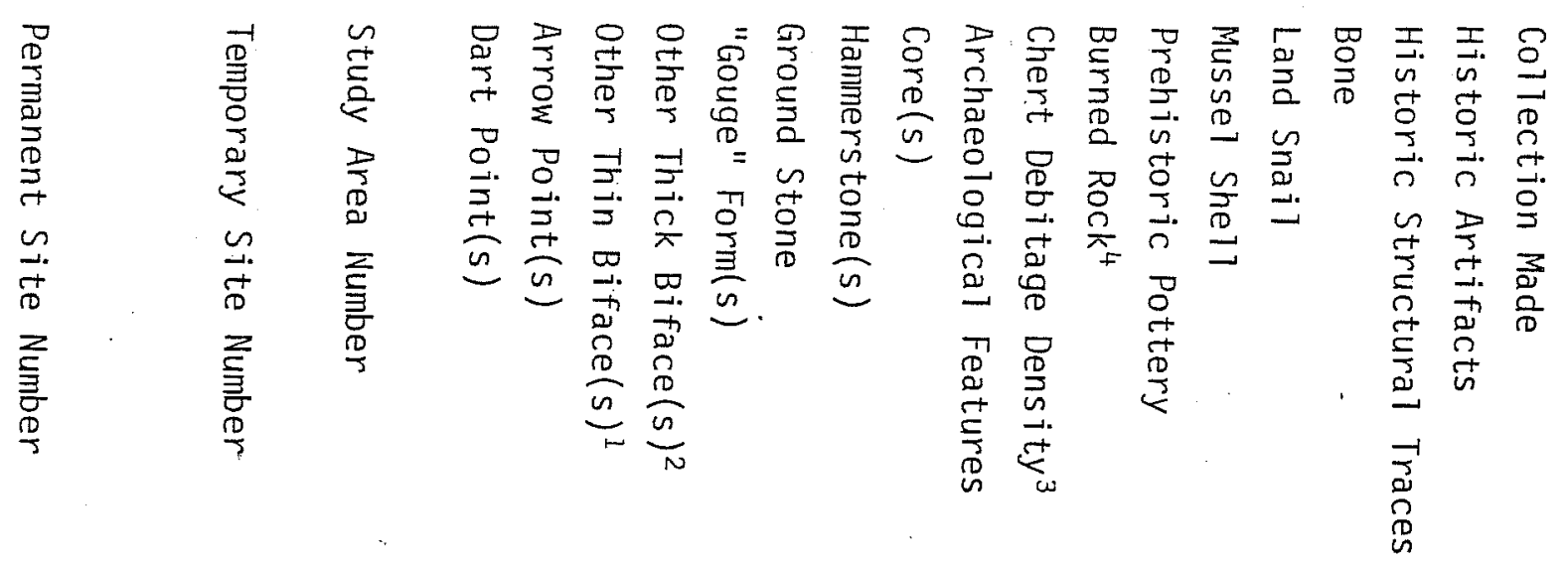

41 MC 2289

41 MC $229 \cdot 10 \quad 1$

41 MC $230 \quad 12 \quad 1$

41 MC $237 \quad 16 \quad 4$

47 MC $232 \quad 17 \quad 4$

$\begin{array}{llll}41 & \text { MC } 233 & 18 & 4\end{array}$

41 MC $234 \quad 19 \quad 4$

41 MC $235 \quad 20 \quad 4$

41 MC $236 \quad 21 \quad 4$

41 MC $237 \quad 22 \quad 4$

41 MC $238 \quad 23 \quad 5$

41 MC $239 \quad 24 \quad 5$

41 MC $240 \quad 25 \quad 5$

41 MC $241 \quad 26 \quad 5$

41 MC $242 \quad 27 \quad 5$

41 MC $243 \quad 28 \quad 5$

41 MC $244 \quad 29 \quad 5$

41 MC $245 \quad 30 \quad 5$

41 MC $246 \quad 31 \quad 8$

41 MC $247 \quad 32 \quad 8$

47 MC $248 \quad 33$

41 MC $249 \quad 34$

47 MC $250 \quad 35 \quad 8$

41 MC $251 \quad 36 \quad 8$

41 MC $252 \quad 37 \quad 8$ $x \quad x$

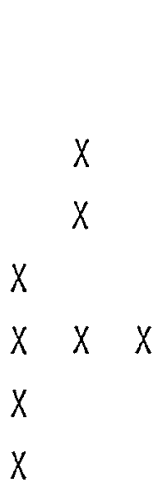

4

5

$x$

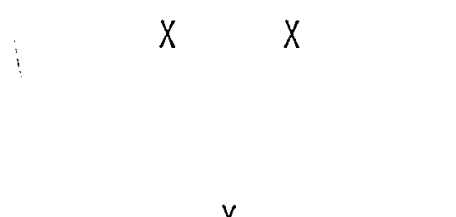

$$
x
$$

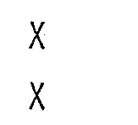

$\begin{array}{lll}x & x & x \\ x & x & \end{array}$

$x$

$X M X$

$X \quad L \quad X \quad X \quad X$

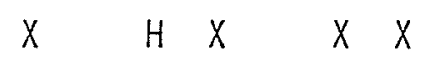

$X X L X$

$x \quad L \quad x$

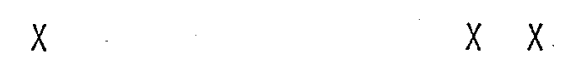

$X X H \quad X \quad X \quad X$

$X \quad L$

$x \quad x \quad x$

$X$

$x$

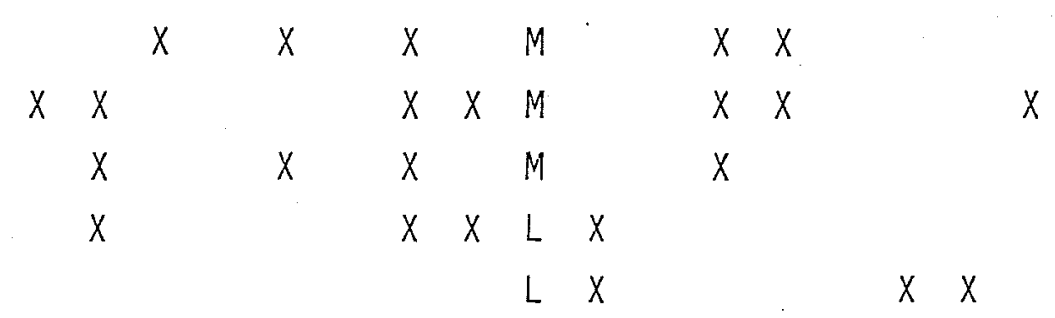

$\begin{array}{llllllllllll}x & x & x & L & x & x\end{array}$

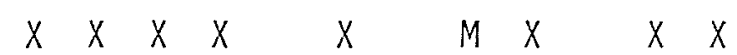

$x$ 
TABLE 1. (continued)

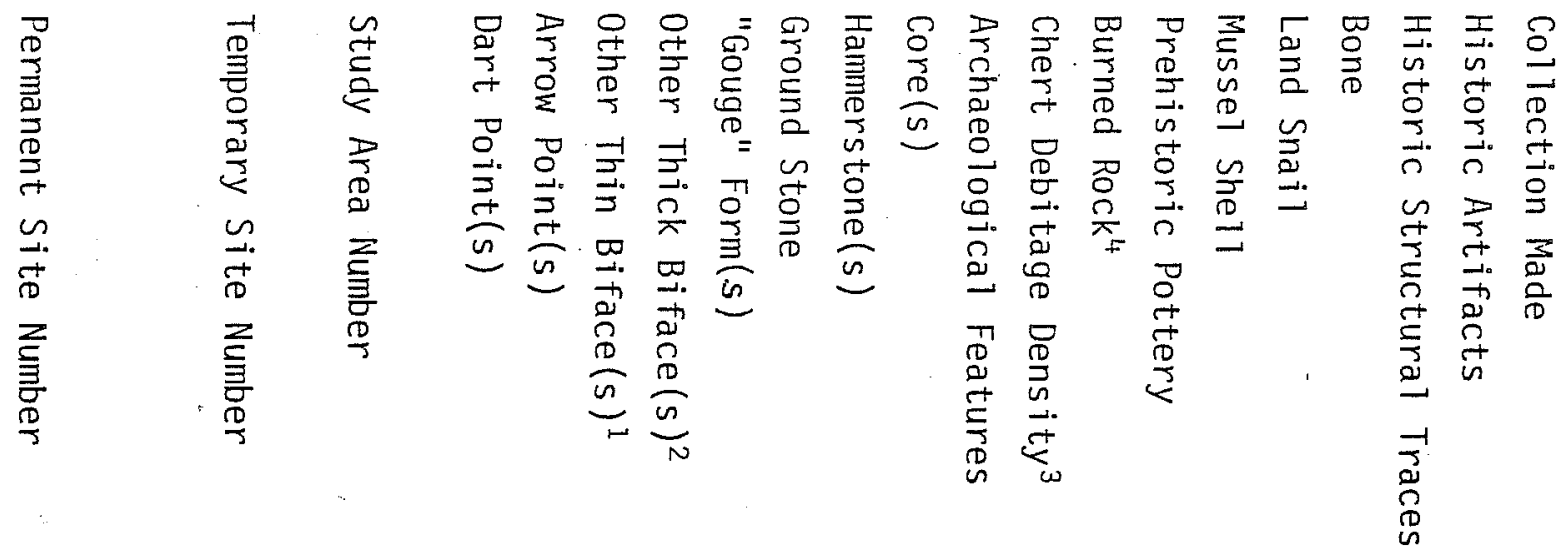

41 MC $253 \quad 38 \quad 8$

47 MC 25439

47 MC $255 \quad 40$

47 MC $256 \quad 41$

41 MC 257. 42

41 MC $258 \quad 43$

41. MC $259 \quad 44$

47 MC $260 \quad 45$

41 MC $261 \quad 46$

41 MC $262 \quad 47$

41 MC $263 \quad 48$

41 MC $264 \quad 49$

41 MC $265 \quad 50$

41 MC 266

41 MC $267 \quad 52$

41 MC 268

41 MC $269 \quad 54$

41 MC $270 \quad 55 \quad 7$

41 MC $271 \quad 56 \quad 7$

41 MC $272 \quad 57 \quad 7$

41 MC 273 69

41 MC $274 \quad 70$

41 MC $275 \quad 71$

41 MC $276 \quad 72$
8

8

8

8

8

8

8

8

7

7

7

7

7

7

7

7

7

7

7

$7 \quad x$

$7 \quad x$

$7 \quad x$

$6 x$

$\begin{array}{ll}x & x \\ x & x\end{array}$

$x \quad x$

$x$

$x \quad x$

$x \quad x \quad x$

$x \quad x \quad x \quad x$

$x$

$x \quad x \quad x$

$x \quad x$

$x \quad x$

$x \quad x$

$x$

$x \quad x$

$x \quad x \quad x$

$x$

$x \quad x \quad x$

$x$

$x \quad x$
$x \quad x$

$x \quad x$

$X \quad L \quad X \quad X$

$x \quad L \quad X \quad X \quad X$

$x$

$X \quad H \quad X \quad X \quad X \quad X$

$x$

$\begin{array}{llll}X & X & L & X\end{array}$

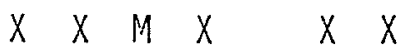

$X \quad M \quad X$

$X \times L$ $x \quad x$

$x \quad M \quad x \quad x \quad x$

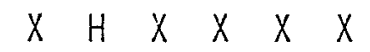

$X \quad X \quad L \quad X \quad X \quad X$

$x \quad M \quad x \quad x \quad x$

$X \quad L \quad X \quad X$

$X \quad L \quad X \quad X \quad X$

$X \quad L$

$X \quad L \quad X$

$x \times$ A $x \quad x \quad x$

$x \times x \times$

$L X$

$X X M X X$

$M X X X X$ 
TABLE 1. (continued)
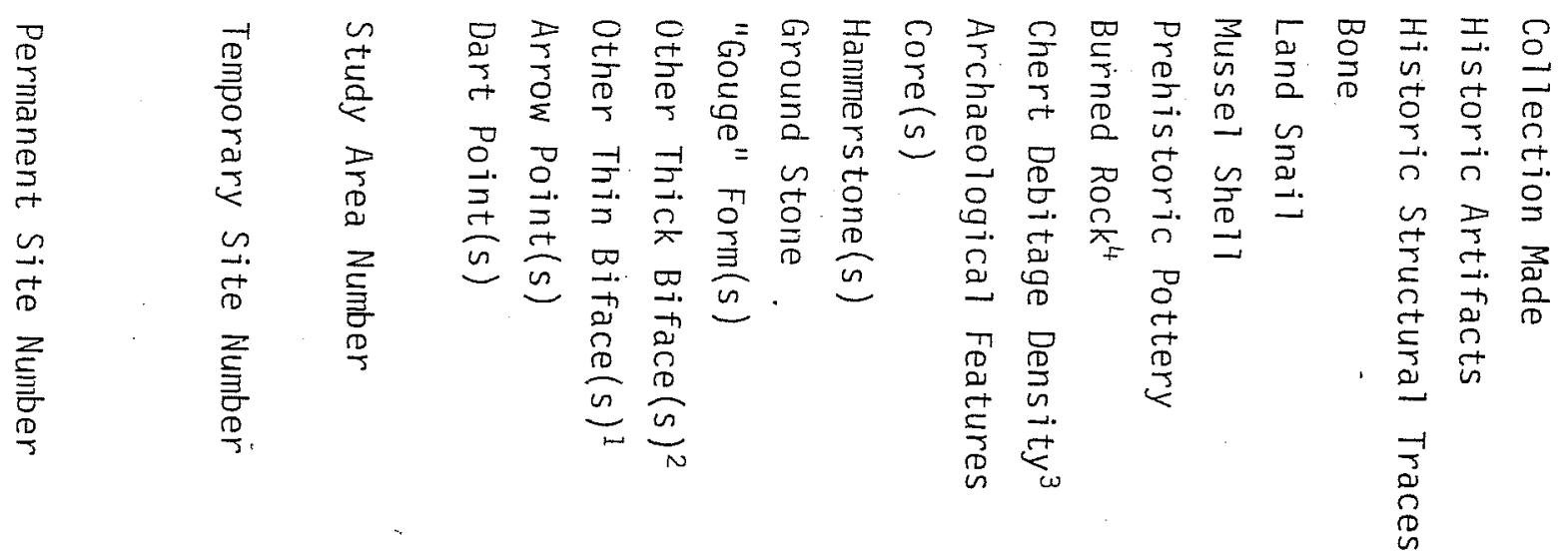

\begin{tabular}{|c|c|c|c|c|c|c|c|c|c|c|c|c|c|c|c|c|c|c|}
\hline 41 MC 277 & 73 & 6 & ! & & $x$ & $x$ & & & $x$ & & M & $x$ & & $x$ & $x$ & & & \\
\hline 47 MC 278 & 74 & 6 & & & $x$ & & & $x$ & $x$ & $x$ & $L$ & $x$ & & $x$ & & & & \\
\hline 47 MC 279 & 75 & 6 & & & $x$ & $x$ & & & & & $L$ & $x$ & & & & & & \\
\hline 41 MC 280 & 76 & 6 & $x$ & $x$ & $x$ & $x$ & & & $x$ & $x$ & $H$ & $x$ & & $x$ & $x$ & & & $x$ \\
\hline 41 MC 281 & 77 & 7 & & & & & & & $x$ & $x$ & L & & & & & $x$ & $x$ & $x$ \\
\hline 41 MC 282 & 78 & 7 & $x$ & & $x$ & $x$ & & & $x$ & $x$ & $L$ & & & $x$ & & $x$ & $x$ & $x$ \\
\hline 41 MC 283 & 79 & 7 & & & & $x$ & & & $x$ & $x$ & $L$ & & $x$ & & & $x$ & $x$ & $X$ \\
\hline 47 MC 284 & 80 & 7 & & & $x$ & $x$ & & & & $x$ & L & & & & & $x$ & $x$ & $x$ \\
\hline 47 MC 285 & 81 & 7 & $x$ & & $x$ & $x$ & $x$ & & & $x$ & $L$ & $x$ & & $x$ & $x$ & & & \\
\hline 41 MC 286 & 82 & 7 & $x$ & $x$ & $x$ & $x$ & & & & & $M$ & $x$ & $x$ & $x$ & & & & $x$ \\
\hline 41 MC 287 & 83 & 7 & & & & & & & & $x$ & & & & & & $x$ & & \\
\hline 41 MC 288 & 84 & 7 & $x$ & & $x$ & $x$ & $x$ & $x$ & $x$ & & $M$ & $x$ & & $x$. & $x$ & & $X$ & \\
\hline 41 MC 289 & 85 & 7 & & & & $x$ & & & $x$ & & $L$ & $x$ & & & & & $x$ & $x$ \\
\hline 41 MC 290 & 86 & 7 & & & & & & & & $x$ & & & & & & $x$ & $x$ & \\
\hline 41 MC 291 & 87 & $?$ & & & & $x$ & & & & & L & & & & & & $x$ & $x$ \\
\hline 41 MC 292 & 88 & 7 & & & & $x$ & & & $x$ & & L & $x$ & & $x$ & $x$ & & $x$ & \\
\hline 41 MC 293 & 89 & 7 & & & $x$ & $x$ & & & $x$ & $x$ & L & & $x$ & $x$ & $x$ & $x$ & $x$ & $x$ \\
\hline 41 MC 294 & 90 & 7 & $x$ & $x$ & & $x$ & $x$ & $x$ & & & $M$ & $x$ & $x$ & $x$ & & & & $x$ \\
\hline 41 MC 295 & 91 & 7 & & & & & & & $x$ & & $L$ & $x$ & & $x$ & $x$ & & & \\
\hline 41 MC 296 & 92 & 6,7 & & $x$ & & & & $x$ & $x$ & & & & & $x$ & $x$ & & & $x$ \\
\hline 47 MC 297 & 93 & 6,7 & $x$ & $x$ & & $x$ & & & $x$ & & $L$ & $x$ & & & & & & $x$ \\
\hline 41 MC 298 & 94 & 6,7 & $x$ & $x$ & & & & & & & $\mathrm{~L}$ & $x$ & $x$ & $x$ & $x$ & & & $x$ \\
\hline
\end{tabular}

IField estimated under $50 \mathrm{~mm}$ thick.

2Field estimated over $50 \mathrm{~mm}$ thick.

${ }^{3}$ Field impression of density (L=Low, M=Medium, $\left.H=H i g h\right)$.

"Usually of chert, also sandstone and Catahoula tuffstone. 
Field photographs and sketches were made of a sample of artifacts from almost all of the sites. An example of field-sketched artifacts is shown in Figure 15.

In Table 2, there is a compilation of diagnostic artifacts from the prehistoric sites. The table is, Tike Table 1, simply a general indication of diagnostics from the surveyed sites and was compiled to provide chronological information. The point types are based on field examinations.

TABLE 2. TENTATIVE CULTURAL-CHRONOLOGICAL AFFILIATIONS BASED ON DIAGNOSTIC ARTIFACTS

\begin{tabular}{|c|c|c|}
\hline Site & Artifact & Possible Cultural Affiliation \\
\hline 41 LK 234 & Frio-Ensor & Late Archaic* \\
\hline 41 LK 236 & pottery & Late Prehistorict \\
\hline 41 LK 242 & Tortugas & Archaic* \\
\hline 41 LK 243 & pottery & Late Prehistorict \\
\hline 41 LK 246 & Scallorn & Late Prehistoric* \\
\hline 41 LK 247 & Ensor; Tortugas & Late Archaic; Archaic* \\
\hline 41 LK 250 & Langtry & Middle Archaic* \\
\hline 41 LK 251 & Ensor & Late Archaic* \\
\hline 41 LK 252 & Ensor & Late Archaic* \\
\hline 41 MC 234 & Castroville & Middle to Late Archaic* \\
\hline 41 MC 242 & Perdiz & Late Prehistoric* \\
\hline 41 MC 247 & Uvalde or Fairland & Late Archaic* \\
\hline 41 MC 248 & Fairland & Late Archaic* \\
\hline 41 MC 250 & Frio; Catan & $\begin{array}{l}\text { Late Archaic, possibly } \\
\text { Late Prehistoric* }\end{array}$ \\
\hline 41 MC 257 & Ensor & Late Archaic* \\
\hline 41 MC 259 & Frio; Catan & $\begin{array}{l}\text { Late Archaic, possibly } \\
\text { Late Prehistoric*+ }\end{array}$ \\
\hline
\end{tabular}


Table 2. (continued)

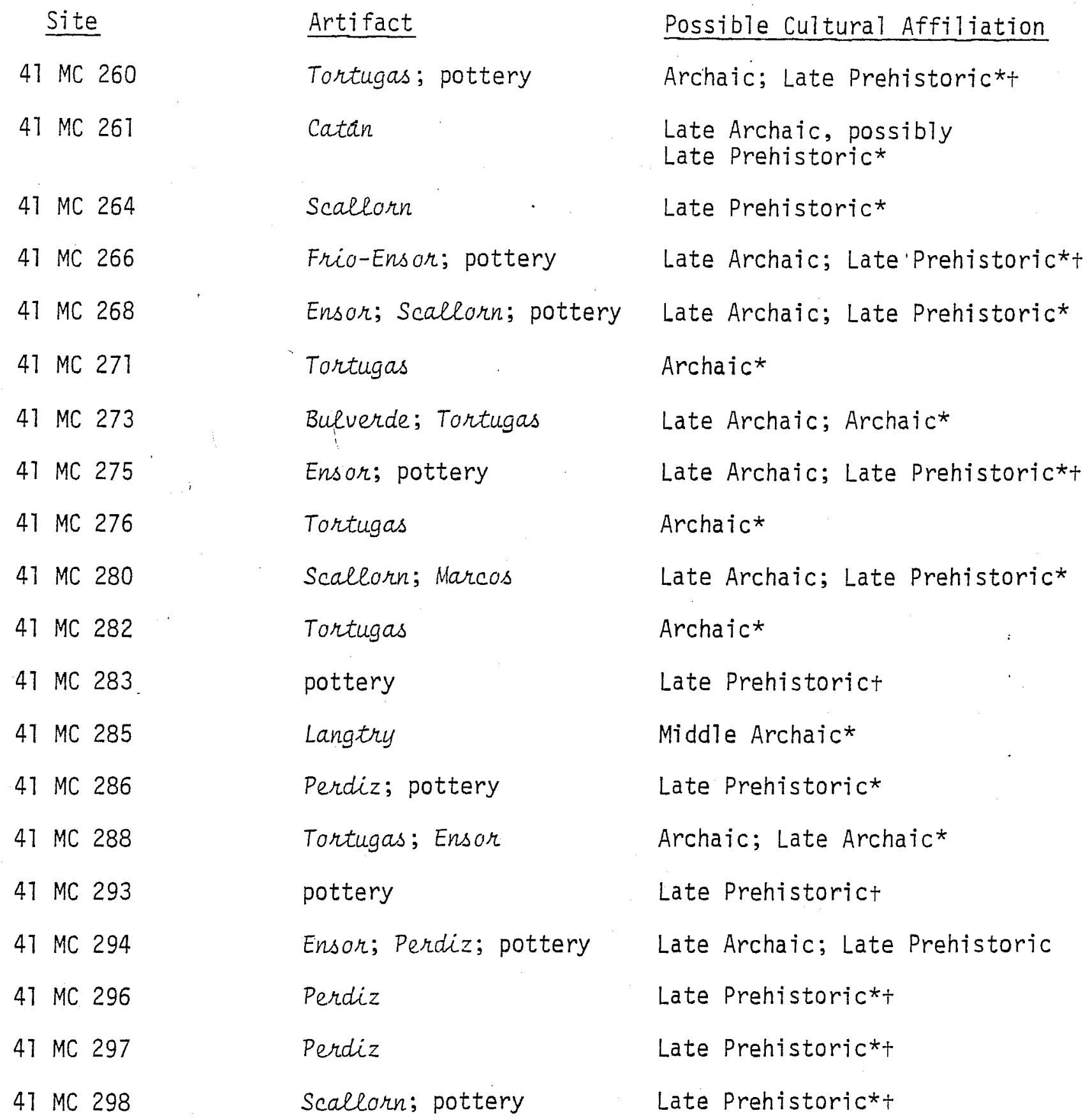


Collected Artifacts

Potentially diagnostic artifacts were collected from 23 sites. Detailed analysis was beyond the scope of this project. Ceramic materials were incorporated by Stephen Black (1981) into his study of prehistoric pottery at Choke Canyon. The historic artifacts were examined in the laboratory by Anne A. Fox, James $E$. Ivey and Lynn Highley and the data derived from them will be incorporated into studies of historic period archaeology at choke Canyon

The following information is in inventory fashion. Surface provenience may be found on artifact bags, CAR inventory sheets, or original site'forms.
41 LK 236
Prehistoric potsherds
41 LK 243
(8)
Prehistoric potsherds, including a cylindrical handle fragment
41 LK 244
Felsite mano, double faceted on one face, single on the other
41 LK 245
Dart point (unidentified)
41 L'K 247
(4)
Dart points/preforms, including Ensor and Tortugas
41 MC 229
White earthenware rim sherd with blue oriental transfer design
White earthenware sherd, glazed; green flower decal design
Possibly late majolica rim sherd, glazed blue on white, fine-grained red core
41 MC 242
Buff earthenware sherd, majolica- like except for very sandy temper, glazed on both sides with a clear- line black, brown, and green design
Beveled knife on biface (Sollberger 1971)
47 MC 260
Broken biface (two pieces)
Prehistoric potsherds
White stone bead, with fine red- streaked inclusions; ca. $130 \mathrm{~mm}$ wide, $65 \mathrm{~mm}$ thick, perforation $50 \mathrm{~mm}$ wide 

41 MC 268
(1)
Prehistoric potsherd
41 MC 275
Prehistoric potsherds
41 MC 280
Possible dart point, Marcos
Arrow points, Scallorn
Biface medial fragment
Thin triangular biface
41 MC 281.
Dark green bottle basal fragments
Dark green bottle body fragment
Small pale green glass vessel fragments
(1) Pressed bottle base
(1) Burned white earthenware sherd with basal flange
(1) White earthenware sherd with fragmentary brown trademark print depicting the top of a crown
(1) Ceramic pipe bowl fragment, buff colored, seamed
(1) Square nail
41 MC 282
Cartridge cases jammed together, .45 cal ibre centerfire, unmarked
(2) Earthenware rim sherds, blue-edged molding on white body
(1) Oriental porcelain sherd
(1) White earthenware rim sherd with a brown line near rim edge
(1) Thin earthenware rim sherd, blue on white, possible sponge ware 
(1) Earthenware sherd; white interior side, exterior embossed white design over green; similar to mocha ware

Earthenware sherds (four fit); buff-colored, glazed exterior with raised motif depicting hand billows, interior white glazed

(1) Bristol-glazed ginger beer bottle fragment

Stoneware sherd, alkaline glaze

(1) Square nail

(1) Flattened iron nail-like object, with wrought 10op end

41 MC 283

41 MC 284

Prehistoric potsherds

White earthenware sherds including one with a trademark remnant ". .. nstone.. . " and one a cylindrical rim sherd with flat-sided exterior

(1) White earthenware sherd with purple transfer design

(1) Stoneware rim sherd, brown-glazed interior side continuing just over exterior side of rim; possible Mexican lead-glaze 017a sherd

Whole brown glass square bottle, cup bottom mold base states:

"ANASARCIN, ACCo, ELIXIR" plus "Steri1"; body seams run up opposite corners, terminate on lower neck, with 7 ipped rim (bottle ca. $18 \mathrm{~cm}$ high, $7 \mathrm{~cm}$ wide)

(1) Whole clear glass bottle, Owen's seam on base, raised letters on flattened side of vessel states: "Groves Tasteless Chill Tonic Prepared by Paris Medicine Co., St. Louis" (bottle ca. $15 \mathrm{~cm}$ high, $6 \mathrm{~cm}$ wide) 
(1)

(1)

(1)

(1)

(1)

(3)

41 MC 286

Brown glass basal bottle fragment, flattened body

Clear glass bottle base; the body wa11 displays a raised trademark of an arm and hammer encircled by a horseshoe, followed by "Property of Torreno Manufacturing Co., San Antonio, Texas"

Clear glass wide-mouth bottle neck, full body molded with several horizontal raised ridges

Clear glass rim fragment (purple tinted)

Clear glass bottle neck fragment with vertical ridges

Aquamarine glass container fragments from preservative-type jars; includes two rims and a lid fragment

Basal sherd of white porcelain

White earthenware sherds including one rim sherd

White earthenware rim sherds with blue trim; trademark on base (offset) states: "La Francaise Porcelain"

Thick stoneware bowl rim sherd; thicker body wall encircles rim. exterior; dark brown glaze on both sides, unslipped on rim edge and lower exterior rim

(1) Rounded stone pebble (child's marble?)

(1) Triangular form biface (possible dart point)

Prehistoric potsherd

Perdiz arrow point

Piece of worked musse? 
41 MC 289

(1) Very smal1 prehistoric biface,

Tozenge-shaped

(6) Various glass bottle necks, exhibit-

ing ful1 mold and applied rim techniques;

several smal1 necks suggest bluing, ex-

tract, or $0 i 1$ vesse1, colors basically

clear

(1)

Round-cornered rectangular vessel

base, clear glass; distinct Owen's

ring contains: "7, Design Patented, 601 , Feb 12 29, N, 77716" circling

a " $T$ " in a triangle trademark

(1) White opaque glass rim sherd

(1) Dark green glass bottle neck rim fragment

(1) Clear glass bottle base; side panel denotes "Gill's botld. purity";

base: "Beeville, Texas"

(1) Brown glass cone-body ink bottle, with flange on shoulders

(2) White earthenware sherds including

a rim sherd with exterior molding

(1) White earthenware rim sherd with

blue transfer floral design

(1) Sample of very thick musse 1 shell

(2) Cartridge casings, both centerfire; one is a "WRA Co., .44 XL," the other "Peters . 38-40"

(1) Iron coffee-grinder machine fragment

41 MC $291 \quad$ (1)

41 MC 293

Fragment of single strand barbed wire, Sunderland Kinked 1884 patent

(3) Dark green glass bottle basal fragments, the largest shows an empontilling mark

(4) Dark green glass fragments, probably related to basal fragments above 
(2) Earthenware rim sherds; molded-edge ware, blue trim on white

(4) Earthenware sherds including two rim sherds; blue sponge pattern on white with thin green line running near rim edges

(2) Earthenware sherds, transfer-printed flown blue ware; one has a white side, the opposite blue showing an oriental motif; the other sherd has a blue design on both sides

(1) Large earthenware rim sherd with blue transfer-printed design on white body; body form is angular sided

(1) Smal1 white earthenware sherd with a fine pale blue line

41 MC 294

Various earthenware sherds, a11 white

Earthenware sherds; white bodies with exterior hand-painted designs, including a purple rim line and green and biue floral (?) designs

(1) Bristol-glazed ginger beer bottle sherd

(1) Horseshoe

(2) Square nails

(1) Metal button

(3) Various metal scraps

(1) Groundstone fragment, sandstone

(2) Prehistoric potsherds

(1) Perdiz arrow point

(1) Ensor dart point

(1) Triangular biface, possible dart point

(3) Bifaces

(1) Flake end scraper 


\begin{tabular}{|c|c|c|}
\hline & (1) & $\begin{array}{l}\text { Fine-grained devitrified rhyolite } \\
\text { hammerstone-mano }\end{array}$ \\
\hline & (1) & Triangular biface fragment \\
\hline & (1) & Guadalupe biface \\
\hline & (6) & Biface fragments \\
\hline & (1) & Thick biface \\
\hline & (1) & Thick mussel shell sample \\
\hline 41 MC 296 & (1) & Flake end scraper \\
\hline & (1) & Thin biface distal fragment \\
\hline & (1) & Possible arrow point preform \\
\hline & (1) & Arrow point with broken base \\
\hline & (1) & Perdiz arrow point \\
\hline 41 MC 297 & (2) & Thin bifaces (possible preforms) \\
\hline . & (1) & Thin biface fragment \\
\hline & (2) & Thick unifaces, probable scrapers \\
\hline & (1) & Arrow point fragment \\
\hline & (1) & Palmwood test cobble \\
\hline 41 MC 298 & (1) & Prehistoric potsherd \\
\hline & (1) & Scallorn arrow point fragment \\
\hline Isolated Find \#19 & (5) & Prehistoric potsherds \\
\hline Isolated Find $\# 20$ & (1) & Dart point \\
\hline
\end{tabular}




\section{SITE DESCRIPTIONS}

The following descriptions provide general information on the 94 recorded sites. The official site form, the original field form, the Bureau 1:8000inch maps, and daily notes of the crew should be consulted for more detail (available at CAR-UTSA). Two divisions follow: Prehistoric Site Descriptions and Historic Site Descriptions which include prehistoric sites with historic components. Additional information is provided in charts.

Certain archaeological "shorthand" is employed in the site descriptions that follow. Feet are indicated by ( 1 ); meter is abbreviated as $\mathrm{m}\left(\mathrm{or} \mathrm{m}^{2}\right)$. Similarly the comment that "land snail" is present at a site indicates that the survey team observed species of land snails, principally Rabdotus, in varying numbers. Under "comment," the term "minimal" indicates the site has little or no potential for future investigations. The quantities of specimens that were observed but not collected are estimated by a \pm approximation. "Comments" are offered where appropriate.

Table 1, provided earlier, presents a concise listing of site traits. The ARCHAEOLOGICAL FEATURE category refers almost exclusively to burned rock or mussel shel1 concentrations, probably two of the most frequent non-portable prehistoric manifestations of the area. The term BONE refers to any bone presence considered to be of appropriate age or context (e.g., aboriginal). These were often sma11, unidentifiable fragments.

Site Descriptions: Prehistoric

41 LK 231 (UTSA 1)

Location: Site is on the gentle valley wall, sitting on a knoll formed by the $200^{\prime}$ contour with the Frio River $1.2 \mathrm{~km}$ to the north and a secondary drainage $600 \mathrm{~m}$ south.

Area: $1800 \mathrm{~m}^{2}$

Elevation: $202^{\prime}$

Environment: Pasture, brushland; sand/alluvium.

Evidence: Scattered flakes, burned rock fragments, mussel fragments, land snails, several crude biface fragments.

Comment: Minimal.

41 LK 232 (UTSA 2)

Location: Site runs just along the north side of a secondary drainage.

Area: $37,500 \mathrm{~m}^{2}$ 
Elevation: $190^{\circ}$

Environment: Pasture, recent clearing; stock tank with light brush; sand/ a) 7 uvium.

Evidence: Light to moderate scatter of burned chert and tuff stone, flakes, 1and snails, mussel fragments; also 1 biface and 2 fragments, ground stone fragment, core fragment; quartz and palmwood cobbles noted.

\section{LK 233 (UTSA 3)}

Location: On a very slight rise just east of a secondary drainage; lower valley wall.

Area: $7500 \mathrm{~m}^{2}$

Elevation: $196^{\prime}$

Environment: Pasture, weeds; cleared; sand/alluvium.

Evidence: Moderate scatter of burned chert and tuff stone, flakes, land snails, \pm 6 cores, a small thin biface, biface fragment, and quartz cobble.

\section{LK 234' (UTSA 4)}

Location: This site is on a s7ight rise just west of a secondary drainage; lower valley wall.

Area: $4200 \mathrm{~m}^{2}$

Elevation: 194'

Environment: Grass, weeds a few retama; sand/alluvium.

Evidence: Relatively heavy scatter of flakes, burned chert and tuff stone, mussel fragments, land snail, 3-4 thin bifaces, \pm 6 cores, a Frio-Ensor dart point, hammerstone; sandstone fragments also present.

\section{LK 235 (UTSA 5)}

Location: Site is on a low rise of the floodplain; the Frio River is nearby (Fig. 8,a).

Area: $3250 \mathrm{~m}^{2}$

Elevation: 180'

Environment: Grass, weeds; riverine hardwoods nearby; sand/alluvium. 


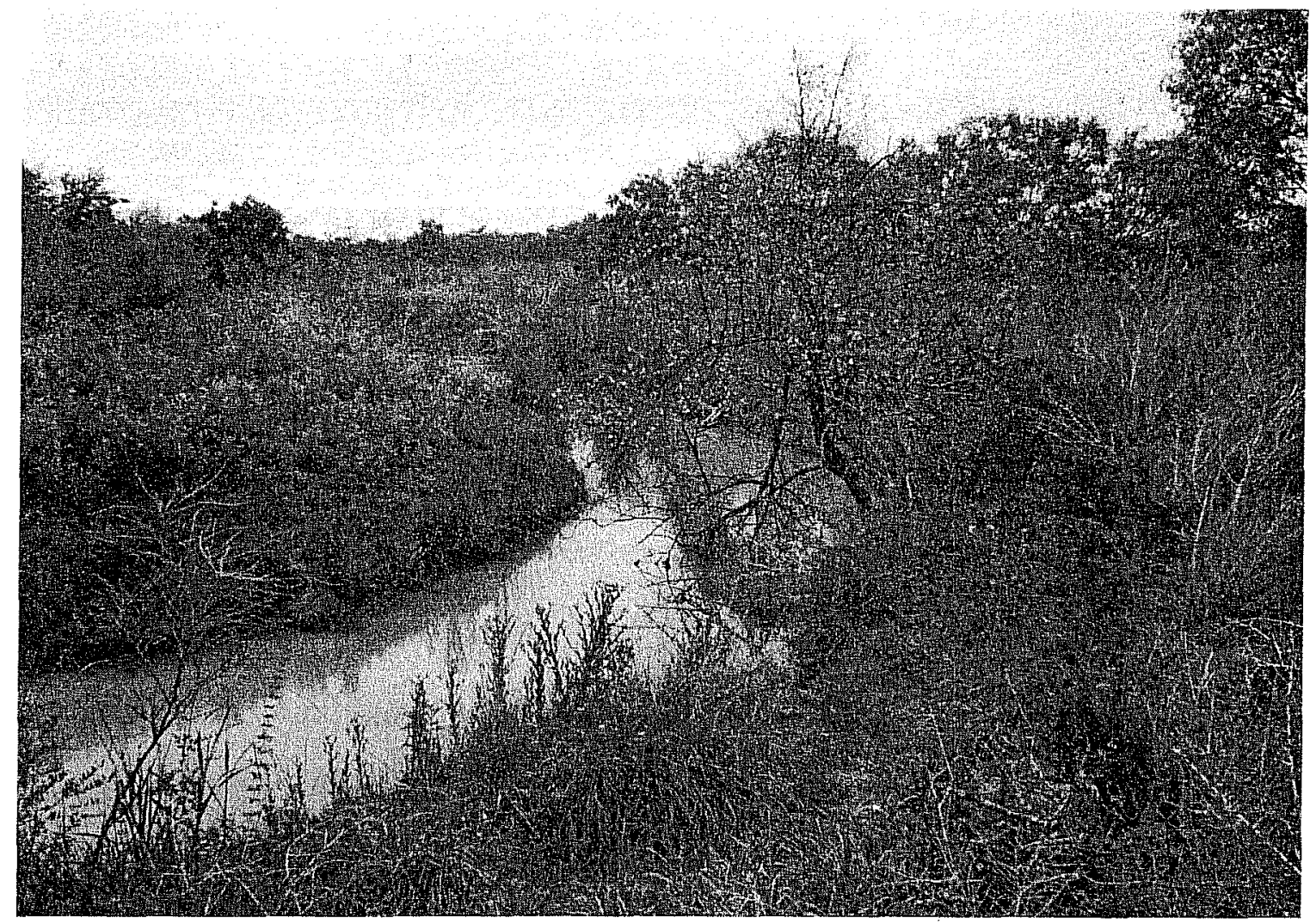

a

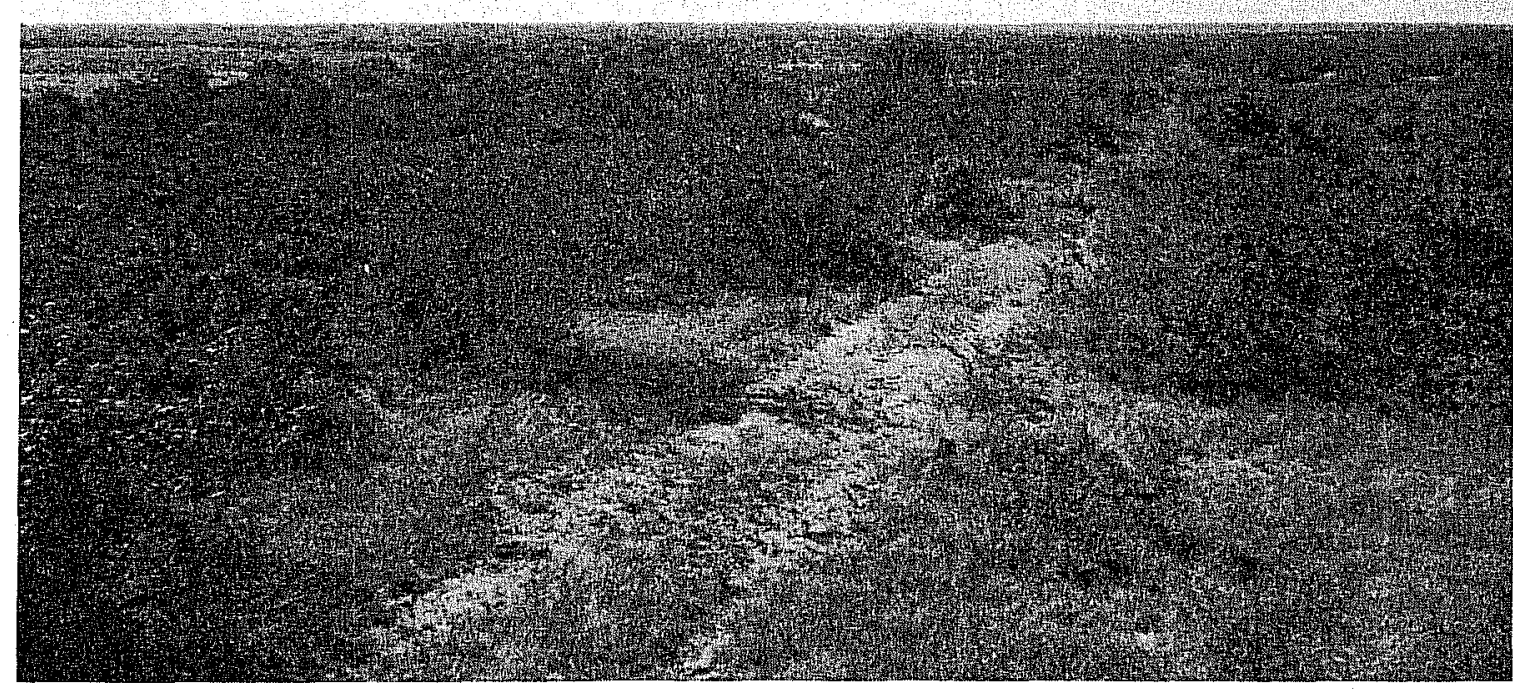

b

Figure 8. Study Areas 4 and 5. a, Study Area 4. (view west of Salt Creek water hole, just north of 41 MC 235); b, Study Area 5 (general view east 
Evidence: Light scatter of flakes, burned chert, a few ground stone fragments, land snails and mussel fragments.

Comment: 41 LK 74 and 41 LK 24 (on a prominent hi11) are nearby. The site location is interesting, with the topographic distinction seen only on Bureau $2^{\prime}$ contour maps.

41 LK 236 (UTSA 6)

Location: This site runs for over $500 \mathrm{~m}$ along the immediate, southern side of the Frio River.

Area: $\quad 35,000 \mathrm{~m}^{2}$

Elevation: $170^{\prime}$

Environment: Pasture and lush riverine hardwoods, vines, etc.; sand/alluvium.

Evidence: Light scatter of flakes, burned chert, and mussel fragments; also 2 Late Prehistoric potsherds, ground sandstone fragment, several cores, crude biface, trace of land snails. One mussel concentration showed in the levee bank; evidence is seen exposed along the river bank on the terrace above.

\section{LK $237^{\circ}$ (UTSA 7)}

Location: Site is on gentle slope ascending west of small secondary drainage; lower valley wall.

Area: $1120 \mathrm{~m}^{2}$

Elevation: 200'

Environment: Brushland; site revealed by sendero sand/10am.

Evidence: Light scatter of sma11 burned chert fragments, mussels, land snails, flakes; also a flake of petrified wood and a biface fragment.

Comment: This site was in a very small area; possibly relates to 41 LK 238 nearby which was more eroded.

\section{LK 238 (UTSA 8 )}

Location: West of, and cut by, a secondary drainage; lower valley wall (Fig. 9,b).

Area: $18,000 \mathrm{~m}^{2}$

Elevation: 194-199' 


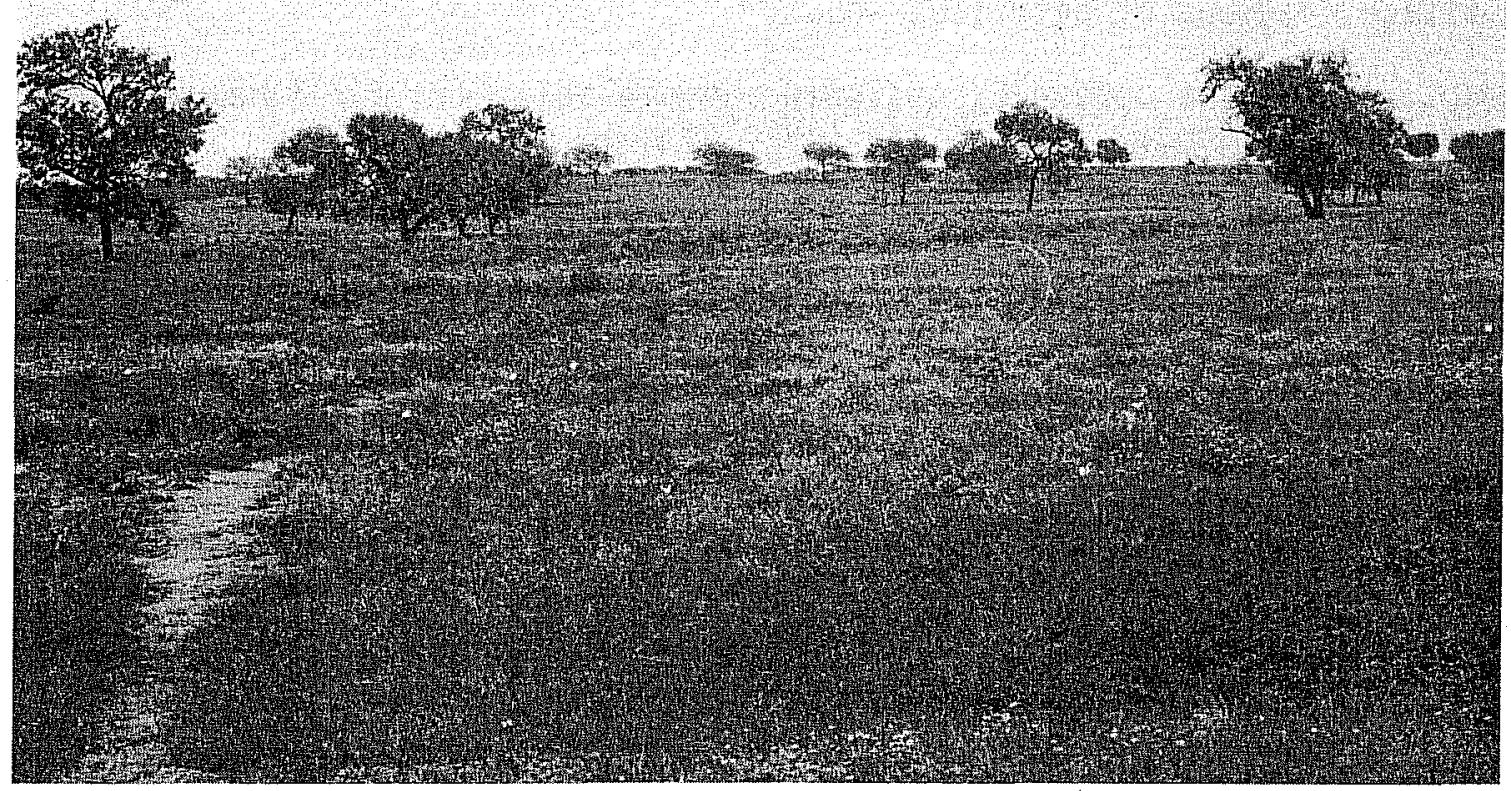

a

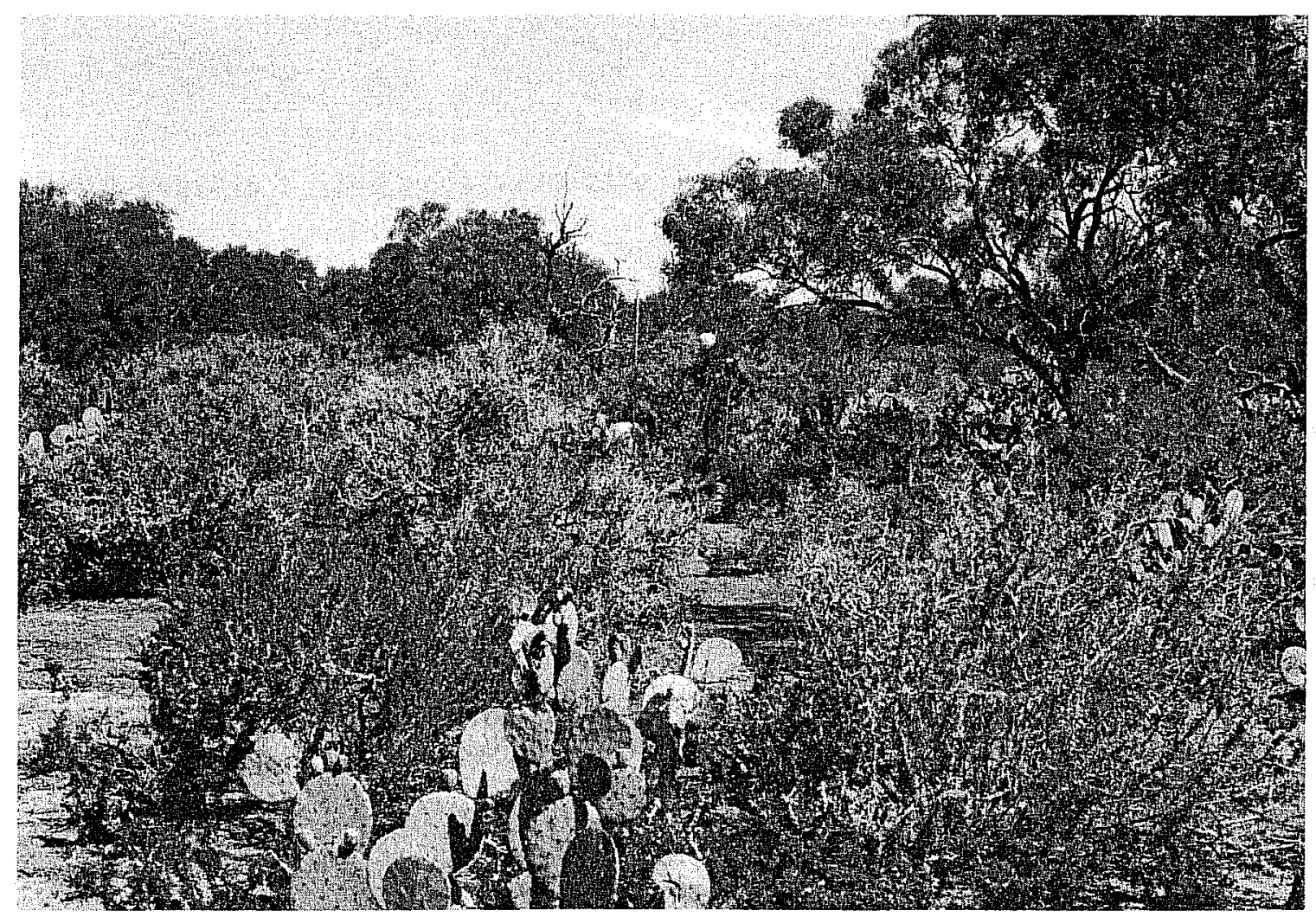

b

Figure 9. Study Area 2. a, view southeast of 41 LK 27 extension; b, view northwest of 41 LK 238. 
Environment: Brushland, with some open areas, sparse grass, and sheet washing; sand/alluvium.

Evidence: Light scatter of flakes with some burned chert, a few land snails; one biface fragment of petrified wood.

Comment: This site appeared scattered and deflated; 41 LK 237 nearby may contain related evidence, with a thin layer of soil protecting it.

41 LK 239 (UTSA 11)

Location: Site is on the northern slope of the prominent upland ridge separating the Frio River to the north and the Nueces River to the south (Fig. 10,a).

Area: $\quad 240,000 \mathrm{~m}^{2}$

Elevation: $225-265^{\prime}$

Environment: Brushland; alluvial soils with abundant chert, petrified wood and quartzite gravels; tuff sandstone outcrops.

Evidence: Numerous flakes and cores (25+), but thiniy scattered; little or no burned rock.

Comment: Area met site definition, but the evidence is highly scattered with vague boundaries.

41 LK 240 (UTSA 13)

Location: Site is on upper valley wall with only ephemeral drainages nearby, including a gully cutting the area.

Area: $2400 \mathrm{~m}^{2}$

Elevation: $230^{\prime}$

Environment: Brushland, senderos; alluvium, tuffaceous outcrops, and smal1 amount of gravel.

Evidence: Light scatter of flakes, a few pieces of burned chert; ground stone fragment, 3 crude bifaces.

41 LK 241 (UTSA 14)

Location: Upland and upper valley wal1; a secondary drainage originates $250 \mathrm{~m}$ eastward.

Area: $\quad 120,000 \mathrm{~m}^{2}$ 


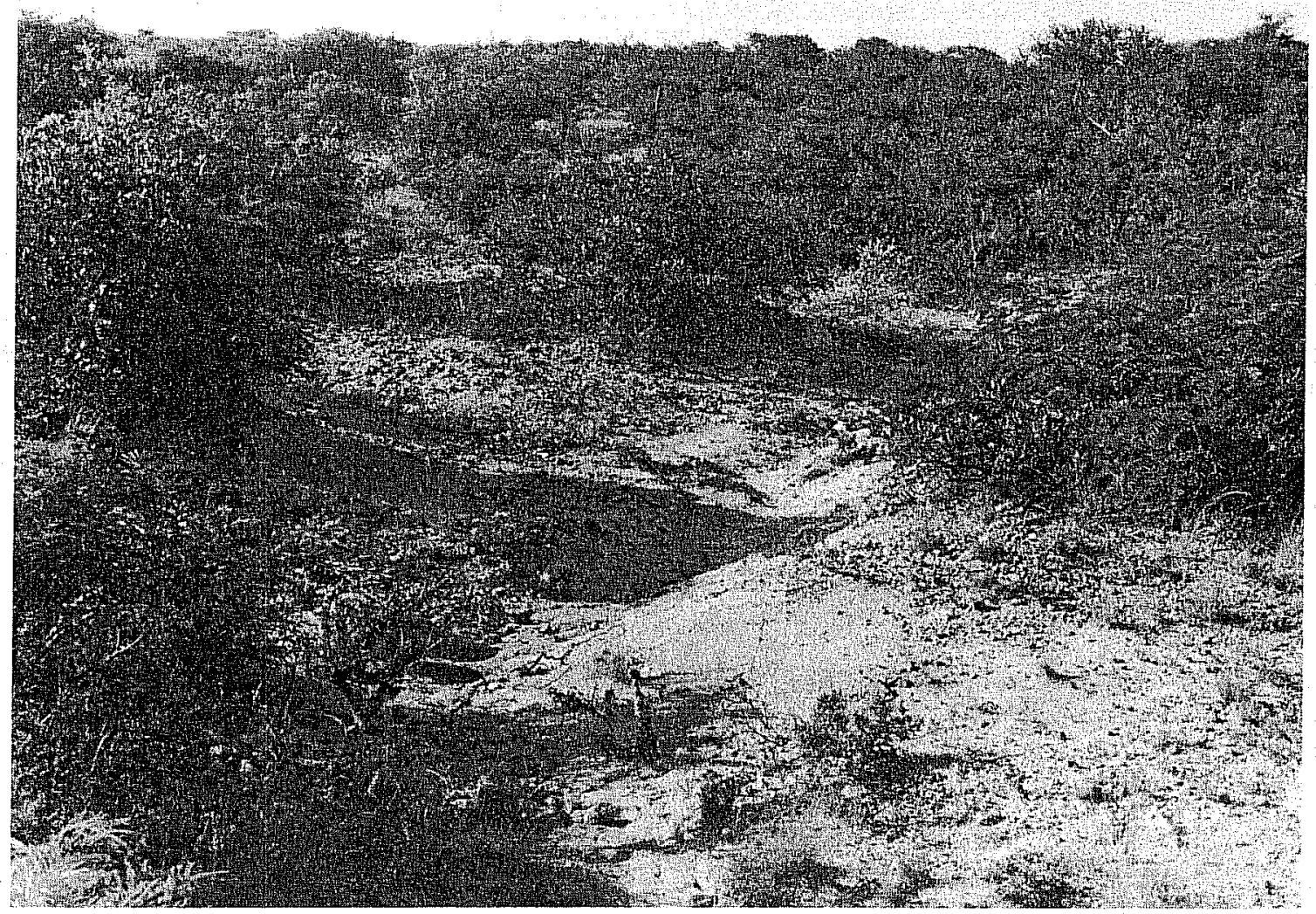

a

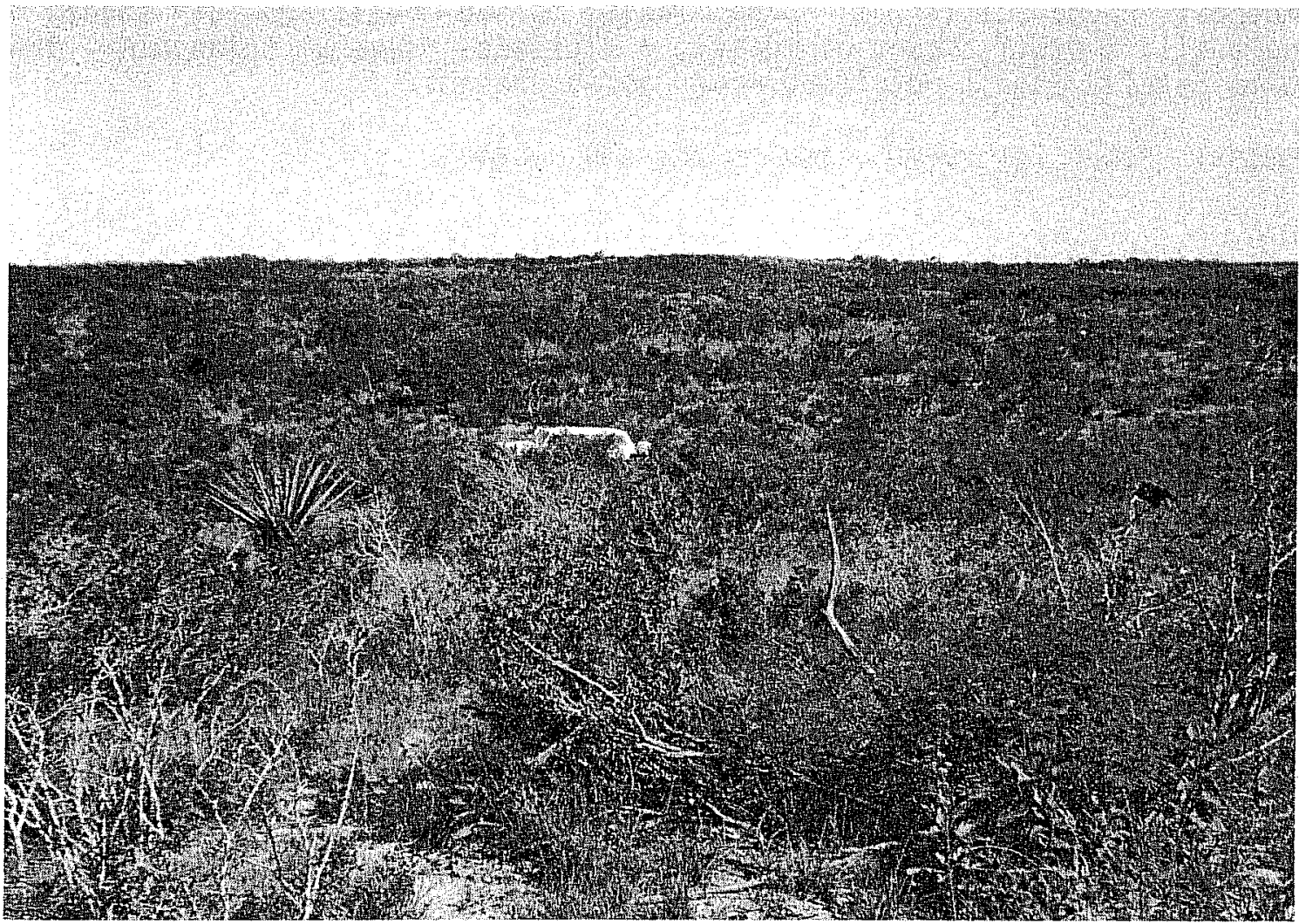

b

Figure 10. Study Areas 1 and 3. a, Study Area 1 (view southwest of 41 LK 239); b, Study Area 3 (view northwest of 41 LK 244). 
Elevation: $230-270^{\prime}$

Environment: Brush; al7uvium with tuffaceous outcrops; abundant gravel.

Evidence: Large area flake scatter, with numerous cores; 10 thick and severa 1 thin bifaces, one Guadalupe tool, one Clear Fork tool; density varies great7y, being highest in the eroding gullies on the lower slope. On the flat top of the upland hill, little is seen. A burned rock feature has been exposed where Highway 72 rerouting work has cut a road bank.

Comment: This site area as determined may not reflect any concentration of past activity by its north-south axis.

\section{LK 242 (UTSA 15)}

Location: Site is located near origins of a minor drainage beginning high on the valley wall, near the divide between the Nueces and Frio Rivers (exposed to the latter).

Area: $30,000 \mathrm{~m}^{2}$

Elevation: $230^{\prime}$

Environment: Brush, grasses; alluvium/loam, trace of cultural debris noted in gravel.

Evidence: Large scatter of eroded flakes, burned chert, and tuff stone, much land snail, a small amount of mussel; \pm 3 bifaces (several triangular forms, 1 with beveled edge); petrified wood debris present.

Comment: Potential quarry area in uplands nearby.

41 LK 243 (UTSA 58)

Location: Southern exposure of lower val1ey wa11, $150 \mathrm{~m}$ north of Opossum Hollow, $1.2 \mathrm{~km}$ northeast of Frio River.

Area: $39,000 \mathrm{~m}^{2}$

Elevation: 212-228'

Environment: Brush sparse grasses; alluvium/loam and gravel; petrified wood and chert pientiful.

Evidence: Light flake scatter with 3 hearths of burned chert evident; other scattered burned chert exists; also includes a biface fragment, cores, land snail, trace of mussel; 1 unusual double-faceted mano of igneous rock. 
41 LK 245 (UTSA 60)

Location: Site is in high drainage on valley wa11; Opossum Hollow $960 \mathrm{~m}$ south, Frio River $1.76 \mathrm{~km}$ south-southwest.

Area: $7000 \mathrm{~m}^{2}$

Elevation: $225-230^{1}$

Environment: Brush, sparse grass; al7uvium/clay; abundant chert, petrified wood, graveT.

Evidence: Light flake scatter with areas of heavily burned chert; cores plentiful; land snails, trace of mussel; the burned rock has a "midden" appearance. There may be 3 distinct scatters, each several meters wide; 3 thick bifaces (1 of quartzite), several fragments, 1 dart point.

Comment: Upslope areas are fairly intact; downslope erosion is severe.

\section{LK 246 (UTSA 61)}

Location: Site is at base of valley wa11; Opossum Hollow is $780 \mathrm{~m}$ south, Frio River $1.44 \mathrm{~km}$ south.

Area: $18,000 \mathrm{~m}^{2}$

Elevation: 194-208'

Environment: Upland brush; alluvium/loam, clay, plentiful gravel.

Evidence: Moderate flake scatter with some burned chert and land snail present. Quartzite and petrified wood debitage occurred. A Scallorn point, 3 thin bifaces, and more than 12 cores were noted. Low density evidence tapered northward following up the drainage.

Comment: One discrete hearth was observed.

41 LK 247 (UTSA 62)

Location: Site is exposed by erosion in drainage of valley slope.

Area: $8400 \mathrm{~m}^{2}$

Elevation: $200-220^{\prime}$

Environment: Upland brush, alluvium/loam; heavy gravel deposits with some petrified wood. 
Evidence: Moderate to heavy evidence eroded out and down the southern side of the drainage walls. Flakes, mussel shell, many land snails and burned rock is. seen. Also, an Ensor point, Tortugas point, 2 other unidentified bifaces (2 of chert, 1 of tuff stone) were noted in profile; at the drainage origin, one hearth was $1 \mathrm{~m}$ deep and below it, at $2 \mathrm{~m}$, a flake was observed within a distinctive gravel stratum.

Comment: This site was identified only in the erosional profile of the relatively small, narrow drainage, with erosion quite severe.

\section{LK 248 (UTSA 63)}

Location: Site is in upper drainage of valley slope.

Area: $1800 \mathrm{~m}^{2}$

Elevation: $205-220^{\prime}$

Environment: Upland brush; alluvium/loam; heavy gravel deposits, some petrified wood.

Evidence: Very much like 41 LK 247, but less material, more disturbance; light flake scatter, burned chert, few mussel fragments, 2-3 cores, land snails present.

Comment: Earlier survey activity at 41 LK 52 (nearby to the southeast) included some surface collection for this gully: 2 bifaces, 1 biface fragment, 1 core biface.

41 LK 249 (UTSA 64)

Location: Site is along secondary drainage running south, entering Opossum Hollow $2.4 \mathrm{~km}$ south.

Area: $\quad 12,500 \mathrm{~m}^{2}$

Elevation: $200^{\prime}$

Environment: Brush; alluvium/loam.

Evidence: A light flake scatter and burned chert fragments cover a large area; one thick biface was noted.

Comment: Minima1. 
41 LK 250 (UTSA 65)

Location: Upper drainage of valley, in gully system.

Area: $2400 \mathrm{~m}^{2}$

Elevation: $226-240^{\prime}$

Environment: Brush; alluvium/loam; gravel outcrops nearby.

Evidence: Site exhibits moderate to heavy scatter of flakes, mainly, exposed in the gully; also a thin biface, a thick biface, a Langtry dart point fragment, \pm 6 cores, a single-faceted ground stone artifact, bone fragment, a few mussel fragments, and land snails. Material is $1 \mathrm{~m}$ or more below surface exposed in gully profile.

\section{LK 251 (UTSA 66)}

Location: Site is on upper valley wall and upland, east of a north-south drainage leading to Opossum Hollow $2.4 \mathrm{~km}$ south; the Frio River is over $3.2 \mathrm{~km} \cdot \mathrm{south}$.

Area: $25,000 \mathrm{~m}^{2}$

Elevation: $240-290^{\prime}$

Environment: Upland brush; alluvium/clay, abundant gravel.

Evidence: Light flake scatter over a large area; many flakes with cortex surfaces; 15-20 thick bifaces, numerous cores including tested cobbles; one possible dart point or preform; quartzite and petrified wood present; Curtis Dusek reports an Ensor point from this site; a "low density scatter" (according to CRI definition) surrounds much of the site.

Comment: This site is most similar to 41 LK 252.

41 LK 252 (UTSA 67)

Location: Site is on upper valley wal1/uplands, east of secondary drainage leading to Opossum Hollow $2.4 \mathrm{~km}$ south; Frio River is over $3.2 \mathrm{~km}$ south.

Area: $25,000 \mathrm{~m}^{2}$

Elevation: $250-270^{\prime}$

Environment: Upland brush; alluvium/clay, gravel outcrops, fossil oyster, petrified wood, quartzite. 
Evidence: Light flake scatter with some areas of burned chert, 5 thick bifaces, possibie dart point fragment, hammerstone of quartzite or other material with crystal inclusions--circled with wear, about 20 cores; Curtis Dusek also reports an Ensor point from this site; low density. scatters seem to be whereever gravel is; an area of concentrated burned chert exists, possibly a hearth.

Comment: This site is most similar to 41 LK 251.

\section{LK 253 (UTSA 68)}

Location: Site is along a large secondary drainage running south to Opossum Hollow 2.4-3.2 km away.

Area: $\quad 13,000 \mathrm{~m}^{2}$

Elevation: $226^{\prime}$

Environment: Brush; alluvium/clay.

Evidence: Light to moderate flake and burned chert scatter; 10 thick bifaces, 4 thin bifaces, piece of ground sandstone, land snails.

41 MC $228^{\circ}$ (UTSA 9)

Location: Site is on upper valley wall/upland, near the ridge separating the Frio and Nueces River drainages; the Frio River is $4.48 \mathrm{~km}$ north; no minor drainage nearby.

Area: $40,000 \mathrm{~m}^{2}$

Elevation: $230^{\prime}+$

Environment: Cultivated field; alluvium/loam, some natural gravels, petrified wood, tuff stone noted.

Evidence: Light scatter of flakes and burned chert was observed, with 3 bifaces and a "gouge"; cores present (one of petrified wood); the rerouted State Highway 72 cut bank showed additional material.

41 MC 231 (UTSA 16)

Location: Site is on valley wall slope with the Frio River about $1.6 \mathrm{~km}$ to the north; it is on northeast exposure of a slope just west of a branch of Salt Creek.

Area: $1500 \mathrm{~m}^{2}$

Elevation: $225^{\prime}$ 
Environment: Mesquite, cactus, grasses; alluvium/loam, petrified wood abundant in area.

Evidence: This site has a light flake scatter and little if any burned rock; 4 thick bifaces ( 2 of chert, 1 of petrified wood, 1 of palmwood), sandstone fragment, land snails.

41 MC 232 (UTSA 17)

Location: Drainage bottom of Salt Creek, tributary to the Frio River, about $1.6-2.4 \mathrm{~km}$ north.

Area: $10,000 \mathrm{~m}^{2}$

Elevation: 190'

Environment: Some brush and grass with much bare ground; alluvium/clay.

Evidence: Site consists of a moderate scatter of flakes and burned rock (mainly sandstone), some petrified wood debitage, 2 thick bifaces, scattered hearths.

41 MC 233 (UTSA 18)

Location: Low valley wall exposure west of Salt Creek tributary to Frio River, about $1.6 \mathrm{~km}$ north.

Area: $10,000 \mathrm{~m}^{2}$

Elevation: $220-230$ '

Environment: Brush, grass, cactus; alluvium/loam.

Evidence: Light flake scatter with a few cores, some burned chert, mussel traces, a few land snails, and a biface fragment.

Comment: Minimal.

41 MC 234 (UTSA 19)

Location: Low drainage slope (valley wal1), just west of Salt creek fork, tributary to the Frio River about $1.6 \mathrm{~km}$ north.

Area: $20,000 \mathrm{~m}^{2}$

Elevation: $210-220^{\prime}$

Environment: Brush, cactus, yucca, grasses; alluvium/10am. 
Evidence: Moderate scatter of flakes with numerous bifaces, mussel fragments, some burned chert, sandstone present, land snail trace, \pm 3 cores, 3 dart points including a castroville-like specimen, 2 thin bifaces, 1-2 thick bifaces; one mussel had a drilled hole in its umbo.

41 MC 235 (UTSA 20)

Location: Floodplain or lowest slope by secondary drainage junction (Salt Creek); Frio River as $1.6 \mathrm{~km}$ north (Fig. 10,a).

Area: $\quad 12,500 \mathrm{~m}^{2}$

Elevation: $200^{\prime}$

Environment: Brush, grasses; alluvium/loam.

Evidence: Light scatter of flakes (including palmwood specimens), a few cores, some burned chert fragments, sandstone present, biface distal fragment, also a possible sandstone hearth being revealed by erosion.

41 MC 236 (UTSA 21)

Location: Floodplain close to creek bottom; Salt Creek drainage runs to the Frio River about $1.6 \mathrm{~km}$ north.

Area: $750 \mathrm{~m}^{2}$

Elevation: 113'

Environment: Brush, grasses; alluvium/loam.

Evidence: Light flake scatter with some burned chert, a core, 2 possible utilized flakes, and a biface.

Comment: Minima 1.

41 MC 238 (UTSA 23)

Location: Terrace edge west of north-south river slough, probabiy a cut-off channel from the Frio River, now running north-south about $400 \mathrm{~m}$ to the east.

Area: $\quad 30,000 \mathrm{~m}^{2}$

Elevation: $200^{\prime}$

Environment: Brush, cleared land with grasses, weeds; alluvium/loam. 
Evidence: A moderate to heavy flake and mussel scatter runs as a narrow band over $500 \mathrm{~m}$ distance along the levee; one possible sandstone feature, a small dart point, 7 thick bifaces, a thin biface, a small triangular "gouge," \pm 15 cores, 2 pieces ground sandstone, land snails, sma 71 burned chert fragments.

\section{MC 239 (UTSA 24)}

Location: Upper valley wall (ridge slope), south and east of an upper secondary drainage running east to the Frio River about $1.6 \mathrm{~km}$ away; Frio River "Loop" also is $1.6 \mathrm{~km}$ northwest.

Area: $10,000 \mathrm{~m}^{2}$

Elevation: $240-255^{\prime}$

Environment: Upland brush, sparse grasses; alluvium/loam, chert grave1, tuffaceous stone.

Evidence: Light flake scatter, 2 thin bifaces, probable dart point (Tortugas), a thick biface, \pm 12 cores (some bifacial, some test nodules), cortex flakes common; palmwood and petrified wood present.

Comment: Minimal site, set within an area of widespread low density evidence (gravel upland ridges); location also was just above 230' elevation and therefore not within the intensive survey.

41 MC 240 (UTSA 25) (see Site Descriptions: Historic)

41 MC 241 (UTSA 26)

Location: Terrace bank along Frio River, slough-like drainage.

Area: $3500 \mathrm{~m}^{2}$

Elevation: $200^{\prime}$

Environment: Mesquite trees, grasses, hardwood; alluvium/10am.

Evidence: Moderate scatter of flakes, 5 ground sandstone fragments, a thick biface, several cores; mussel fragments are present and extend along the bank slopes beyond site limits; land snail present.

Comment: Deer hunters' camp house nearby; relic collecting very likely.

41 MC 242 (UTSA 27)

Location: Slough bank west of primary drainage; Frio River $300-400 \mathrm{~m}$ to the east. 
Area: $15,000 \mathrm{~m}^{2}$

Elevation: 196-202'

Environment: Brush, grasses ard hardwood; al7uvium/10am.

Evidence: Moderate flake scatter, including a beveled "knife" of Late Prehistoric style, a Perdiz arrow point, 5 thin bifaces, 8 cores, plentiful mussel and land snail. Sandstone hearth visible in eroded road.

41 MC 243 (UTSA 28)

Location: Bank-peninsula west of north-south slough which is part of a primary drainage to the Frio River $400 \mathrm{~m}$ east.

Area: $4000 \mathrm{~m}^{2}$

Elevation: $190-200^{\prime}$

Environment: Brush, persimmon, grasses; alluvium/loam.

Evidence: Light to moderate flake scatter; 3 thin bifaces, 6 pieces of ground sandstone, several cores, plentiful mussel with several concentrations; observed 1 ground stone had abraded grooves.

41 MC 244 (UTSA 29)

Location: Terrace bank overlooking slough drainage, primary to the Frio River 600 m east.

Area: $7500 \mathrm{~m}^{2}$

Elevation: $200^{\prime}$

Environment: Brush and grasses; alluvium/loam.

Evidence: Light flake scatter with some burned chert and sandstone, 2 thin bifaces; \pm 6 cores, main concentration is small $(10 \times 10 \mathrm{~m})$.

41 MC 245 (UTSA 30, prehistoric component)

Location: Low terrace bank over slough-1ike primary drainage to the Frio River $600 \mathrm{~m}$ east.

Area: $6250 \mathrm{~m}^{2}$

Elevation: $194-200^{\prime}$

Environment: Scattered brush, grasses; alluvium/loam. 
Evidence: Light flake scatter with some mussel and burned sandstone, concentrated on two low "knolls" of the 200-foot contour bank; historic structure on site.

Comment: Minimal prehistoric evidence; relic collecting likely.

41 MC 246 (UTSA 31)

Location: Site is on an "island" with a flowing Frio River meander on the southern side and a slough loop encircling the remainder (Fig. 11,a).

Area: $45,000 \mathrm{~m}^{2}$

Elevation: $235^{\prime}$

Environment: Moderately thick brush with grass clearings; alluvial soit.

Evidence: Light flake scatter, several cores, large thick biface (utilized edge?), 3 thin bifaces, sandstone possibly from disturbed hearths; (some evidence including the sandstone comes from an eroding peninsular bank showing good cultural depth); mussel also present, land snail density heavy.

\section{MC 247 (UTSA 32)}

Location: Site exists along northern side of slough, primary to the Frio River $300 \mathrm{~m}$ south; site runs along the slough bank slope at least $400 \mathrm{~m}$.

Area: $30,000 \mathrm{~m}^{2}$

Elevation: $230-245^{\prime}$

Environment: Cultivated alluvium/loam; brush.

Evidence: Large, moderate flake scatter shows in cultivated field and gullies eroding through brush into slough bottom, 3 dart points (a possible Frio, a possible Uualde or Fairland type, another unidentified edgeserrated), a possible Guadalupe tool, a unifacial "gouge," \pm 10 cores, 4 thin bifaces, 6 thick bifaces, a few pieces of ground sandstone, other sandstone, smal1 amounts of burned chert. Very slight amount of historic debris in cultivated field along upper northern site limits.

41 MC 248 (UTSA 33)

Location: Low terrace east of Cottonwood Creek, just upstream of a fork; this is a primary stream to the Frio River $300 \mathrm{~m}$ south.

Area: $6000 \mathrm{~m}^{2}$

Elevation: $220^{\prime}$ 

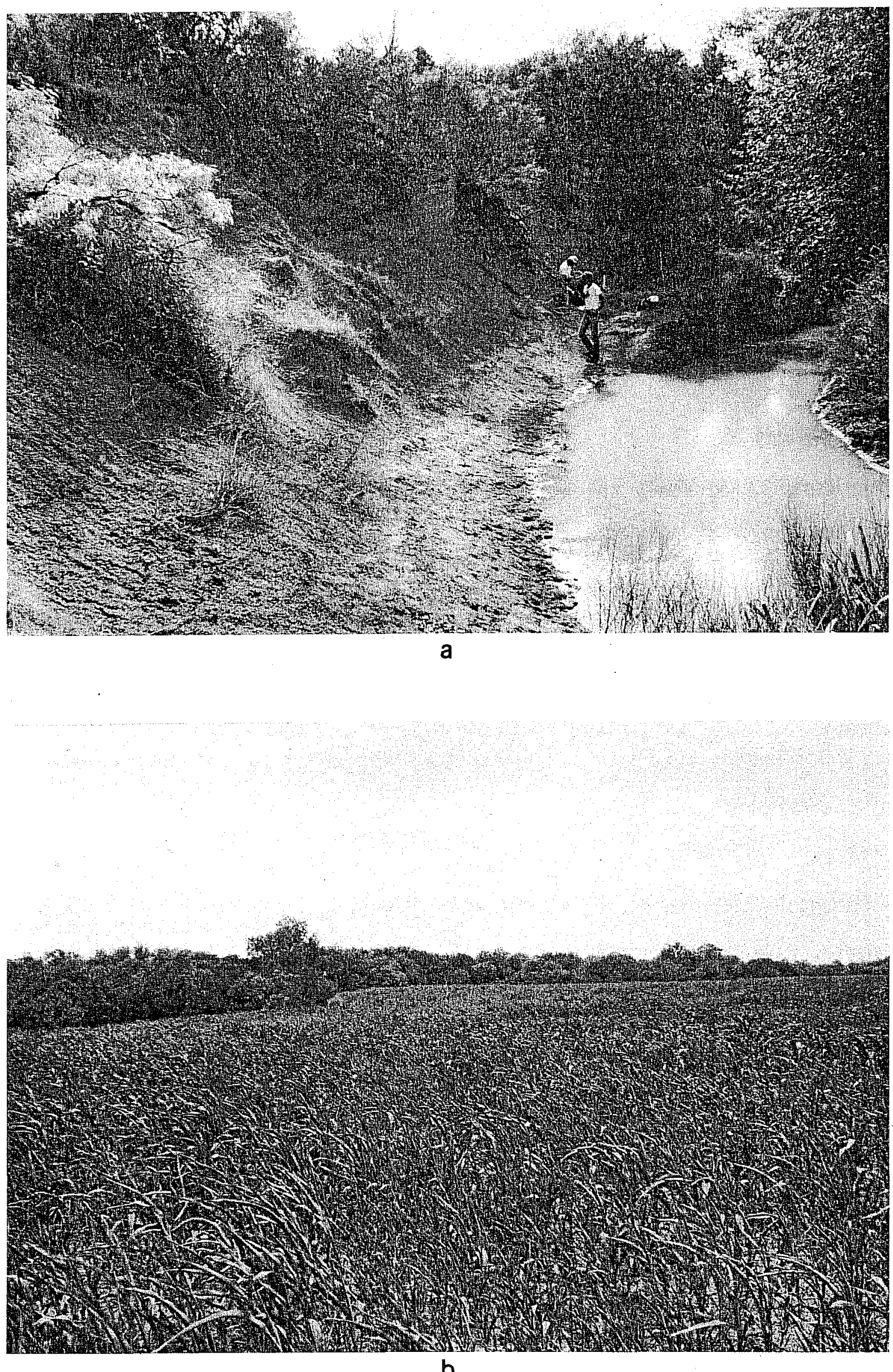

Figure 11. Study Area 8. a, view along tributary of Frio River at 41 MC 246; b, view northeast of 41 MC 257 at the Frio River. 
Environment: Brush, grasses; alluvium/loam.

Evidence: Light flake scatter, 3 dart points (possible Fairland), 2 thin bifaces, several cores, possible chert ground stone, scattered mussel fragments, a few pieces of burned chert. Modern garbage dump nearby.

41 MC 249 (UTSA 34)

Location: Site is just north of a major slough on beginning valley slope; Frio River is $400 \mathrm{~m}$ south.

Area: $40,000 \mathrm{~m}^{2}$

Elevation: $230-240^{\prime}$

Environment: Brush, grasses, cactus; alluvium/loam.

Evidence: Light flake scatter (palmwood-petrified wood in debitage) seen over a large area; dart point fragment, 4 thick bifaces, possible Guadalupe tool bit fragment, 2-3 cores, land snai1, trace of burned chert.

\section{MC 250 (UTSA 35)}

Location: Site is just north of major slough at beginning valley: slope; Frio River $300 \mathrm{~m}$ south.

Area: $22,000 \mathrm{~m}^{2}$

Elevation: $232-240^{\prime}$

Environment: Coastal Bermuda pasture grass, brush, bare corral ground, a) 1 uvium/loam.

Evidence: Light flake scatter mostly seen in the corral area; Ensor or Ensor-Frio point, possible Marshall point, smal1 Catan-like biface, plus 2 other unidentified dart points; a thin triangular biface fragment, a thick quartz biface, several cores, mussel fragments, a little burned chert, a few sandstone fragments, and petrified wood in smal1 amounts.

41 MC 251 (UTSA 36)

Location: Site is just north of primary drainage (Salt Branch); Frio River is $250 \mathrm{~m}$ southeast; beginning valley slope.

Area: $\quad 15,000 \mathrm{~m}^{2}$

Elevation: $232-250^{\prime}$

Environment: Brush with much bare ground. 
Evidence: Light to moderate flake scatter with thin bifaces, fewer thick bifaces, cores, land snail, abundant burned rock; "⿱艹⿰氵㔾夂ssel present in sma11, dense concentrations. A hearth revealed in a gully at $50-\mathrm{cm}$ depth. Low density evidence surrounds site uphi11 and toward 41 MC 247 to the east.

41 MC 252 (UTSA 37)

Location: Floodplain terrace edge just north over the Frio River; on top and in slope gullies.

Area: $2250 \mathrm{~m}^{2}$

Elevation: $230^{\prime}$

Environment: Riparian hardwoods, etc., brush, grasses; sand/alluvium, heavy gravel, sandstone outcrops.

Evidence: Light flake scatter, 5 cores, a unifacial tool, a retouched flake, mussel and land snail present; a low density scatter of evidence is in area, especially on gravel-dominant uplands south.

Comment: Minima1.

41 MC 253 (UTSA 38)

Location: Site is located on a narrow floodplain area below an abrupt bluff on the south side of the Frio River.

Area: $4900 \mathrm{~m}^{2}$

Elevation: $230^{\prime}$

Environment: Brush, riparian hardwoods; alluvium/clay with.gravel and sandstone outcroppings.

Evidence: Minimal site evidence consisted of a light flake scatter, 5 cores, a unifacial tool, and a retouched flake. Mussel and land snail were present.

Comment: These materials are possibly derived from erosional action along a drainage flowing northward throughout the locality.

41 MC 254 (UTSA 39)

Location: Site is in lower area of drainage (valley wa11) flowing from gravel ridges north into the Frio River $150 \mathrm{~m}$ away.

Area: $9375 \mathrm{~m}^{2}$ 
Elevation: $230-250^{\prime}$

Environment: Brush, sparse grasses, bare areas; alluvium/clay.

Evidence: Moderate flake scatter over a large area; $4-5$ thin bifaces, \pm 4 thick bifaces, cores, smal1 amount of burned chert, land snail present, mussel fragments plentiful in certain areas.

41 MC 255 (UTSA 40)

Location: Site is on terrace just over the Frio River running northeast by it (floodplain).

Area: $4000 \mathrm{~m}^{2}$

Elevation: $230-238^{\prime}$

Environment: Hardwoods, etc., on Frio River, brush, cultivated, grass; a) 1 uvium.

Evidence: Light flake scatter, 6 thin bifaces including a probable dart point, several thick bifaces, 3 cores, 3 pieces ground sandstone ( 2 pieces fit together; the third with abraded grooves), small amount of burned rock, mussel.

41 MC 256 (UTSA 41) (see Site Descriptions: Historic)

41 MC 257 (UTSA 42)

Location: Floodplain terrace immediately south of Frio River (Fig. $11, \mathrm{~b})$.

Area: $8750 \mathrm{~m}^{2}$

Elevation: $230-232 '$

Environment: Riparian hardwoods, brush, cultivated field; alluvium.

Evidence: Light flake scatter, with areas of plentiful musse1, 2-3 cores, a dart point fragment with slight side notches, a dart point (or other to01) with thinned base and beveled edges, a thick biface, trace of 7 and snails.

41 MC 258 (UTSA 43)

Location: Low rise just off Hackberry Creek drainage, where it splits into a slough-like southern loop of the Frio River (probable meander). 
Area: $900 \mathrm{~m}^{2}$

Elevation: $234-239^{\prime}$

Environment: Brush, grasses, a11uvium/10am.

Evidence: Light scatter of flakes and mussel, a thin biface distal fragment, a unifacial dart point, 2-3 cores, a split cobble with. "bit" worked on one edge, sandstone present, some burned chert and sandstone, a double-faceted ground sandstone, land snails.

Comment: This site is opposite 41 MC 259.

41 MC 259 (UTSA 44)

Location: Low rise just east of Hackberry Creek's junction at a sloughmeander which loops to the Frio River about $600 \mathrm{~m}$ northwest.

Area: $7500 \mathrm{~m}^{2}$

Elevation: $234-239^{\prime}$

Environment: Brush on creek edge, cleared field of grass and weeds.

Evidence: Light flake scatter, small triangular biface (Catan ?), a Frio point, 3 other thin bifaces, 2 thick bifaces including one with cortex (possibly a "gouge"), a core, land snail, and sandstone present.

41 MC 260 (UTSA 45), Areas $A$ and $B$

Location: Site is on either side of a slough-meander which runs as a southern 100p of the Frio River $600 \mathrm{~m}$ northwest; floodplain.

Area: $12,500 \mathrm{~m}^{2}$

Elevation: $230-237^{\prime}$

Environment: Brush, grasses and other thick drainage vegetation, cultivated (cane) field.

Evidence: Heavy scatter of burned sandstone, flakes, mussel, land snail and tools; 7 or more various thin bifaces (includes a possible arrow point preform), 3 unifaces (triangular, bit edged), another uniface with utilized edge, 2-3 dart points (one stemmed, one triangular), 3-4 thick bifaces, \pm 12 cores, $4-6$ ground sandstone fragments, 5 potsherds, and a bead made of mussel shell.

Comment: In areas, burned sandstone was in large concentrations; soil also appeared with possible charcoal staining; some bone fragments noted. 
41 MC 261 (UTSA 46)

Location: Terrace slope just north of Salt Branch drainage.

Area: $7500 \mathrm{~m}^{2}$

Elevation: $228-235^{\prime}$

Environment: Brush, sparse grass, bare ground; alluvium/loam.

Evidence: Light flake scatter, 2-3 cores, thick biface, 3 thin bifaces

( 1 is Catan-1ike), burned chert, some scattered sandstone; 4-5 sandstone hearths seen eroding from road and gul1y at less than 50-cm depth.

41 MC 262 (UTSA 47)

Location: Terrace slope just north of Frio River.

Area: $21,000, \mathrm{~m}^{2}$

Elevation: $212^{\prime}$

Environment: Brush, grasses, riparian growth nearby; alluvium/10am.

Evidence: Moderate flake scatter with abundant mussei, 12 cores, a biface fragment plus another thick biface, much burned material, land snail, and sandstone present, 2 burned rock concentrations.

Comment: A low density scatter (possibiy part of the site) runs west from site, along the river.

41 MC 263 (UTSA 48)

Location: Terrace slope about $100 \mathrm{~m}$ north of Frio River near the confluence of the San Miguel Creek.

Area: $9800 \mathrm{~m}^{2}$

Elevation: $212^{\prime}$

Environment: Brush, grasses, riverine vegetation nearby; al Tuvium/clay.

Evidence: Light to moderate flake scatter seen about a prominent gul7y system; a thin biface, 2 thick bifaces; \pm 6 . cores, a sma 11 amount of burned chert, a flake blade and an unidentified dart point. 
41 MC 264 (UTSA 49) prehistoric component

Location: Terrace slope (floodplain) less than $100 \mathrm{~m}$ north of the confluence of the Frio River and San Miguel Creek.

Area: $1000 \mathrm{~m}^{2}$ (approx.)

Elevation: 214'

Environment: Brush, grasses, riverine vegetation; alluvial soil.

Evidence: About $8 \mathrm{~m}$ south of historic sandstone foundations, a Scallorn arrow point was located in a gully; other nearby material: flakes, core, and a few mussels.

\section{MC 265 (UTSA 50)}

Location: Terrace slope (floodplain) less than $200 \mathrm{~m}$ north of the Frio River; San Miguel confluence nearby; site is also above a small drainage, but revealed mainiy by a sendero cut.

Area: $4500 \mathrm{~m}^{2}$

Elevation: $216^{\prime}$

Environment: Brush, cactus, and grass; graded road; alluvium/loam.

Evidence: Moderate flake scatter with several thick and thin bifaces, \pm 6 cores, plentiful musse1, land snail, some burned chert, possible ground sandstone fragment reported by landowner.

\section{MC 266 (UTSA 51)}

Location: On prominent bluff of floodplain terrace edge $50 \mathrm{~m}$ north of slough drainage running from Frio River, $180 \mathrm{~m}$ southwest; San Miguel creek confluence nearby.

Area: $6250 \mathrm{~m}^{2}$

Elevation: $212-218^{\prime}$

Environment: Brush, cactus, grasses; al1uvium/10am.

Evidence: Heavy scatter of burned chert, burned sandstone and flakes; also abundant mussels, land snail present, side-notched dart point fragment of petrified wood, another triangular biface fragment (possibly Tortugas), 3 other thin biface fragments, 2 thick biface fragments; landowner reported that relic collecting was frequent (pottery reported from site). 
41 MC 267 (UTSA 52)

Location: Slope of floodplain terrace about $75 \mathrm{~m}$ north of Frio River; San Miguel Creek confluence $2.24 \mathrm{~km}$ northeast.

Area: $\quad 25,000 \mathrm{~m}^{2}$

Elevation: $210-220^{\prime}$

Environment: Brush, cactus, riparian vegetation and cleared field nearby; alluvium/loam, light gravel outcrops nearby.

Evidence: Light flake scatter with one area heavy in burned chert; low density flake scatters east, north, and west of site; a biface fragment, a utilized flake, one chert hearth; area has been heavily collected according to the landowners.

41 MC 268 (UTSA 53)

Location: Floodplain; west side of slough running north-south; another slough connecting the San Miguel Creek to the Frio River runs west of site; San Miguel Creek is $200 \mathrm{~m}$ north, Frio River $400 \mathrm{~m}$ south, their confluence to the east (Fig. 12,a).

Area: $30,000 \mathrm{~m}^{2}$

Elevation: $220^{\prime}$

Environment: Cleared field in sparse, short grass; brush, slough vegetation nearby; al1 uvium/loam.

Evidence: Moderate scatter of flakes, heavier in places; some burned chert, trace of musse1, no land snai1, 2 side-notched dart points (one Ensor), Scallorn arrow point, a potsherd, 6 fragments of ground sandstone, \pm 10 cores, a thick biface distal fragment, and a utilized flake (Fig. 13).

41 MC 269 (UTSA 54)

Location: Floodplain terrace $120 \mathrm{~m}$ south of San Miguel Creek; Frio River confluence is $2.4 \mathrm{~km}$ east.

Area: $600 \mathrm{~m}^{2}$

Elevation: $220^{\prime}$

Environment: Brush, cactus, grasses, riparian vegetation nearby; a Tluvial soil. 


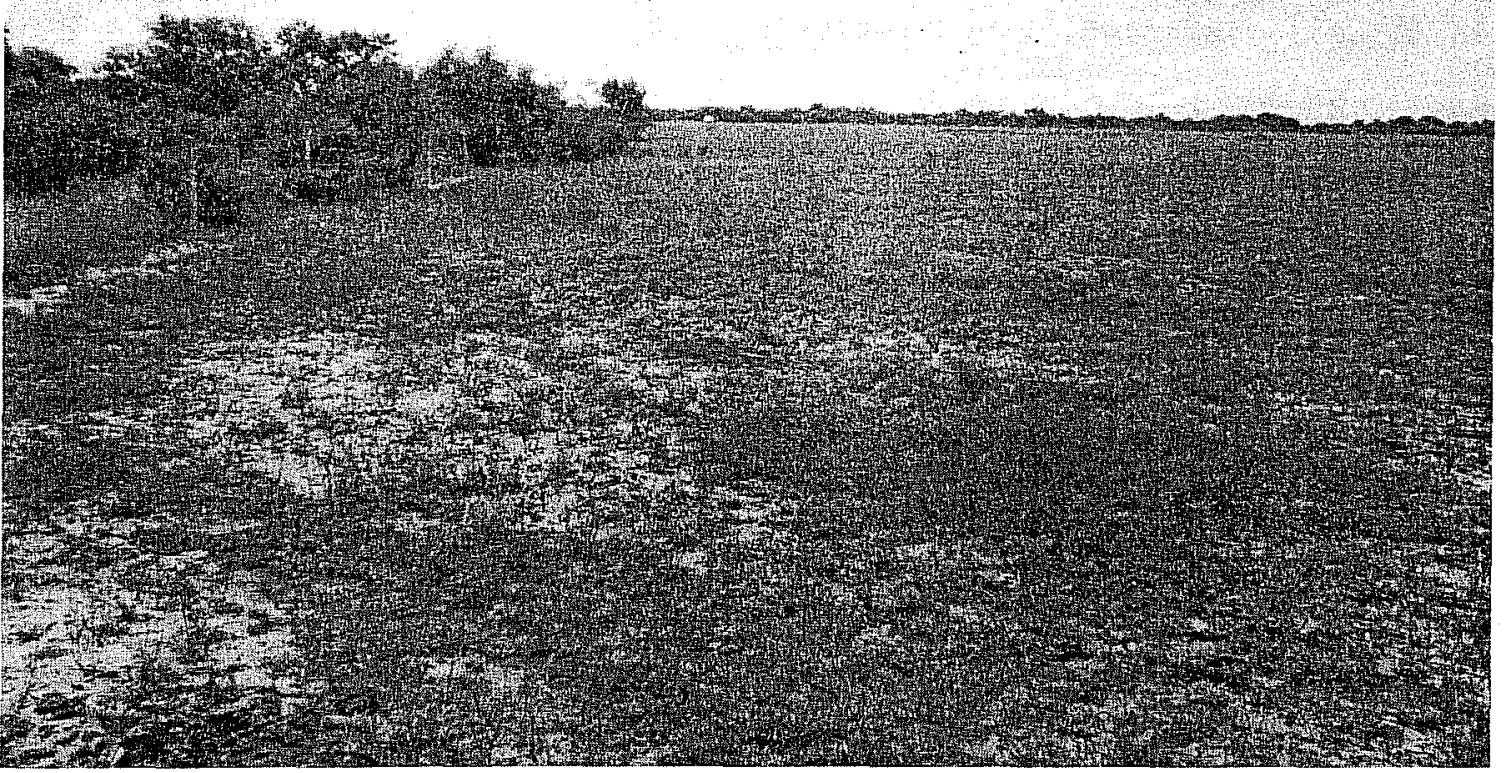

a

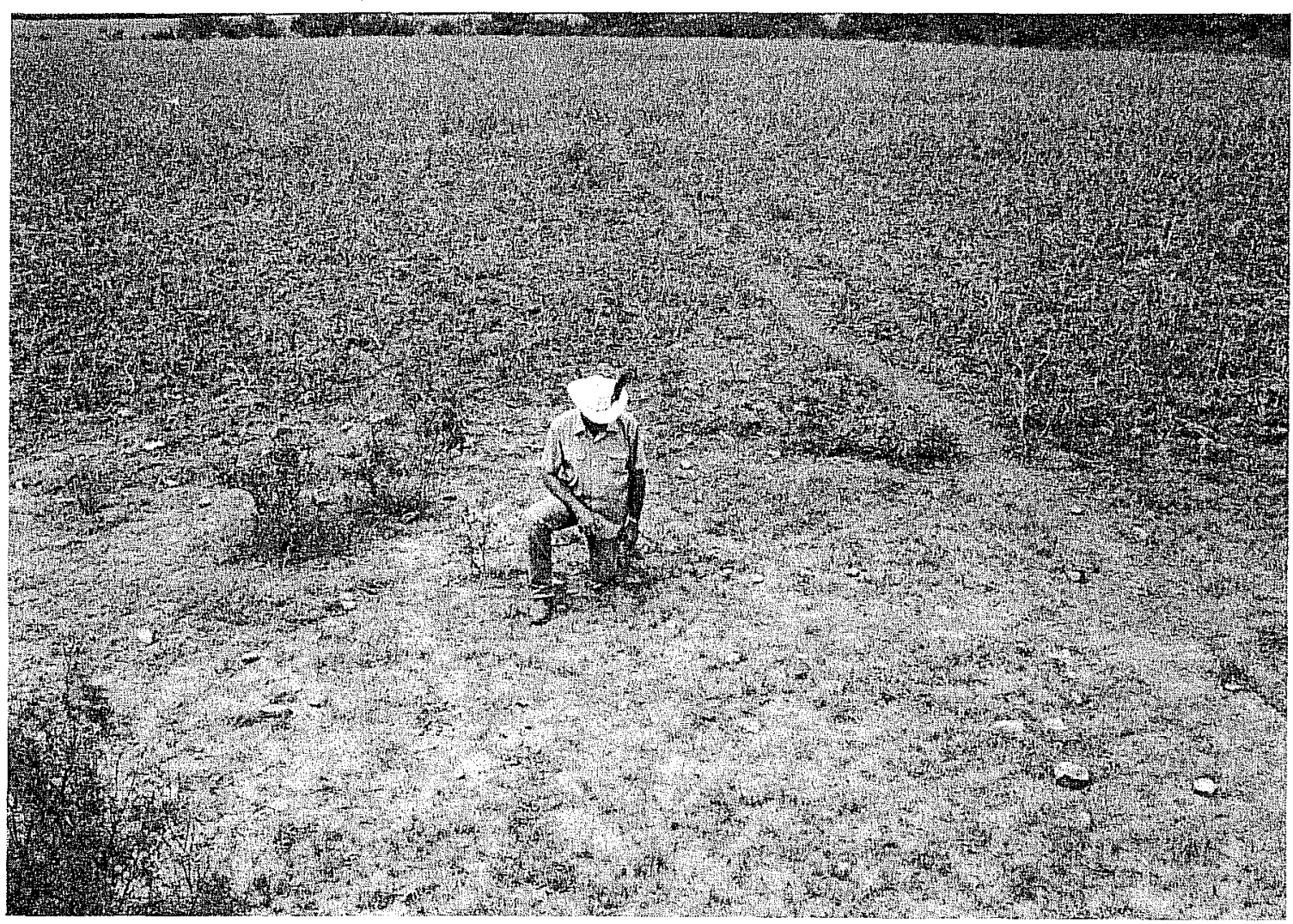

b

Figure 12. Study Area 7. a, view south of 41 MC 268, slough to left; b, view looking south at 41 MC 293, note historic sandstone remnants. 

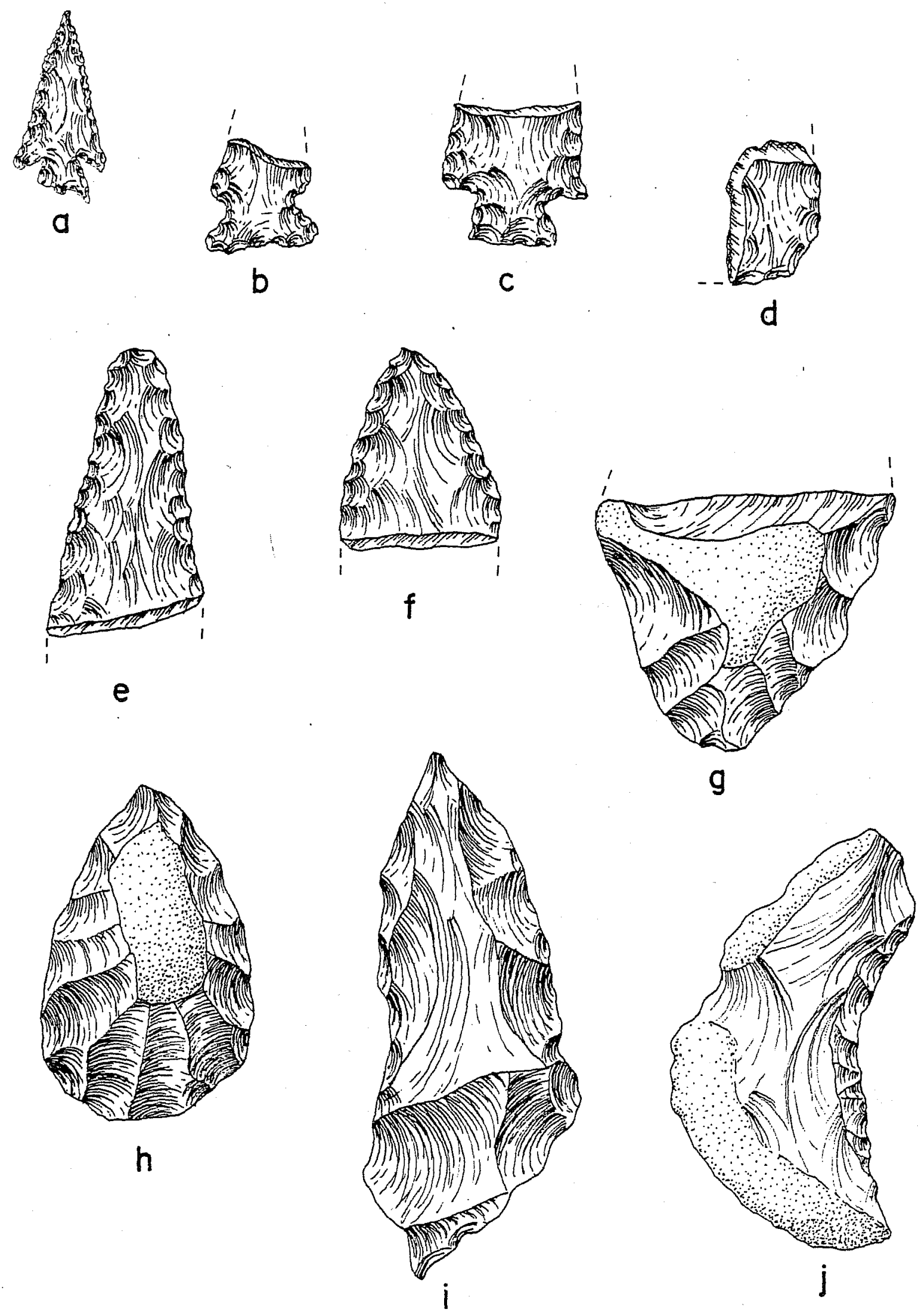

Figure 13. Examples of Field-Sketched Artifacts. All specimens illustrated are from site 41 MC 268 (UTSA 53). I1lustrated actual size. 
Evidence: Light flake scatter seen mainly in backdirt from recent stock tank (?) construction; also about 5 cores, 2 thin biface fragments, a possibie ground piece of sandstone, plus other sandstone, a few burned chert fragments, mussel shel1 present.

41 MC 270 (UTSA 55)

Location: River terrace floodplain, with Frio River running north (along western side of site) $120 \mathrm{~m}$ away.

Area: $30,000 \mathrm{~m}^{2}$

Elevation: $200-210^{\prime}$

Environment: Coastal Bermuda grass, brush, riverine vegetation nearby; alluvium; sandstone outcrops on valley wall $300 \mathrm{~m}$ southeast.

Evidence: Light flake-mussel scatter covered a large area; 3 thick bifaces, 15 cores, some burned chert, possibly ground sandstone, other sandstone present, land snail.

41 MC 271 (UTSA 56)

Location: Steep valley wa11, southwest of Frio River ( $350 \mathrm{~m}$ north) on east side of sma 11 drainage.

Area: $7500 \mathrm{~m}^{2}$

Elevation: $240-250^{\prime}$

Environment: Brush, grasses, cactus, alluvial soil; heavy sandstone outcrops.

Evidence: Light flake scatter in an area of continued low density debris; 3 thick bifaces, 4 thin bifaces (one possible Tortugas); \pm 6 cores.

Comment: Five bifaces were in $10 \times 10 \mathrm{~m}$ area, but this was sti11 considered a minimal site with vague boundaries.

41 MC 272 (UTSA 57)

Location: Near the top of an upland ridge; more exposed to the valley wall overlooking the Frio River about 350 m west.

Area: $25,000 \mathrm{~m}^{2}$

Elevation: $245-274^{\prime}$ 
Environment: Brush, long grasses; alluvial soil, some gravel; heavy sandstone outcrops nearby downslope, west and north.

Evidence: Light flake scatter, a few pieces of burned chert, a few cores.

Comment: Minimal evidence; low density flake scatters are in surrounding area.

41 MC 273 (UTSA 69)

Location: Modern floodplain; lower terrace on north side of San Miguel Creek.

Area: $\quad 100,000 \mathrm{~m}^{2}$

Elevation: $225-240^{\prime}$

Environment: "Thorn brush; cleared pasture; alluvium/sand with some gravel; sand.

Evidence: Moderate scatter of flakes, cores, mussel, snails, bifaces, and fragments, including possible Tortugas and Bulverde dart points; burned chert and petrified wood present.

Comment: Heavy relic collecting.

41 MC 274 (UTSA 70)

Location: Floodplain of minor drainage running into San Miguel Creek.

Area: $35,000 \mathrm{~m}^{2}$

Elevation: 228-238'

Environment: Cleared pasture with some light brush; gravel uplands nearby; alluvium/loam soil.

Evidence: Light scatter of flakes, cores, bifaces and fragments, and ground sandstone; some areas of much burned chert; 27so, a leaf-shaped dart point and a unifacial "gouge."

41 MC 275 (UTSA 71)

Location: Floodplain north of San Miguel Creek; slough-meander also runs between the site and San Miguei creek.

Area: $125,000 \mathrm{~m}^{2}$ 
Elevation: $220-226^{\prime}$

Environment: Brush, slough vegetation nearby; alluvium/clay with gravel especially on neighboring valley wal1; also gypsum, petrified wood, and sandstone.

Evidence: Heavy to moderate scatter of flakes, cores, bifaces, burned chert, and sandstone; also pottery and an Ensor dart point of chalcedony.

Comment: Also heavily relic collected, this site has most material in its eastern area, the probable area of most occupation; quarry activities seem represented in the western component.

41 MC 276 (UTSA 72)

Location: Floodplain of upper reaches of Elm Creek, immediately east of site; the Frio River is $4.0 \mathrm{~km}$ southeast.

Area: $7500 \mathrm{~m}^{2}$

Elevation: $228^{\prime}$

Environment: Cleared pasture with a few retama, prickly pears; mesquite and hardwoods on drainage bottom; alluvium/loam with little gravel.

Evidence: Two areas of materia1: Area $A$ is on the floodplain where exposed surface shows a moderate scatter of flakes, burned chert and bifaces including 3 possible Tortugas, 1 stemmed dart point and another triangular round base form. In Area B much evidence was seen in the eroding creek bank about $50 \mathrm{~m}$ north; this consists of burned chert, sandstone including an abrader tool, flakes, another possible Tortugas biface, mussels including a perforated specimen; also, definite bone preservation shown by a deer phalange about $30 \mathrm{~cm}$ below surface; total depth could be $50+\mathrm{cm}$.

41 MC 277 (UTSA 73)

Location: Lower valley wall west of upper branch of Elm Creek; Frio River $4.0 \mathrm{~km}$ south.

Area: $16,000 \mathrm{~m}^{2}$

Elevation: $230-236^{\prime}$

Environment: Moderate brush; al7uvium/loam; gravel uplands nearby.

Evidence: Most material appears just below surface, often thrown out of animal holes; material consists of flakes, some burned chert and sandstone, 3 thick and 2 thin bifaces, 4 cores, mussel, and snails. 
41 MC 278 (UTSA 74)

Location: Floodplain-valley wall just east of upper branch of Elm Creek; Frio River $4.0 \mathrm{~km}$ south (Fig. 14,a,b).

Area: $15,000 \mathrm{~m}^{2}$

Elevation: $226-238^{\prime}$

Environment: Cleared pasture, with mesquite, hardwoods, other drainage vegetation on lower side, and upland thorn brush to the east; alluvium/loam with nearby gravels.

Evidence: Evidence shows where creek erosion acts on the lower slope and animal disturbance reveals buried material upland; coastal Bermuda grass conceals the area in between; moderate scatters are seen, including flakes, mussel, snails, burned chert, bifaces, and a metate sandstone fragment.

41 MC 279 (UTSA 75)

Location: Floodplain on western side of upper branch of Elm Creek; Frio River $4.0 \mathrm{~km}$ south.

Area: $1750 \mathrm{~m}^{2}$

Elevation: $230^{\prime}$

Environment: Cleared pasture, with hardwoods, mesquite, and drainage vegetation nearby; large recent tank dam $150 \mathrm{~m}$ north; alluvium/loam.

Evidence: : Light scatter of flakes, burned chert, and 3 biface fragments seen in smal1 area of bare ground.

Comment: Minimal site; other low density flake scatters noted in immediate area.

47 MC 280 (UTSA 76 )

Location: Valley wall ridge running north to south, just north of upper Elm Creek; Frio River $2.4 \mathrm{~km}$ southeast.

Area: $100,000 \mathrm{~m}^{2}$

Elevation: $220-236^{\prime}$

Environment: Brush vegetation with vehicle-eroded areas and sparse grasses. Alluvial soil with some gravel and sandstone. 


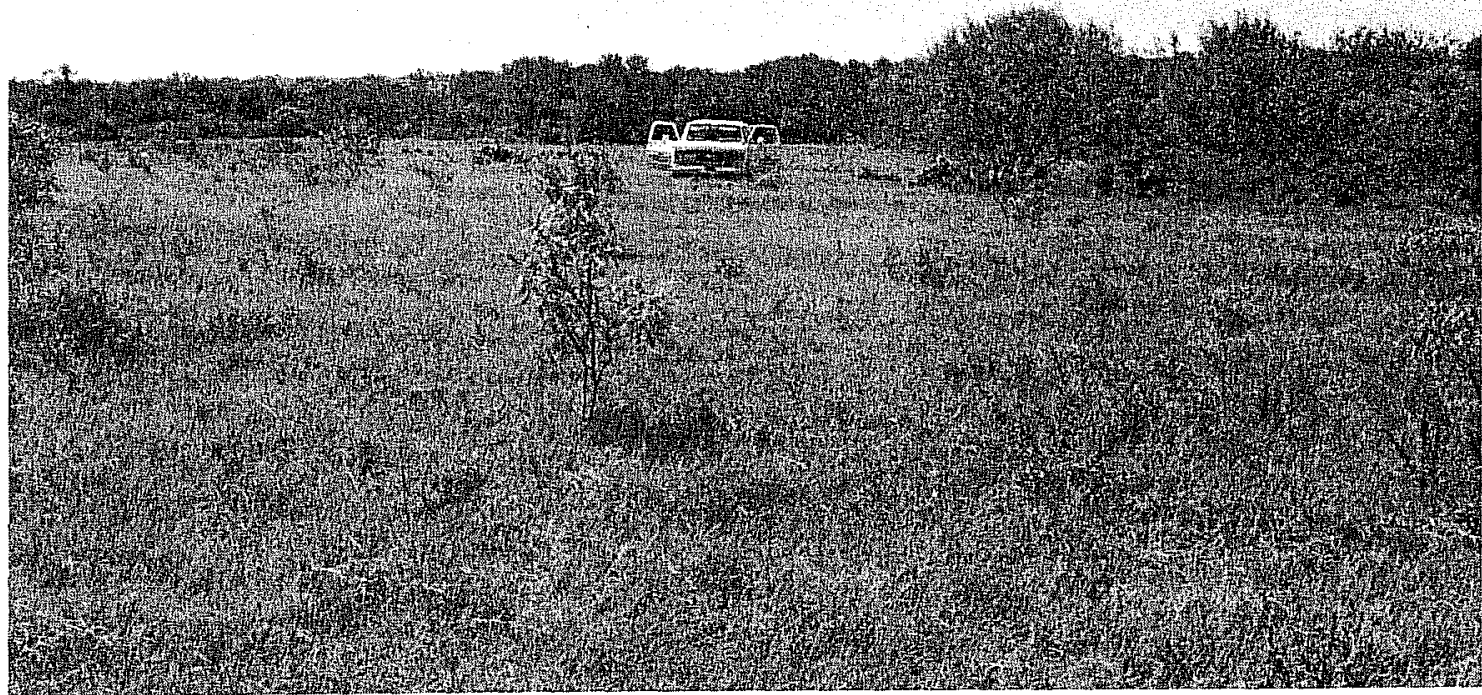

a

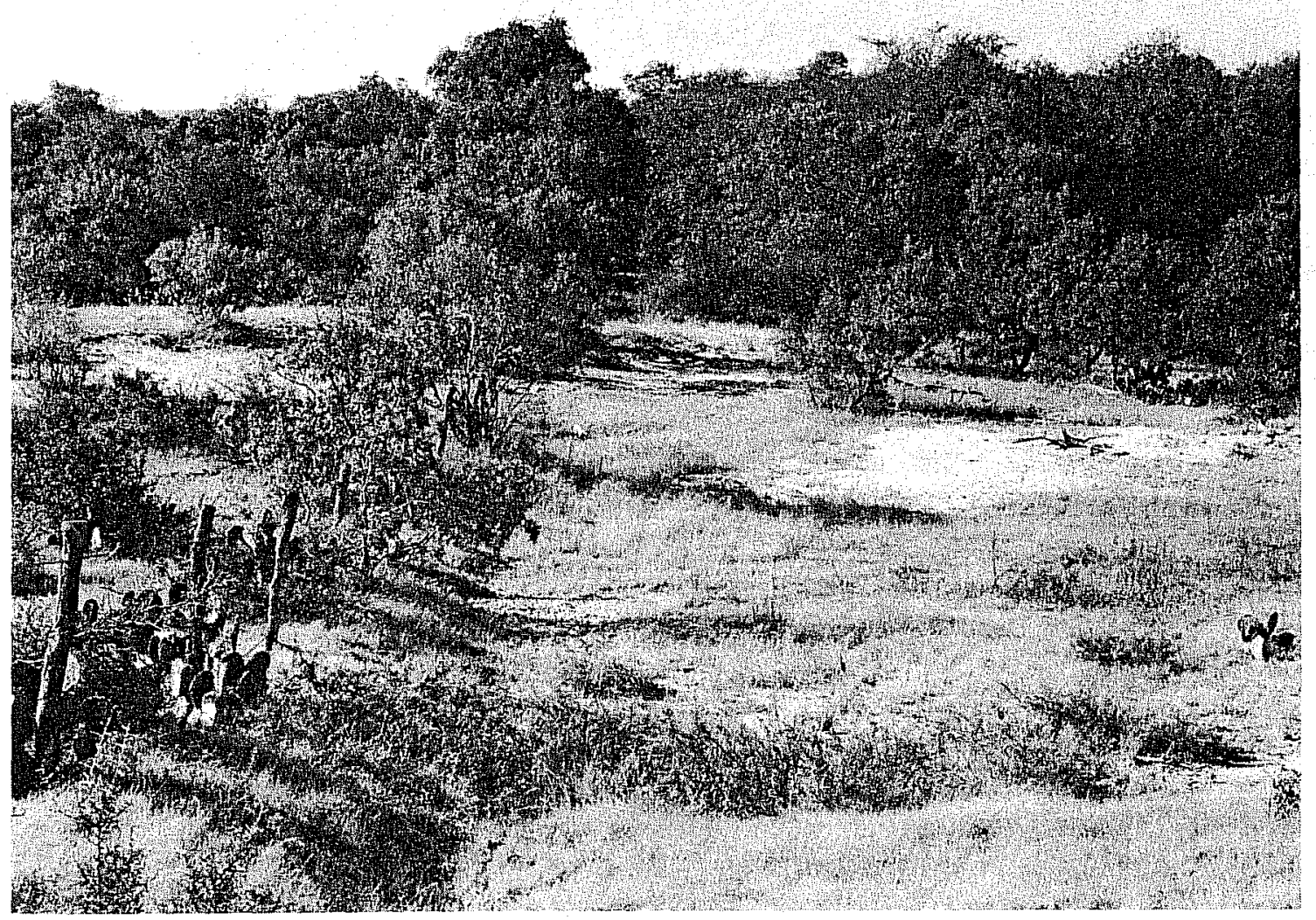

b

Figure 14. Study Areas 6 and 7. a, study Area 6 (view south of 41 MC 278; Elm Creek to the right); b, Study Area 7 (view south of 41 MC 278, Area B). 
Evidence: Site consists of an extensive scatter of flakes, burned chert, burned sandstone, mussel fragments, and land snail. At least 2 sandstone hearths were identified, one of which had several scallorn arrow points in proximity. Cores, more than 11 bifaces, a serrated arrow point and a possible arrow point preform were also found.

41 MC 285 (UTSA 81)

Location: Valley wal1, $200 \mathrm{~m}$ south of Frio River.

Area: $22,500 \mathrm{~m}^{2}$

Elevation: $210-220^{\prime}$

Environment: Moderate brush, grasses; alluvium/clay, gravel outcrop on western area, sandstone uphi11.

Evidence: Site consists of a light to moderate scatter of flakes, cores, and bifaces ( 3 thick, 1 thin); gully erosion in the western site area exhibits 3-4 sandstone hearths; a crude Langtry-like dart point and a palmwood "gouge"-like tool also was in this area.

41 MC 286 (UTSA 82)

Location: Floodplain terrace rise immediately south of the Frio River; a primary creek confluence is just west of this.

Area: $16,875 \mathrm{~m}^{2}$

Elevation: $200-210^{\prime}$

Environment: Light brush cover and grasses; riverine hardwoods nearby; a 17 uvial soil, natural gravel, and sandstone in vicinity.

Evidence: Light to moderate flake scatter including cores, burned chert, 3 thick and 3 thin bifaces, 2 possible triangular Tortugas points, a Perdiz arrow point, and a possible arrow point preform, a ground stone metate fragment, and a potsherd.

Comment: This site is located by a historic river-crossing area on the Edna Henry property.

\section{MC 294 (UTSA 90)}

Location: Floodplain terrace edge, with lowest floodplain, slough, and Frio River immediately north. A primary drainage also enters the Frio River east of site and branches back west to accentuate a subtle rise (Area A), running east-west along the terrace. 
Area: $90,000 \mathrm{~m}^{2}$

Elevation: 220'

Environment: Cultivated field, riverine vegetation nearby; Frio River loops directly north of site, thus providing close proximity plus extensive active floodplain; alluvial soil.

Evidence: This site consists of an extensive prehistoric scatter running along this length of the Frio River where the cultivated field meets the brush. Two Areas, $A$ and $B$, are respectively noted in the east and west. The former displays light to moderate density of flakes, land snails, musse], and Late Prehistoric indicators: end scrapers, Perdiz arrow point, pottery; also found: Ensor dart point, ground sandstone, and possible remnant concentrations of mussel and burned sandstone; Area $B$ continues west after a slight topographic break and artifacts decrease; here more flakes, bifaces, and a possible Guadalupe tool were found.

Comment: Area $B$ seems to run into the vague boundaries of prehistoric scatter at 41 MC 18.

\section{MC 296 (UTSA 92)}

Location: Floodplain on south side of Elm Creek, where a distinct drainage curve widens to exhibit slough characteristics and steeper banks below the site; Frio River is about $1.92 \mathrm{~km}$ south-southeast.

Area: $10,000 \mathrm{~m}^{2}$

Elevation: $210^{\prime}$

Environment: Moderate to thick brush and hardwoods along creek; thinner brush and more grass away from creek; alluvial soil.

Evidence: A moderate scatter of flakes, some burned chert, musse1, and tools exist along this bend; sandstone metate; bone preservation revealed in animal backdirt (such preservation in area usually indicates Late Prehistoric occupation).

\section{MC 297 (UTSA 93)}

Location: Floodplain just south of Elm Creek; Frio River over $1.6 \mathrm{~km}$ south-southeast; no outstanding topographical situation.

Area: $10,000 \mathrm{~m}^{2}$

Elevation: $214^{\prime}$

Environment: Moderate brush, grasses; al7uvial soil. 
Evidence: Site consists of a light scatter of flakes, \pm 6 cores, 4 thin bifaces including a Perdiz dart point and another possible dart point, a crude biface, and a triangular "scraper"; also a palmwood test cobble.

Comment: This site may continue west onto the Mosier property, which was unavailable in August 1979.

41 MC 298 (UTSA 94)

Location: Floodplain, just west of Elm Creek before it joins the Frio River; the southward-flowing creek loops east, south, and west as it enters the river, forming a peninsular rise where the site is located.

Area: $8200 \mathrm{~m}^{2}$

Elevation: $200-210^{\prime}$

Environment: Light brush, grasses, some hardwoods; alluvial soil.

Evidence: Two areas of exposed material are seen on the northern and southern gutlies of the floodplain terrace (peninsula) banks, Areas A and $B$ respectively; very little is seen on the surface joining the two areas, although a few flakes and a prehistoric potsherd were found; most material is below surface and seen at depths $30-100 \mathrm{~cm}$ below surface; besides flakes, other materials noted were burned chert, snails, mussels, a triangular biface fragment, a Scallon arrow point fragment, and cores.

\section{Site Descriptions: Historic*}

41 MC 229 (UTSA 10)

Location: Rather flat area north of major valley wa11; Frio River is about $4.0 \mathrm{~km}$ north.

Area: $10,000 \mathrm{~m}^{2}$

Elevation: $220^{\prime}$

Environment: Cultivated fields, brush, grass; alluvium/loam.

Evidence: House structure (wrecked), cisterns, shed, outhouse, corral, and grain storage building. Recently demolished, much debris remains: metal, ceramics, glass, bricks, and old mule-farming equipment. The main house was wood frame, set on posts. Dump area northwest of site, toward 41 MC 230, is a similar farm site.

Comment: Occupation goes back from recent times possibly into the 1920 s or earlier (Zieschang property). 
41 MC 230 (UTSA 12)

Location: Rather flat area, north of major valley wall; Frio River to the north, several miles away.

Area: $10,000 \mathrm{~m}^{2}$

Elevation: $215^{\prime}$

Environment: Cultivated fields, grass and brush southeast; alluvium/loam.

Evidence: A11 buildings standing; recent abandonment by farmer for storage and migrant workers camp; main house is wood frame with tin roof, brick chimney; wooden sheds and a large barn are nearby; dump located southsoutheast about $200 \mathrm{~m}$ toward 41 MC 229 (similar historic site, but razed).

Comment: Last owner was E. W. Muecke.

\section{MC 237 (UTSA 22)}

Location: Up slope (valley wall) from Salt Creek drainage to the east.

Area: $400 \mathrm{~m}^{2}$

Elevation: 220 '

Environment: Mesquite, cactus, grasses; alluvial soil.

Evidence: Site consists of a smal1 area with about 30 bricks or brick fragments surrounding a consolidated black "slag" base. This rectangle is $58 \mathrm{~cm}$ north-south, $120 \mathrm{~cm}$ east-west, and $4-5 \mathrm{~cm}$ thick. It has a charcoal-burned appearance, but most of it is hard, solid, with some air bubbles. It may be some kind of kiln or forge. Some bricks state: "Acme," "Standard," ". . Malakof, Tx." Also present: bottle neck, metal fragment with "A7Tison's Best" printed on it, and Tight prehistoric debris. A low density historic scatter is located ca. $350 \mathrm{~m}$ west.

41 MC 240 (UTSA 25)

Location: Northwest of primary drainage to the Frio River, $1.28 \mathrm{~km}$ to the east; site is in bare, eroding gully.

Area: $625 \mathrm{~m}^{2}$

Elevation: 206'

Environment: Brush, cactus, grasses; alluvial/loam.

Evidence: This is an old oil we11 pipe which is reputed to be one of the first wells dug in the region; the historic marker in Calliham 
refers to it. The pipe is 5-6 inches in diameter, with a concrete-filled sleeve cap; some historic and prehistoric debris is in the area; clear glass fragments (window pane ?), thick red glass, white paste, earthenware, blue-gray square base bottle, some metal fragments, chert flakes, and a core.

41 MC 245 (UTSA 30) historic component

Location: Floodplain terrace over slough-like primary drainage to the Frio River (600 m east).

Area: $1000 \mathrm{~m}^{2}$

Elevation: $200^{\prime}$

Environment: Brush, grasses, cultivated field to south; alluvium/loam.

Evidence: This is a wood frame building about $5 \mathrm{~m}^{2}$; and it is on the verge of collapse. Some historic debris scatters east toward the river: glass fragments, earthenware, metal latch fragment, and a thick crockery sherd that is black-brown on one side, white glaze on the other. If used for a residence, it was a very sma11, simple one; wood weathering alone appears to be about 50 years old. A cultivated field, which includes prehistoric evidence, currently borders this site.

41 MC 256 (UTSA 41)

Location: Floodplain terrace just south of the Frio River.

Area: $900 \mathrm{~m}^{2}$

Elevation: $230-238^{\prime}$

Environment: Brush, cultivated grass field, riparian vegetation nearby; alluvial soil.

Evidence: Historic dump located within prehistoric site 41 MC 256; a $10 \mathrm{~m}^{2}$ area shows a concentration of all colors of glass, bottle, and window pane fragments, stoneware, earthenware, 1930 s decal ware, porcelain stamped "made in Germany," cup handle with blue-green design, etc., buttons, nails, ammunition shells, metal. Some prehistoric material is intermixed. The Jane Horton home is nearby and is probably related; most material dates from 1920s-30s.

41 MC 264 (UTSA 49)

Location: Terrace slope (floodplain) less than $100 \mathrm{~m}$ north of Frio River; San Miguel Creek confluence nearby. 
Area: $2400 \mathrm{~m}^{2}$

Elevation: $214^{1}$

Environment: Brush, grasses, riparian vegetation; alluvium.

Evidence: Two distinct sandstone clusters, each about $2 \mathrm{~m}^{2}$; one group has larger stones, averaging $60 \mathrm{~cm}^{2}$ (northern cluster), the other group has stones about $20 \mathrm{~cm}^{2}$; scarce historic debris: brown glass, metal chain fragment, Henry Beard (owner) said these foundations were oil well drilling pads from early 1900s activity. About $8 \mathrm{~m}$ south in a gully area some prehistoric evidence was found: Scallorn arrow point, flakes, a core, and a few mussels.

41 MC 281 (UTSA 77)

Location: Upland ridge $100 \mathrm{~m}$ southeast of Frio River.

Area: $\quad 10,000 \mathrm{~m}^{2}$

Elevation: ' $230-250^{\prime}$

Environment: Upland brush; sand/alluvium, extensive sandstone outcrops.

Evidence: Primarily historic with a light prehistoric scatter; historic evidence: concentration of sandstone (possibly a collapsed chimney), plus another possible stone alignment. Material: centerfire cartridges, glass, earthenware, salt glaze ware, square nails, and ceramic pipe bowl fragments; flakes and core noted.

Comment: Relic collector's pile of historic material observed.

\section{MC 282 (UTSA 78)}

Location: Upland ridge immediately southeast of Frio River.

Area: $22,500 \mathrm{~m}^{2}$

Elevation: $230-245^{\prime}$

Environment: upland brush; alluvium/loam with extensive sandstone outcrops.

Evidence: Primarily historic, with a moderate scatter of prehistoric evidence; historic sandstone rubble accumulations in at least five concentrations, possibly relating to chimney structure; material: iron stove fragments, square nai1, smal1 10op-ended worked iron rod, glass, ginger beer vessel sherd, alkaline glaze sherd, oriental porcelain sherd and decorated earthenware; thick mussel fragment, thin and thick bifaces including Tortugas forms, flakes, and cores. 
41 MC 283 (UTSA 79)

Location: Upland ridge $60 \mathrm{~m}$ south of Frio River.

Area: $10,000 \mathrm{~m}^{2}$

Elevation: $230-245^{\prime}$

Environment: Upland brush; alluvium/sand, extensive sandstone outcrops.

Evidence: Light to moderate historic and prehistoric material. Two possible historic sandstone concentrations exist; white earthenware. (predominantly undecorated), glass, iron plate fragments, and lead glaze rim sherd. Prehistoric pottery, flakes, cores, and a crude biface.

41 MC 284 (UTSA 80)

Location: Upland area $250 \mathrm{~m}$ south of the Frio River.

Area: $\quad 36,000 \mathrm{~m}^{2}$

Elevation: $235-250^{\prime}$

Environment: Moderate cover of upland brush; alluvial soil, sandstone outcrops on valley wall.

Evidence: Historic and prehistoric; one area of historic sandstone (possible chimney rubble); glass pane fragments and bottles, white earthenware (mainly undecorated), a file and other metal fragments; light flake scatter including 2 thick bifaces (one of palmwood), a possible dritl fragment, and a thin biface.

47 MC 287 (UTSA 83)

Location: Floodplain, just west of creek primarily to the Frio. River, about $500 \mathrm{~m}$ north.

Area: $625 \mathrm{~m}^{2}$

Elevation: $220-226^{\prime}$

Environment: Cultivated field; brush along creek banks; alluvium/loam; sandstone outcrops in uplands to the east.

Evidence: This historic site consists of sandstone rubble located in three gullies running into the creek from the cultivated field. These are reported to pertain to a cemetery cairn once located to the west about $25 \mathrm{~m}$, and razed during land clearing. The time, identification, or possibility of subsurface remains is not known, but it was reportedly the grave of one individual. 
41 MC 288 (UTSA 84)

Location: Floodplain; terrace rise $100 \mathrm{~m}$ south of Frio River and west of joining primary creek.

Area: $62,500 \mathrm{~m}^{2}$

Elevation: $200-227^{\prime}$

Environment: Cultivated field; creek-drainage with grass and brush; riverine hardwoods nearby; alluvium/loam; gravel and sandstone outcrops nearby.

Evidence: This site mainly consists of prehistoric evidence. A large light to moderate scatter of flakes, cores, bifaces, and a small amount of burned stone occurs in the highest cultivated field area and reintensifies to the east down on the creek's edge. A low density scatter tapers along the western side of the area for several hundred meters south covering historic sites 41. MC 287 and 41'MC 290. A quartzite hammerstone, 6 thin bifaces, 3 thick bifaces, and a possible Tortugas and Ensor dart point were noted. The cultivated field (western) site area also displays historical material consisting of glass, ceramic, and metal fragments. It may be related to historic site 41 MC 289 nearby to the west.

\section{MC 289 (UTSA 85)}

Location: Floodplain terrace rise, $200 \mathrm{~m}$ south of the Frio River.

Area: $14,000 \mathrm{~m}^{2}$

Elevation: $222-229^{\prime}$

Environment: Cultivated field; riverine vegetation nearby; alluvium/loam.

Evidence: Historic and prehistoric; historic debris consists of a moderate scatter of white earthenware, bottle neck fragments and other glass, metal stove (?) fragments and coffee grinder part, Peters .38-40 and WRA Co. 44XL centerfire shel1s; some of this material also exists in gullies running north of site including some sandstone there; prehistoric debris consists of a light scatter of flakes, a small biface, a thick biface, several cores and burned chert; thick mussel also present.

Comment: A frame house is reported to have stood here as late as the 1930s. A man named Bell from California may have once owned this place (Curtis Dusek, personal communication). Historic and prehistoric material here may link to site 41 MC 288, which is nearby and to the east; a slight drainage separates the two sites.

Location: Floodplain west of primary creek running to the Frio River, about $300 \mathrm{~m}$ north. 
Area: $625 \mathrm{~m}^{2}$

Elevation: $212-216^{\prime}$

Environment: Moderate brush, grasses; alluvial soil, with sandstone outcrops about $400 \mathrm{~m}$ east across the creek on uplands.

Evidence: This historic site exists within the low density prehistoric scatter running south of 41 MC 288. It consists of a sandstone structural alignment about $2.2 \mathrm{~m}$ long, nearly ground level; this may be a chimney remnant, possibly burned soil appears within the intact stone area; other sandstone is scattered downhi11; artifactual debris is scarce, only a few white earthen sherds and a scissors blade.

Comment: This site is not far from the razed cemetery area of 41 MC 287.

41 MC 291 (UTSA 87)

Location: Floodplain terrace rise located within fork of creek which enters the Frio River about $200 \mathrm{~m}$ north.

Area: $6800 \mathrm{~m}^{2}$

Elevation: $210-218^{\prime}$

Environment: Light brush cover and grasses; alluvial soil with abundant gravels and sandstone in vicinity.

Evidence: Site consists of a light to moderate scatter of flakes, cores, burned chert, mussel, snails, and bifaces including 3 crude bifaces, a thin biface fragment, and a unifacial "gouge."

Comment: Prehistoric low density evidence actually continues for several hundred meters south, following the topographic terrace with drainage on either side; also, historic barbed wire was present at this site (Sunderland Kinked single strand, 1884 patent).

\section{MC 292 (UTSA 88)}

Location: Floodplain, minor terrace rise near small flood channels; Frio River is less than $100 \mathrm{~m}$ north.

Area: $5000 \mathrm{~m}^{2}$

Elevation: $202-270^{\prime}$

Environment: Light brush, grasses, riverine vegetation; alluvial soil; major cultivated field nearby south.

Evidence: Light prehistoric scatter consisting of flakes, cores, mussels, snails, bifaces, sandstone, and fire-cracked chert; scatter of sandstone in drainage southeast of site; possible historic component of 41 MC 288. 
41 MC 293 (UTSA 89)

Location: Floodplain terrace rise, immediately south of Frio River and east of a primary drainage (Fig. 12,b).

Area: $\quad 16,900 \mathrm{~m}^{2}$

Elevation: $210-220^{\prime}$

Environment: Cultivated field; light brush and riverine vegetation nearby; alluvium/loam.

Evidence: Evidence is historic and prehistoric. The historic component relates to sandstone placed in gullies off the cultivated field apparently related to clearing the cultivated area. This cultivated edge also displays a heavy scatter of white earthenware and blue-decorated white earthenware, glass fragments including dark green bottles; ginger beer bottle fragments and metal such as square nails, a button and a horseshoe. Some sandstone may yet be in place in the field's edge where a road exists (Fig. 12,b). A light to moderate prehistoric scatter extends here and south for over $150 \mathrm{~m}$, with uncertain boundaries. Material includes flakes, land snail, thick mussel, cores, bifaces, and prehistoric sherds.

\section{LOW DENSITY SCATTERS}

These were usually light scatters of lithic debris not within site density criteria (Table 3). As discussed in the METHODOLOGY section, this is simply one way of dealing with the general nature of cultural evidence in the Choke Canyon region, and does not imply that a given "LDS" is more or less important than what might be a "minimal" site. Many flake scatters are related to natural gravel areas and represented initial testing or decortication of cobbles. Occasionaliy an artifact was termed an Isolated Find (and so numbered) even though it occurred in a Low Density Scatter. These data are plotted on the Bureau of Reclamation maps having a contour interval of two feet and a scale of $1^{\prime \prime}=800^{\prime}$ (on file at CAR-UTSA).

TABLE 3. LOW DENSITY SCATTER DESCRIPTIONS

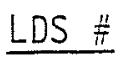

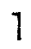

2

3
Description

Flakes, biface (IF 1)*

Flakes, burned rock in large area*

Flake, core fragment, and petrified wood biface in cultivated field*
Study Area 
Table 3. (continued)

$\underline{\text { LDS \# }}$

4

5

6

7

8

9

10

11

12

13

14

15

16

17

18

19

20

21

22

23

24

25
Description

Study Area

Flakes, burned rock, in small area; possibly relates to 41 LK 24 nearby

Flakes; large area; natural grave 1

2

Flakes on stock tank dam

2

Few flakes and burned chert in sendero, 2

Flakes in cultivated field

\section{1}

Flakes in road cut

1

Flakes (LDS \# 10-13, 59 are in an upland area covered by a large thin scatter)

Few flakes

Few flakes; probably related to 41 LK 240

1

Flakes

1

Flakes and core (IF 8)

4

Flakes; small area $\quad 4$

Flakes; small area in road 4

Flakes; probably related to LDS $\# 14$

Flakes, biface fragment* 4

Flakes 4

Historic scatter of glass and metal fragments 4

Flakes

4

Mussel fragments, flakes; extending along terrace between 41 MC 238 and 41 MC 241

5

Flakes

Flakes

5

Flakes (gravel area)

5

FField sketch made of diagnostic artifact 
Table 3. (continued)

LDS \#

26

27

28

29

30

31

32

33

34

35

36

37

38

39

40

41

42

43

44
Description

Flakes, biface fragment; gravel area; associated with 41 MC 239

Few flakes about 41 MC 240 (historic site)

Few flakes, mussel fragments

Flakes, mussel fragments

8

Flakes, mussel fragments; large area, running east and west of 41 MC 247

Light flake scatter

8

Flake scatter extension of 41 MC $248 \quad 8$

Thin biface and a few flakes*

8

A flake and many mussel shells revealed by an armadi170 hole; possible buried materials

8

Flakes on artificial dam; origin unknown

8

Flakes and mussel fragments

8

Flakes

8

Few flakes and bifacial "gouge"*

8

Flakes, mussel fragments, dart point; large area* 8

Flake scatter; large area

8

Flakes; large area; dart point; possible site density or extension of 41 MC 86 *

8 (Salt Branch)

8 (Salt Branch) (Salt
Branch)

7 
Table 3. (continued)

$\underline{\text { LDS \# }}$

45

46

47

48

49

50

51

52

53

54

55

56

57

58

59

60

61

62

63
Description

Study Area

Flakes, musse1, some burned chert; large area running west of 41 MC 262 along Frio River, nearly to 47 MC 267

Flakes, mussel, some burned chert; extending west of 41 MC 267.

Flakes; large area, associated with 41 MC 271, 41 MC 272

Mussel fragments with a few flakes

Burned chert in road cut

3

Mussel fragments

3

Mussel fragments

3

Flakes, mussel; small area (gravel)

Flakes, thin biface; (gravel) large area related to 41 LK 243

Mussel, flakes, snail; small area, possible site density

Flakes, cores (gravel uplands); may relate to 41 LK 245, 41 LK 246

Few flakes, 3 cores (gravel uplands); may relate to 41 LK 245

Flakes, biface fragment; on stock tank dam* ${ }^{\star}$

Flakes, cores, thick biface fragment (gravel uplands) 3

Flakes (upland gravels, near LDS \# 13)

Flakes, burned rock; possibly once a site, could relate to 41 LK 244

Cores (gravel area)

Flakes (gravel area)

Flakes, biface (gravel area) 
Table 3. (continued)

LDS $\#$ Description

Study Area

64

Few flakes, core, thick biface fragmient

(surrounding 41 MC 237, historic site)

\section{Isolated Finds}

The isolated finds (Table 4) represents only a small portion of dispersed cultural materials of this sort in the Choke Canyon Reservoir. Evidence was recorded that failed to achieve a "site" or "low density" classification for any reason. For example, IF $\# 16$ was actually a hearth, but was out of the survey area and could not be thoroughly investigated. More typical isolated finds were stone tools, apparently lost or discarded during prehistoric subsistence activities. Isolated cores were considered possible indicators of lithic procurement activity.

TABLE 4. ISOLATED FINDS

$\begin{array}{llc}\text { IF \# } & \text { Description } & \text { Study Area } \\ 1 & \text { Thin biface* } & 2 \\ 2 & \text { Core } & 2 \\ 3 & \text { Core } & 2 \\ 4 & \text { Core } & 2(1) \\ 5 & \text { Core } & 2(1) \\ 6 & \text { Thick biface* } & 4 \\ 7 & \text { Core } & 2 \\ 8 & \text { Core } & 4 \\ 9 & \text { Thick biface fragment* } & 4 \\ 10 & \text { Thick biface fragment* } & 4 \\ 11 & \text { Core } & 5 \\ 12 & \text { Triangular dart point* } & 5 \\ 13 & \text { Core } & 8\end{array}$

*Field sketch made 
Table 4. (continued)

IF $\#$ Description

Study Area

14

Possible hearth (gully cut near Frio River)

15

Core

16

Hearth (just above 230', out of study area; should be further examined uphi11; 1-2 flakes in general area of thick brush in drainage gut7ies)

Core

In the course of this survey, some previously recorded sites were visited. New information did not always result because examination time often was brief. However, a11 occurrences will be listed in case future researchers might wish to examine our notes. Statements on 41 LK 27 (Fig. 9,a), 41 MC 18, and 41 MC 67 have been turned in to TARL (Austin).

In Study Area 1, many of the sites were relocated along the northern, lower area CAR surveyed. Exact identification was sometimes delayed because animals seemed to be removing the aluminum identification tags from the CRI stakes. Sites 41 LK 174, 41 LK 180, 41 LK 181, 41 LK 192, 41 LK 193, and 41 LK 194 were examined. Sites 41 LK 180, 41 LK 181, and 41 LK 192 were within a low elevation, east-west contour transect of the CAR crew. A triangular biface from $41 \mathrm{LK} 192$ and a possible Guadalupe tool from 41 LK 180 were sketched at their sites. A1so, a large broken metate was photographed at $41 \mathrm{LK} 180$. Site $41 \mathrm{LK} 174$ is probabily related to 41 LK 241 , that CAR recorded nearby. Sites 41 LK 194 and 41 LK 193 had dart points and other bifaces field sketched. The latter site seemed to have more area than was shown on the map. Remnants of other sites which were largely destroyed by State Highway 72 construction were 41 LK 203, 41 LK 204, 41 LK 205, and 41 LK 206; these often displayed light traces of lithic procurement activity.

Near the Pleistocene terrace floodplain of northern Area 2, 41 LK 27 was given a western extension. One distinct area here was of site density for our survey, but it was obvious from the map that 41 LK 27 had been restricted by the property line and otherwise would have included this area. Generally, a light flake and burned chert scatter was noted. A small triangular biface and a biface fragment were sketched. Also in Area 2, 41 LK 24 and historic 47 LK 73 were examined. 
In Area 3, 41 LK 87 was crossed over as a group survey ended. Coincidentally, this site was soon tested by a separate CAR crew.

In Study Area 5, two sites were near its southern boundary, 41 MC 66 and 41 MC 67. The former was inspected by Robert Stiba, who reported a light prehistoric scatter near the historic cemetery. Site 41 MC 67 was visited by the crew after Curtis Dusek reported that an unrecorded historic "dug out" was located at this prehistoric site, cut into the sandstone hill where a modern house recently stood. Artifactual traces suggest possible Yarbrough Bend community occupation.

As part of 41 MC 18, the Yarbrough graves reported by the Texas Historical Commission were examined and recorded in Study Area 7. A Bureau survey line runs directly through this cemetery, which was not further disturbed because Curtis Dusek notified the workers. Henry Dusek remembers the former appearance of this cemetery before it was chained over in recent years (UTSA notes, sketch). Today mesquite and other brush have substantially grown up. Two toppled, engraved tombstones are seen in a concentration of scattered sandstone (Fig. 15). A low fence of sandstone with barbed wire was reported once present. Inscriptions give this information: "In Memory' of J. S. Yarbrough, Died October 20, 1862, Age 88 Yrs." and "In Memory of Francis Ya . . [Yarbrough], Died . . 13, 1868, Age 55 Yrs." An infant's tombstone was said to be nearby, but traces could not be identified. A smal1 upright stone (foot marker?) was intact. The fragmented tombstone pieces have been refitted horizontally, script up (Fig. 15). Based on Henry Dusek's memory and our observations, chaining dragged east to west, and the original graves are immediately east of where the tombstones and densest rubble now exist. A few earthenware sherds were also seen in the 10cality, in addition to the light prehistoric scatter of 41 MC 18. The easternmost edge of 41 MC 19 (prehistoric) was also briefly examined.

In Study Area 8, the western end of 41 MC 83 was surveyed by White and Lukowski. An Ensor dart point was noted and sketched.

Finally, on the Jambers property, 47 MC 63 (tested by a Texas A\&M crew) was briefly walked over by Dusek, Roemer, and Stiba.

\section{INTERPRETATIONS}

This section will discuss the significance of the archaeological material recorded by the CAR-UTSA survey.

The context of this survey's results is best considered with regard to the findings of the Texas Historical Commission (Lynn, Fox, and O'Malley 1977), Texas Tech University (Thoms, Montgomery, and Portnoy 1981 and Everett 1981), and CAR/UTSA (Ha11, Graves, and Black 1981). These combined works furnish a good background for understanding the cultural sequence of the Choke Canyon Reservoir area. To avoid repetition, this present report has often assumed the reader's familiarity with these sources. A final, relatively 


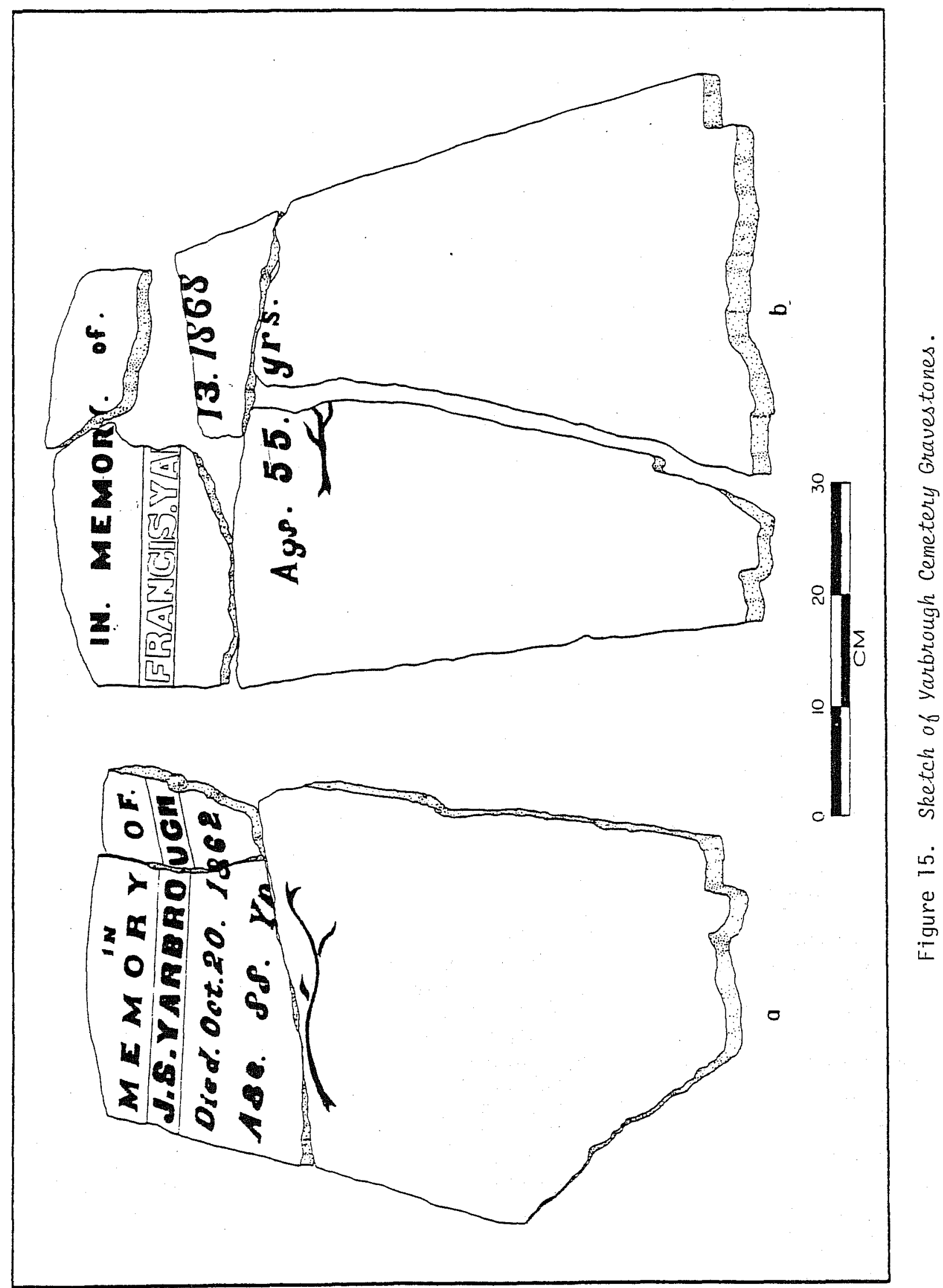


sma11, portion of data has been presented to round out the framework established by this earlier research.

The archaeological evidence may be viewed from two perspectives: prehistoric and historic. The general evidence of prehistoric activity was most often areas of concentrated Tithic debris that pertained to two activities: stone tool manufacturing or use and hearth building. Lithic debris in the form of flakes, cores, and tools was common at the prehistoric sites. Burned rock existed in.light, wide scatters grading to concentrations considered distinct hearths. Additional cultural material consisted of mussel shells, land snails, potsherds, and animal bone fragments. Mussel shells primarily reflect food procurement, but occasionally they may have been tools or ornaments (e.g., the perforated mussel shell umbo at 41 MC 234). Land snails are a common occurrence at southern Texas prehistoric sites. They may have been attracted by prehistoric organic residue, but credence also exists for their importance as a food source (cf. Hester and Hill 1975:16; Campbell and Campbe11 1981). Although ceramics were once considered practically nonexistent in southern Texas, field workers in the Choke Canyon area have come to realize that pottery is present, even though the evidence at a site often involves only a small single potsherd. Bone was poorly preserved in most sites in this survey.

The lithic tools and hearth building evidence confirm the general assumption of southern Texas archaeologists that hunting-gathering lifeways existed in the southern Rio Grande Plain area from the time of the earliest known human occupations. Although variation took place, the general scene is that of small bands or family groups inhabiting and traversing the survey area. Food, shelter, utensils, and heating fuel were obtained from the environment at hand: plants, animals, water, and lithic outcrops. The abundant, local natural gravels were continualiy utilized in making tools. Burned rock is included in these gravels, also sandstone and Catahoula tuff stone. Function of the hearths probably involved food processing. Other benefits included bodily warmth and protection from insects. Evidence of thermal treatment in the lithic tool-manufacturing process was not seen in this survey but possibly took place. The concentrations of cultural debris were frequent (one site for each 89 acres--36 hectares--surveyed). Sites and low density scatters were very widespread, but site locations adjacent to water drainages also become obvious. Convenience of potable water was an important criteria for the aborigines of the area, although such water resources may be shown now only by minor, intermittent drainages. The available plant and animal resources also required group mobility for the hunter-gatherers to be efficient. Seasonality determined some regularity of activities. Stone tools observed in this survey indicate specific lifeway functions, such as the projectile points for hunting and possibly defense, and the "gouge" and grinding stone forms for plant or animal processing. Furthermore, incorporating other archaeological investigations (cf. Ha11, Graves, and Black 1981), tool forms such as Ensor dart points provided some chronological indications. Based on what little was found, it is probable that an extent of prehistoric activity dates from European contact back at least 5000 years. The bulk of this falls in the Archaic, 
especially the Late Archaic division. A distinction was made at the sites exhibiting Late Prehistoric arrow points or pottery. These traits are assumed to have been introduced at ca. A.D. 1000 with some probably continuing well after A.D. 1500 into the Historic period (as evidenced by a metal arrow point known from 41 LK 31 and 41 LK 32).

Sites with dominant historic evidence constitute about 12 percent of the total recorded by the CAR-UTSA survey. These sites most often exhibited scatters of glass, earthenware, and metal fragments, sometimes in conjunction with structural evidence. Because there are fewer sites, more detailed discussion will take place.

Sites 41 MC 229 and 41 MC 230 were the two most recent historical sites, probab7y no earlier than 1910-1920, and only recently abandoned. A man with a Hispanic surname lived at 41 MC 229 at one time (local information), and this may have a bearing on the Mexico-ware sherds collected here. This site had a good array of mule-drawn farming equipment, presently under negotiation for public preservation. The surrounding land, currently some of the more cleared and productive farmland in the reservoir, probably indicates that these homesteads were the major farming operations of this area in recent times.

Site 41 MC 237 represents recent historical activity, possibly a forge of some type.

The historic component of 47 MC 67 (outside the survey area) possibly relates to the Yarbrough Bend community of the 1860-1880s period. A basic one-family habitation is suggested. This "dug out" type construction is not well known historically or archaeologically in the area.

The oil well site of 41 MC 240 may be one of the Byrne family's early projects (from 1908 on; Everett 1981). Research on this type of historic site would be aided by the Bureau program of well inspection and containment. Site 41 MC 264 has sandstone blocks used as a drilling pad (Henry Beard, personal communication).

The nearly continuous historic sites on the south side of the Frio River before the San Miguel Creek confluence appear to represent a portion of the Yarbrough Bend community, with some Tater occupation. These are 41 MC 282, 41 MC 283, 41 MC 284, 41 MC 287, 41 MC 288, 41 MC 289, 41 MC 290, and 41 MC 293. Most of these sites display earthenware, glass, and structural remnants compatible with the 1860-1880s period, with some evidence of post-1900 occupation at 41 MC 284 and 41 MC 289. A preference for a variety of earthenware artifacts, especially white or blue-trimmed white, gives some indication of cultural values. Site 41 MC 293 may represent one of the wealthier, leading residences within the Yarbrough Bend area. The prolific historic sites in this survey area create a "community atmosphere, " supported by the structural remnants at 41 MC 281, 41 MC 282, 41 MC 283, 41 MC 290, and 41 MC 293, and the cemeteries, 41 MC 287 and 41 MC 18 (revisited). The latter, known as the Yarbrough Cemetery, yielded important information. Only the markers of J. S. and Francis Yarbrough were to be seen. According to Everett (1981), at least 10 other individual graves should have been identified. Two markers should have been visible stating: "Infant Daughter of 
Joseph Walker and Amanda Yarbrough" and "Sorrow-Zevish Died July 2, 1874." A Yarbrough descendent, Mrs. Gladys Ritter (San Antonio), recorded this information in 1964. Visibility in 1979 was poor, but stone cairns are difficult to miss. It is possible that removal of. stone has occurred since 1964.

These Yarbrough Bend historic sites have no available information to refine our knowledge of the patterns of livelihood. The general hypothesis is still that these settlers supported themselves by a combination of farming, hunting, and ranching (cf. Lỳnn, Fox, and O'Malley 1977:175176).

The last historic site to be mentioned is 41 MC 256. This location was apparently 1 imited to dump activity from post-1900 times, probably related to the Horton ranch operation.

Significant aspects of the material recorded by this survey fit into three categories: basic data gathering, evaluation for site recommendations, and new information for understanding the cultural past of Choke Canyon. The first two categories are discussed in the bulk of this report; the third category is discussed in the following pages.

Through the course of any good field work, basic questions are the background for the archaeologist's thoughts as the evidence is examined. Some of the long range goals pertinent to the Choke Canyon Reservoir were summarized in the technical proposal for this survey (A Proposal for Cultural Resource Survey and Evaluation in the Choke Canyon Reservoir, Live Oak and McMullen Counties, Texas; Solicitation No. 5B-V0527, Part I, CAR-UTSA 1978). Seven problem-oriented areas are 1isted: Chronological Framework, Subsistence Systems, Settlement Systems, Technological Systems, Tool Kits, Territoriality, and Paleoenvironment. Some of these areas are beyond the scope of this immediate survey. Many may be affected by the results of further evaluation.

Surface erosion, mixed evidence, and lack of preservation are some of the limits of surface surveys. Despite this, the notions of chronology and settlement systems are most readily addressed by this recent CAR survey. Even if jumbled, chronologically distinctive artifacts can be identified. Though scarce, such indicators were located by this survey, and that data confirmed the basic framework of the earlier workers. A slightly higher frequency of Late Prehistoric diagnostic artifacts was seen, but, due to several uncontrollable biases, a cultural trend is not assigned at this time. One such bias may be credited to relic collectors, who probably determined the infrequent occurrence of other artifact forms and the lack of Paleo-Indian tools.

Settlement systems pertain to site distribution and function. Material evidence usually retains original areal patterning, unless environmental actions are extremely detrimental. Site function is assigned according to the nature of the evidence and, reasonably, should relate to natural resources and neighboring site activities. 
The high number of recorded sites (ca. 400) in the Choke Canyon area should allow new statements to be formulated on southern prehistoric settlement patterns. Four general models from earlier work may be considered here.

The first is that of Hester (1976b:6), based on work in Zavala County:

The floodplain living sites were obviously the base camps during the seasonal subsistence rounds. They were situated in a rich riparian microenvironment and were located close to reliable water sources. From these camps, smal1 parties of hunters and foragers could go out into the terrace and upland areas.

This model predicted specialized or limited evidence at certain types of sites away from major drainages.

The second model based on field work in Atascosa and McMullen Counties is that of Shafer and Baxter (1975:73), who found sites that indicated multiple activity in upland situations or away from prominent water drainages. They proposed (ibid.):

Since water is available during the wetter seasons and years in the uplands and assuming that the distribution of water was a determining factor in settlement location, it is proposed that the prehistoric hunting and gathering bands could establish their encampment anywhere that water was available. Therefore the multiple activity sites need not be restricted to the better watered areas although over time these areas would see the most intensive utilization.

The Texas Historical Commission archaeologists agreed with Shafer and Baxter and presented their own view of the Choke Canyon prehistoric settlement pattern (Lynn, Fox, and O'Ma17ey 1977:171-172):

The sites within the reservoir appear to be the result of repeated occupation by bands of people inhabiting generalized site locales rather than a specific location...

Most recently, the Texas Tech University survey discussed settlement patterns in the reservoir (Thoms, Montgomery, and Portnoy 1981). This discussion followed the distributive predictions on the water-site model of Shafer and Baxter, but aspects of seasonality were refined, suggesting a dichotomy between (1) low elevation, major drainage occupation in the dry late winter, early spring, and mid-summer periods, and (2) higher elevation, minor drainage, or upland occupations in the wet periods of April to June and August to November. 
Site function is the other major element for understanding settlement systems. Classification is most often based on careful examination of individual artifacts, groups of artifacts, and features which may reflect past activities. Through surface and excavation collections, earlier researchers formulated a variety of opinions based on in-depth analysis. Shafer and Baxter (1975:69-72) classified sites into three groups based on artifactual content: "Multiple Function, Limited Function, and Resource Procurement." These groups basically reflected the range of quantity and variation of lithic tools, knapping debitage, and burned rock at any given site. The "Resource Procurement" term was similar to that of "Limited Function," but evidence suggested specialized procurement localities. Relatively few of these sites were identified. The total site groups were considered tentative and overlapping.

The THC archaeologists did not classify sites into functional groups. Rather, Lynn, Fox, and O'Ma11ey (1977:221) state that:

Throughout the prehistoric period, site locations appear to reflect the same general activities in all physiographic settings. Evidence of hearth building, mussel exploitation, and a11 phases of 1ithic tool manufacturing occur at virtually every site recorded.

The THC workers also felt that major climatic shifts (and corresponding environmental changes) would be reflected in the archaeological record at Choke Canyon (ibid.:219-223), but as the CRI report points out, southern Texas paleoenvironmental data are sti1l lacking (Thoms, Montgomery, and Portnoy 1981).

Site function at CRI sites was first examined through the use of site grouping with some implied activities. This was a fairly arbitrary division of computer information into five classes. Much of this was based on environmental attributes and material from tested sites (Lynn, Fox, and 0'Malley 1977:292-294). Simplified, the first class consisted mostly of large area sites, near permanent water, with many and varied artifacts. The second class was large sites, distant from permanent water, with many and varied artifacts. The third class consisted of smal1 sites (the majority of the CRI sites), distant from permanent water, with fewer artifacts. The final prehistoric class showed distinctive lithic reduction activity, in appropriate areas of abundant natural 1ithics. The fifth class was historic. The CRI report goes on to present a well-planned model for settlement and subsistence, plus ideas for testing, based on particular data and general theories (ibid.:305-308).

The previous archaeological information integrates with the present CAR survey, forming a relative conclusion to site documentation for the reservoir area. This must be especially considered in view of settlement system formulation, taking in the whole of the reservoir's ca. 400 sites.

The THC survey viewed many sites as "occupation zones" or "linear accumulations of campsite debris paralleling a stream channel" (cf. Hester 
1976a: 85). Future researchers were expected to isolate site activity areas, probably of different times and people. However, CAR and CRI workers had a limited definition for the remainder of the reservoir. Any consistency would require going over site forms and later evaluation, hoping to find some way to evaluate and equalize THC sites. This involves defining site limits, a difficult Choke Canyon problem noted by all earlier workers. As a result, most site areas are not exact enough to be used for detailed comparisons. For landform associations it would seem easier, but the identification of transition areas between the lower valley wall and upper floodplain, for example, was sometimes difficult for the CAR crew. This indicates that careful reexamination of data between even the CRI and CAR sources would be needed, still. leaving the majority of the reservoir area to be considered.

It is felt that a comprehensive approach is still possible, but would be better served after a maximum of information is in from all Choke Canyon archaeological evaluation (including this survey's recommended sites). The following suggestions, therefore, are made:

1. In consideration of the continued relationship of site evidence to water sources, a systematic classification of drainages is needed. Terms such as "primary," "secondary," or "minor" have not been standardized for reservoir archaeologists. Researching hydrologic standards may aid, or some type of very sma11 volume or arbitrary map scale classification could be estimated. More research is needed for explaining small drainage capacities of the past, a subject that appears very speculative but important to the CRI settlement model. For example, what exactiy is "distant water," and how does this concept work in aboriginal systems elsewhere?

2. More information on upland sites is still needed. Unfortunately, the reservoir area below the 233-foot elevation precludes most of this area. If more upland area cannot be inspected with regard to future Bureau of Reclamation land use, alternative means for investigation should be attempted.

In conclusion, the basic cultural synthesis found by earlier studies is verified by the CAR survey Prehistoric sites displaying mainly scatters of stone tools and manufacturing debris, burned rock, and mussel shell continue to be dominant, and reflect the notion that smal1, mobile groups of hunter-gatherers utilized the entire study area. Some amount of hearth building and Tithic knapping activity is present at almost every site. Sites with larger areas and denser artifact frequencies often do exist near major water channels, but substantial, varied evidence may exist at other locations. It is interesting to note how few areas of the reservoir are without some prehistoric traces. The presence of the Low Density Scatters or Isolated Finds may indicate long term environmental disturbance or widespread limited amounts of cultural activity. It is possible that these occurrences represent significant, temporary resource procurements. The constant reuse of the Choke Canyon area, with al1 essential resources immediately available, probably resulted in the 
relative homogeneity of sites seen by the CAR survey. Based on sites in Arkansas, Schiffer (1975) provides a discussion of the uniformity phenomenon of surface evidence, and other considerations applicable to this reservoir's interpretation.

Historical aspects of the CAR survey also basically support the findings of earlier workers. The most important new information exists in Study Area 7 south of the Frio River. A relative density of evidence for the Yarbrough Bend community and later occupation existed on the southern side of the river for approximately $2.4 \mathrm{~km}$ west of the San Miguel Creek confluence. A notable lack of historic evidence is immediately apparent on the northern side of the Frio River, although a historic river,crossing is present at 41 MC 286. The census researched by Everett (1981) provides a guide to be considered in future evaluation of these sites, which may constitute a major segment of this important, yet poorly known, pioneer community.

\section{ACKNOWLEDGMENTS}

The author thanks the following persons for their support: Curtis Dusek, Grant D. Ha11, Mary Lehr, Paul Lukowski, Robert Oram, Robert Stiba, and Don White. Carol Graves, Thomas R. Hester, Sharon Quirk, Mary Lou Ellis, and $A 1 \mathrm{~B}$. Wesolowsky aided in editing. Typing of the draft manuscript was done by Brenda Brinkman and Carmel Y. Graham. Patricia Wallace typed the final manuscript copy. 


\section{REFERENCES CITED}

Black, S. L.

1978 Archaeological Investigations at the Banquete Bend Site

(41 NU 63) Nueces County, Texas. Center for Archaeological Research, The University of Texas at San Antonio, Archaeological Survey Report 63.

1981. Analysis of Prehistoric Ceramics. In Archaeological Investigations at Choke Canyon Reservoir, South Texas: The Phase I Findings, by G. D. Hal1, C. Graves, and S. L. Black. Center for Archaeological Research, The University of Texas at San Antonio, Choke Canyon Series 5.

Blair, W. F.

1950 The Biotic Provinces of Texas. Texas Journal of Science 2(1):83-117.

1952 Mammals of the Tamaulipan Biotic Province in Texas. Texas Journal of Science 4(2):230-250.

Bryant, V. M., Jr.

1966 Preliminary Studies of the Late Quaternary $\mathrm{Cl}$ imates in the Amistad Reservoir Area of Southwest Texas: The Pollen Evidence. In A Preliminary Study of the Paleoecology of the Amistad Reservoir Area, assembled by D. A. Story and V. M. Bryant, Jr.: 154-156. Final report of research under the auspices of the National Science Foundation (GS-667).

Bryant, V. M., Jr. and D. A. Larson

1968 Pollen Analysis of the Devil's Mouth Site, Val Verde County, Texas. Papers of the Texas Archeological Salvage Project, The University of Texas at Austin 14:57-70.

Bryant, V. M., Jr. and H. J. Shafer

1977 The Late Quarternary Paleoenvironment of Texas: A Model for the Archeologist. Bulletin of the Texas Archeological Society $48: 1-25$.

Campbe17, T. N. and T. J. Campbe11

1981 Historical Indian Groups of the Choke Canyon Reservoir and Surrounding Area, Southern Texas. Center for Archaeological Research, The University of Texas at San Antonio, Choke Canyon Series 7 . 
Center for Archaeological Research

1978 A Proposal for Cultural Resource Survey and Evaluation in the Choke Canyon Reservoir, Live Oak and McMullen Counties, Texas; Solicitation No. 5B-V0527, Part I: Technical proposal submitted to the Bureau of Reclamation by the Center for Archaeological Research, The University of Texas at San Antonio.

1979 Final Recommendations for Phase II Archaeological Investigations in the Choke Canyon Reservoir, Nueces River Project, Texas. Center for Archaeological Research, The University of Texas at San Antonio.

Collins, M. B.

1975 Sources of Bias in Processual Data: An Appraisal. In Sampling in Archeology, ed. J. W. Mue11er:26-32. University of Arizona Press, Tucson.

Creel, D., A. J. McGraw, F. Valdez, Jr., and T. C. Kelly

1979 Excavations at 41 LK 106, A Prehistoric Occupation Site in Live Oak County, Texas. Center for Archaeological Research, The University of Texas at San Antonio, Archaeological Survey Report 62 .

Epstein, J. F.

1969 The San Isidro Site: An Early Man Campsite in Nuevo Leon, Mexico. Department of Anthropology. The University of Texas at Austin, Anthropology Series 7.

Everett; D.

1981 Historical Resources of the Choke Canyon Reservoir Area in McMulien and Live Oak Counties, Texas, Part I. Center for Archaeological Research. The University of Texas at San Antonio, Choke Canyon Series 2.

Gunn, J. and R. Mahula, eds.

1977 Hop Hil1: Culture and Climatic Change in Central Texas. Center for Archaeological Research, The University of Texas at San Antonio, Special Report 5.

Ha17, G. D., C. Graves, and S. L. Black

1981 Archaeological Investigations at Choke Canyon Reservoir, South Texas: The Phase I Findings. Center for Archaeological Research, The University of Texas at San Antonio, Choke Canyon Series 5 . 
Hester, T. R.

1976a The Archaic of Southern Texas. In The Texas Archaic: A Symposium, ed. T. R. Hester:83-90. Center for Archaeological Research, The University of Texas at San Antonio, Special Report 2 .

1976b Hunters and Gatherers of the Rio Grande Plain and the Lower coast of Texas. Center for Archaeological Research, The University of Texas at San Antonio.

1980a A Chronological Overview of Prehistoric Southern and SouthCentral Texas. In Papers on the Prehistory of Northeastern Mexico and Adjacent Texas, ed. J. F. Epstein, T. R. Hester, and C. Graves:119-138. Center for Archaeological Research, The University of Texas at San Antonio, Special Report 9.

$1980 b$ Digging Into South Texas Prehistory. Corona Publishing Co., San Antonio.

Hester, T. R. and T. C. Hi11, Jr.

1975 Some Aspects of Late Prehistoric and Protohistoric Archaeology in Southern Texas. Center for Archaeological Research, The University of Texas at San Antonio, Special Report 1.

Hester, T. R., L. D. White, and J. White

1969 Archeological Materials from the OulTine Site (41 LS 3) and Other Sites in La Salle County, Southwest Texas. The Texas Journal of Science 21(2):131-166.

Johnston, M. C. and D. J. Darr

1977 Vegetational Survey, Appendix VI. In Cultural Resource Survey of Choke Canyon Reservoir, Live Oak and McMullen Counties, Texas by W. M. Lynn, D. E. Fox, and N. O'Malley. Texas Historical Commission, Office of the State Archeologist, Archeological Survey Report 20.

Lynn, W., D. E. Fox, and N. O'Malley

1977 Cultural Resource Survey of Choke Canyon Reservoir, Live Oak and McMullen Counties, Texas. Texas Historical Commission, Archeological Survey Report 20.

Schiffer, M. B.

1975 An Alternative to Morse's Dalton Settlement Pattern Hypothesis. Plains Anthropologist 29(70):253-266. 
Schiffer, M. B., A. P. Sullivan, and T. C. Klinger

1978 The Design of Archaeological Surveys. World Archaeology 10(1): $1-28$.

Shafer, H. J. and E. Baxter

1975 An Archeological Survey of the Lignite Project, Atascosa and McMullen Counties, Texas. Texas AEM University. Anthropology Laboratory Report 7.

Sollberger, J.. B.

1971 A Technological Study of Beveled Knives. Plains Anthropologist $16(53): 209-218$.

Suhm, D. A. and E. B. Jelks

1962 Handbook of Texas Archaeology: Type Descriptions. Texas Archeological Society, Special Publication 1 and Texas Memorial Museum Bulletin 4. Austin.

Thoms, A. V., J. L. Montgomery, and A. W. Portnoy

1981 An Archaeological Survey of a Portion of the Choke Canyon Reservoir Area in McMullen and Live Oak Counties, Texas. Center for Archaeological Research, The University of Texas at San Antonio, Choke Canyon Series 3.

Thornwaite, C. W.

1948 An Approach Toward a Rational Classification of Climate. Geographical Review 38:59-94.

Wakefield, W. H.

1968 Archeological Surveys of Palmetto Bend and Choke Canyon Reservoirs, Texas. Texas Archeological Salvage Project, The University of Texas at Austin, Survey Report 5. 
ARCHAEOLOGICAL SURVEY ACTIVITIES AT CHOKE CANYON RESERVOIR

\section{THC Survey}

Season and Year

Cost

Area

Type

\section{Method}

Technique

Collection

Procedure

Interval Between

Surveyors

Number of Person

Days in Field

Rate of Coverage

(per person day)

Site Definition

Number of Sites

Recorded

Site Size Range
Spring 1974 and 1976

Approximately $\$ 43,000$

10,931 hectares

(27,000 acres)

Intensive

Pedestrian

Undefined

Site-specific

provenience

Undefined

208 (approximateTy)

53 hectares

(131 acres)

Undefined

161

$10,000 \mathrm{~m}^{2}$ to $600,000 \mathrm{~m}^{2}$
CRI Survey

Fa11 1977

Approximately $\$ 43,000$

2544 hectares

(6285 acres)

Intensive

Pedestrian

Zigzag transect

No collection during survey

65 meters

128

20 hectares

(49 acres)

More than 10 artifacts

in a $25-\mathrm{m}^{2}$ area

113

$5 \mathrm{~m}^{2}$ to $385,000 \mathrm{~m}^{2}$
CAR Survey

Late Spring, Summer 1979

Approximately $\$ 32,900$

3400 hectares

(8400 acres)

Intensive

Pedestrian

Variable zigzag transect

Minimal collection, provenienced, surface only

50-75 meters

159

21 hectares

(53 acres)

More than 10 artifacts

in a $25-\mathrm{m}^{2}$ area

94

$400 \mathrm{~m}^{2}$ to $125,000 \mathrm{~m}^{2}$ 
THC Survey

Overall Site
Density

Low Density Scatter Definition

Number of Low

Density Scatters

Number of Isolated

Artifacts

General Location of Cultural Resources
14.7 sites per $1 \mathrm{sq} \mathrm{km}$ 3.8 sites per section (640 acres)

Undefined

0

0

Most sites along river and major tributaries, few away from major drainage

\section{CRI Survey}

43.5 sites per $1 \mathrm{sq} \mathrm{km}$ 11.4 sites per section (640 acres)

Fewer than 10 artifacts in a $25-m^{2}$ area

43

5

Sites along river and major tributaries, but most away from major drainage
CAR Survey

36 sites per $1 \mathrm{sq} \mathrm{km}$ 7.2 sites per section (640 acres)

Fewer than 10 artifacts in a $25-\mathrm{m}^{2}$ area

86

20 .

Sites along river, major and minor tributaries 
THE UNIVERSITY OF TEXAS AT SAN ANTONIO Center for Archaeological Research

Site Survey Record
Permanent Number

Field Number

Site Name

Project

Recorder County Map Name

Map Coordinates Location:

Description of Site:

Size Shape Type

Nature of Archaeological Evidence

Features

Vegetation

Soits

Topography

Present condition

Name and address of owner

Activities of Recorder at Site (describe the nature of the investigations, what was done and methods used)

Materials from Site (1ist artifacts and other materials collected or observed at site; sketches should be made on a continuation sheet)

No. of Bags

Photographic Records

No collection made

Black-and-White color

Recommendations

Disposition of notes and collections

Date 
Center for Archaeological Research

The University of Texas at San Antonio

SITE SURVEY CODING FORM

INSTRUCTIONS: If there are any blanks when you walk away from a site, you did something wrong.

Absent $=0$ Present $=1$ (unless otherwise specified)

LOCATION

$$
\underline{0} \text { Card }
$$

- Site No.

------ East Coordinate

- North Coordinate

Elevation

COMPONENTS (Field Estimates)

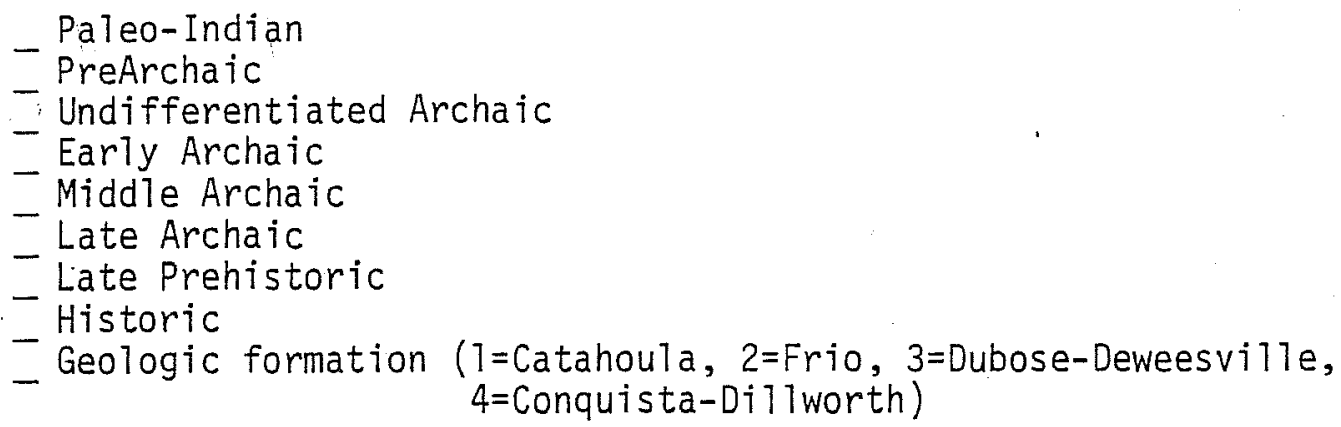

SITE ENVIRONMENT

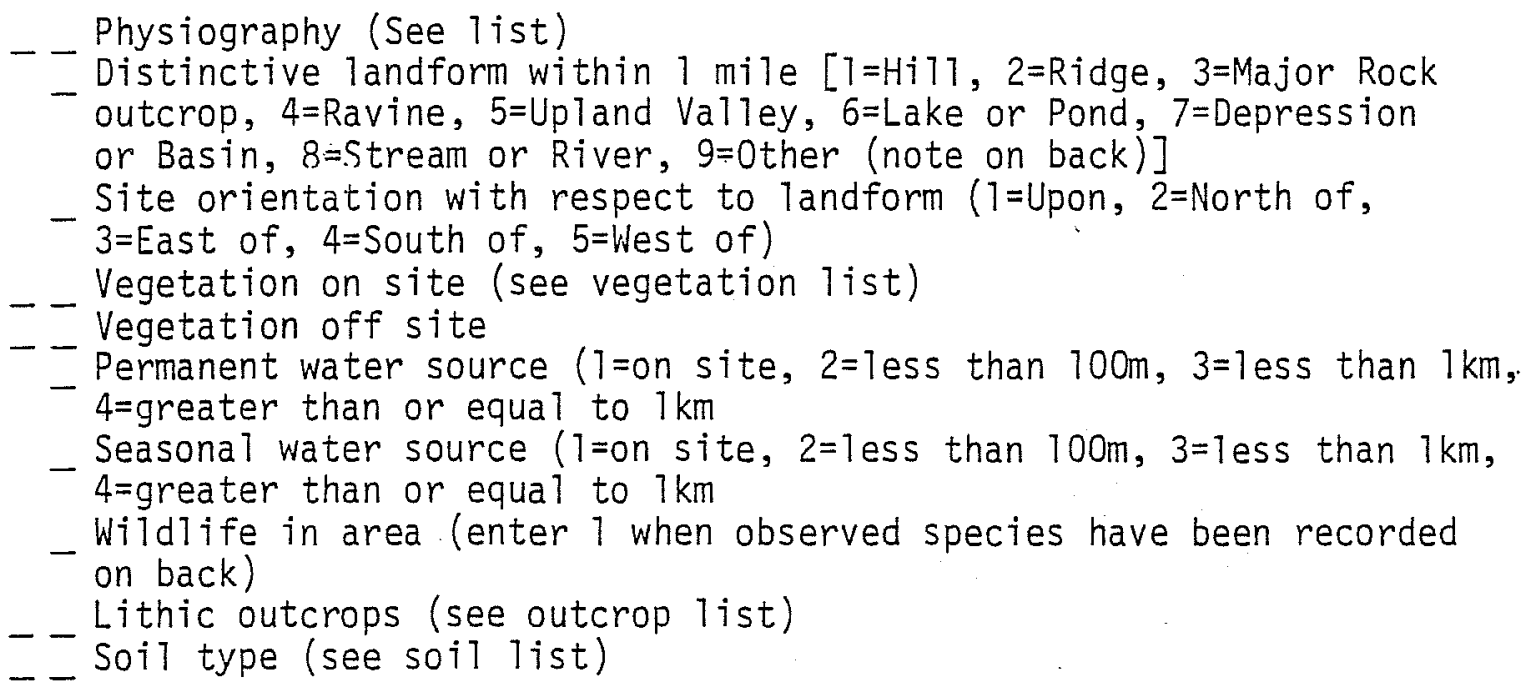

SITE DIMENSIONS

_. Long orientation (degrees East of North)

- Meters long

- - Meters wide 
_ Visibility (1=poor, $2=$ moderate, 3 =good)

- Collecting of site ( $7=$ surface collected, $2=$ potholed, $3=$ destroyed

- by human activity)

- Economic Activity (1=undisturbed, 2=partially disturbed,

- $3=$ wholly disturbed)

- Erosion ( $1=$ und isturbed, $2=1$ ight, $3=$ =moderate, $4=$ heavy)

CULTURAL DEPOSITS

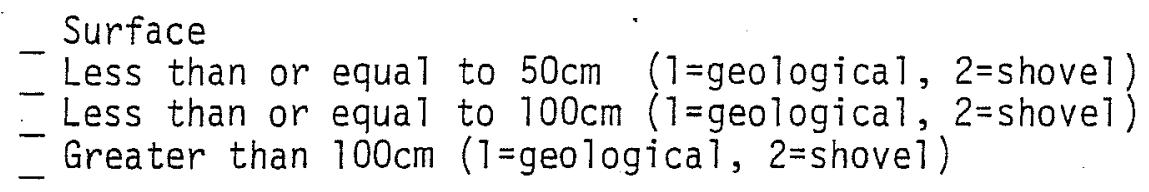

ARTIFACT DENSITY (Site Wide)

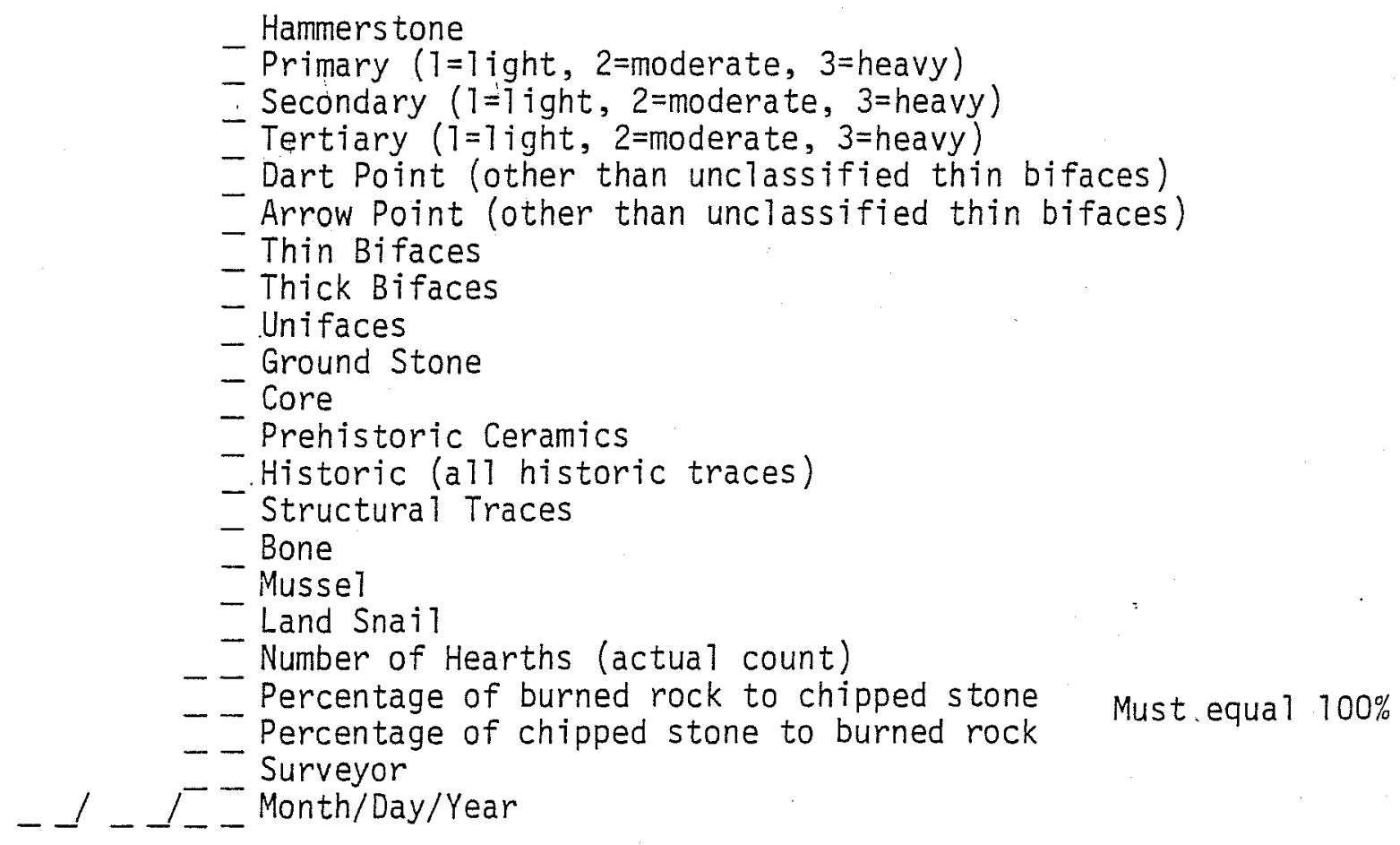

LANDFORM ASSOCIATION (PHYSIOGRAPHY)

1. Floodplain-by river

2. " "-by slough

3. " "by river and slough

4. " " -by primary drainage

5. " " -by secondary drainage

6. Pleistocene terrace

7. Pleistocene terrace-by river

8. " " -by slough

9.

10. -by river and slough

-by primary drainage
11. Pleistocene terrace-by secondary drainage

12. Valley wall

13. Valley wall-by river

14. " "by slough

15. " "-by river and slough

16. " "-by primary drainage

17. " " -by secondary drainage.

18. Upland

19. Upland-by primary drainage

20. "-by secondary drainage 
SITE SURVEY CODING FORM (continued)

DISTINCTIVE LANDFORM(S) (Any unusual landform/feature which might have attracted prehistoric inhabitants to the area)

1.

2.

3.

WILDLIFE LIST (Enter 1 for a 11 wild1ife directly or indirectly noted to be present in the site area)

\begin{tabular}{|c|c|c|c|}
\hline $\begin{array}{l}\text { - Deer } \\
\text { - Turkey } \\
\text { - Javelina } \\
\text { - Armadil10 } \\
\text { Skunk } \\
\text { - Raccoon } \\
\text { Turtle } \\
\text { Fish } \\
\text { - Rodents } \\
\text { Jackrabbit } \\
\text { - Cottontai7 } \\
\text { Quail } \\
\text { Opossum } \\
\text { - Ring-tailed Cat } \\
\text { Fox Squirrel } \\
\text { - Ground Squirrel } \\
\text { - Coyote }\end{array}$ & $\begin{array}{l}\text { Hawk } \\
\text { - Mexican Eagle } \\
\text { - Buzzard (Vulture) } \\
\text { - Canadian Goose } \\
\text { - Scaled Quai1 } \\
\text { - Bob White } \\
\text { - Woodpecker } \\
\text { - Roadrunner } \\
\text { - Curved Bi11 } \\
\text { - Thrasher } \\
\text { - Pyrrhuloxia } \\
\text { - Duck } \\
\text { - Cardinal } \\
\text { - Summer Tanager } \\
\text { - Goldfinch } \\
\text { - Swallow } \\
\text { - Owls }\end{array}$ & $\begin{array}{l}\text { Fox } \\
\text { - Lizard } \\
\text { - Harris Hawk } \\
\text { - Red-Tailed Hawk } \\
\text { - Dove } \\
\text { - Tortoise } \\
\text { - Horned Lizard } \\
\text { - Mussels } \\
\text { - Frogs } \\
\text { - Night Hawk } \\
\text { - Scarlet Tanager } \\
\text { - Wasps } \\
\text { - Warbler } \\
\text { - Rattlesnake } \\
\text { - Cotton Mouth } \\
\text { - Coral Snake } \\
\text { - Western Ribbon } \\
\text { - Snake }\end{array}$ & $\begin{array}{l}\text { Other Snakes } \\
\text { - Mockingbird } \\
\text { - Roseate Spoonbi11 } \\
\text { - Blue Heron } \\
\text { - Osprey } \\
\text { - Alligator } \\
\text { - White Egret } \\
\text { - Western Meadowlark } \\
\text { - Swamp Rabbits } \\
\text { - Bobcat } \\
\text { - White Crane } \\
\text { - What }\end{array}$ \\
\hline
\end{tabular}

\section{LITHIC OUTCROP LIST}

1. River cobbles/gravels, very fine chert, translucent (Class I)

2. " " " medium fine chert (Class II)

3. " " " " " " coarse grained chert (Class III)

5. Slope or upland source, Class I, nodular

6.4 " "CTass II, nodular

7. " " Class III, nodular

8. Sandstone, tabular

9. ", monolithic tuffaceous

10. Chalcedony

11. Petrified/opalized wood

12. Limestone

13. Slope or upland source, Class II $_{11}$, nodular, Sandstone, tabular monolithic tuffaceous

15. Slope or upland source, Class II, nodular, Sandstone, tabular, Petrified/ opalized wood

16. Slope or upland source, Class II $_{11}$, nodular, Sandstone, monolithic tuffaceous
17.

, Chalcedony, Limestone 
SITE. SURVEY CODING FORM (continued)

\section{SOILS LIST}

1. Sandy loam

2. Sandy clay

3. 1 \& 2 plus some gravels

4. Sands tone bedrock

5. Above plus sandy loam

6. 4 \& 5 plus some gravels

7. Calcareous sandy clay
8. Calcareous sandy loam

9. Calcareous clay loam with some gravels

10. Redeposited sandy mud and silts

11. Small grave1s

12. Large grave1s

13. Brown sand

14: Gravels \& sandstone caliche 


\section{APPENDIX III.}

\section{SCOPE OF WORK*}

The purpose of the required survey shall be total completion of intensive survey and evaluation of the remaining 10 percent of the area to be impacted by the Choke Canyon Reservoir. The lands involved (approximately 5800 acres) include a 11 those to be acquired by the Bureau of Reclamation for possible future development of recreational facilities, as well as lands to which access areas to be surveyed are marked on Map No. 1. Detailed maps sha 11 be made available following award of contract. The subject area must be surveyed using methods compatible with previously completed research. The survey methodology recommended by those presently investigating the area is as follows (excerpted from November 1978 CAR/UTSA Draft Recommendations to the Bureau):

Surveyors should be spaced at $100 \mathrm{~m}$ intervals and follow transects set with compass sitings. Within each $100 \mathrm{~m}$ swath, surveyors should use a wide zigzag pattern to maximize coverage of each survey area. Located and defined sites should be marked with a semipermanent datum. Site limits and approximate datum locations should be recorded as accurately as possible on Bureau 2-foot contour maps. Site boundaries should be flagged in the field. Artifactual material should be collected from sites only when there is a strong likelihood of discovery by relic collectors. Otherwise, time-diagnostic artifacts and other interesting materials should be left on the site after being sketched, described and/or photographed.

Cultural manifestations in the Choke Canyon area frequently take the form of extensive scatters of artifacts of highly variable density. Accordingly, it is imperative that all those participating in a survey are working with the same definition of a "site" and that different surveys" definitions are compatible. The working definition employed by Texas Tech crews was:

.. any area of $5 \times 5 \mathrm{~m}$ which contains 10 or more artifacts, including burned/fractured 1ithic materials. Areas which do not meet the site criteria, but which have a nearsite concentration of materials are documented in field notes.

It is anticipated that:

Site definitions will be especially difficult on valley margin and upland acreage where exposed gravel deposits have been differentially exploited as a source of raw materials for lithic tool production... Ground cover conditions varying from open, cultivated fields and pastures to almost impenetrable brush may be expected (in the remaining acreage) (CAR/UTSA November 1978 Draft Recommendations).

\footnotetext{
ॠTaken from Bureau of Reclamation Solicitation No. 5B-V0527.
} 
UTSA estimates that completion of the survey utilizing the above summarized technique should involve 110-person days (a four-person crew surveying an average of 215 acres per day). 


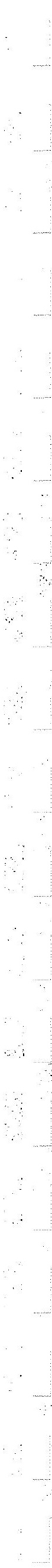

